\title{
Urban-rural differences in major mental health conditions
}

Francesca Solmi, ${ }^{1}$ Jennifer Dykxhoorn, ${ }^{1}$ James B. Kirkbride ${ }^{1 *}$

${ }^{1}$ PsyLife Research Group, Division of Psychiatry, UCL, London, W1T 7NF, UK

*Correspondence to: Dr James B Kirkbride, j.kirkbride@ucl.ac.uk

Word count: 8,395

Keywords: Schizophrenia, psychotic disorders, common mental disorders, depression, anxiety, suicide, rural-urban, epidemiology

\section{Author biographies}

Dr Francesca Solmi is a Research Associate in psychiatric epidemiology in the PsyLife group, Division of Psychiatry, UCL. She is interested in researching life course risk factors of various mental health problems in childhood, adolescence and young adulthood as well as ways to improve access to mental health services.

Jennifer Dykxhoorn is a PhD student in the PsyLife Lab, Division of Psychiatry, UCL. Her research focuses on social and spatial determinants of psychotic disorders. She has a background in public mental health policy, having previously worked for the Public Health Agency of Canada and Mental Health Commission of Canada.

Dr James Kirkbride is a Reader in Epidemiology in the Division of Psychiatry, UCL. He specialises in investigating the determinants of excess risk of schizophrenia and other psychotic disorders experienced by urban populations and ethnic minority groups. He runs the PsyLife group (www.PsyLife.eu) in the Division of Psychiatry, UCL.

\begin{abstract}
In this chapter we review the evidence for rural-urban and spatial variation of three major sets of mental health disorders: schizophrenia and related psychotic disorders; common mental disorders including depression and anxiety, and; suicide. For each, we review the recent literature which has addressed these issues and report the main strengths and limitations of the available evidence. The most consistent evidence for rural-urban gradients in mental health risk are found to exist for schizophrenia and suicide, with more mixed evidence in relation to common mental disorders. For schizophrenia and suicide we go onto review the major hypotheses that have been put forward to account for rural-urban variation in risk.
\end{abstract}




\section{Introduction}

How the social and physical environment may affect our mental health - both positively and negatively - is a topic of increasing global importance. By 2014, more than half of the world's population lived in urban areas, and this is set to rise to a staggering $66 \%$ by 2050 . In this chapter, we examine the potential mental health implications that this global shift towards living in urbanised environments may have at the population level. We have restricted our analysis to three major psychiatric conditions, where most research has been conducted: psychotic disorders, including schizophrenia; common mental disorders i.e. depression and anxiety; and suicide. We have organised the chapter into four main sections. First, we review the current evidence linking psychotic disorders to our urban environments. We identify the main hypotheses which have been proposed to explain such associations and review their plausibility, given the available evidence. We repeat this analysis for common mental disorders in Section 3, and for suicidal outcomes in Section 4. In the final section, our focus turns to consider the extent to which the evidence presented in this chapter informs possible preventive medicine strategies with respect to our urban environments.

For each mental health outcome, we have distinguished between studies which examine urban-rural differences in risk, and those which have provided more detailed examination of small area variation in the rate at which psychiatric conditions occur. These second set of studies have often sought to move beyond rural-urban dichotomies to investigate how differences in the environmental milieu of small areas - or "neighbourhoods" - within a single setting may affect the risk of mental health disorders. Such effects are typically studied using a variety of "multilevel" statistical approaches which are designed to examine whether risk factors which occur at several levels of causation, including both the individual- and neighbourhood-level - are associated with a given outcome of interest. Typically, such small areas have been defined by administrative units to investigate "neighbourhood-level" effects. While the extent to which these represent meaningful neighbourhoods as perceived by their occupants has been debated, ${ }^{1}$ small area units typically provide a more homogeneous and precise basis for analytical investigation than simpler rural-urban distinctions. Although primarily used for administrative purposes, such as Census enumeration or elections, area-level units such as postcode tracts, census wards or postal areas are often demarcated by physical barriers such as major roads, rivers or other topographical features, providing some ecological validity to their "neighbourhood" status.

The best data we have on the role cities play in shaping mental health presently come from High Income Country (HIC) settings. The paucity of data on mental health and urbanisation from Low and 
Middle Income Country (LAMIC) settings, where economic development, basic services and physical health care may present more fundamental topics for service providers and urban planners, reflects an important gap in the literature. It also presents an opportunity to carefully tailor the best available evidence on mental health and city life from other settings into policy and planning recommendations for the design of mentally healthy cities. Since it has been suggested that population dynamics and urban development trajectories will differ in LAMIC settings, ${ }^{2}$ this calls on researchers and funding bodies to invest time, energy and capital into research programs which identify the burden and correlates of psychiatric morbidity in rapidly developing populations. For this reason, in this chapter we endeavour to make special reference to any studies conducted in LAMIC settings, where pertinent and robust evidence is available.

\section{Schizophrenia and other non-affective psychoses}

Schizophrenia affects between 4.6 (range: $1.9-10.0$ ), 3.3 (range: 1.3-8.2) and 4.0 (range: $1.6-12.1$ ) people per 1000, depending on whether measured at a single point in time (point prevalence), over the course of a year (annual or period prevalence) or over the entire lifetime (lifetime prevalence) is considered. ${ }^{3}$ Incidence, which describes the number of new cases within a defined population in one year, is estimated to be appromxitely 15.2 new cases per 100,000 people per year (range: $7.7-43.0){ }^{4}$ However, incidence is heterogeneously distributed throughout the population according to several socio-demographic indicators, ${ }^{5}$ including age, sex, ethnicity and place. Schizophrenia and related disorders are more common among men, young adults (before 35 years old) and people from disadvantaged socio-economic backgrounds. ${ }^{6}$ Consistent evidence suggests that higher rates are experienced by people from minority ethnic backgrounds, most notably those of black African and black Caribbean origin living in the UK, Netherlands and elsewhere. ${ }^{7-10} \mathrm{~A}$ long history of research, beginning with the pioneering work of two Chicago sociologists Robert E.L. Faris and Warren H. Dunham in the 1930s, have shown that the distribution of the incidence of schizophrenia and other non-affective psychoses is not random, but occurs with greater-than-expected frequency in more densely populated urban settings. ${ }^{11}$ Such geographical patterning exists between countries ${ }^{12}$, within countries along a urban-rural gradient, ${ }^{13,14}$ and between neighbourhoods within urban areas. ${ }^{13}$ Over the last 70 years, spatial variation in the incidence of non-affective psychotic disorders such as schizophrenia has been replicated in a number of early ${ }^{15-17}$ and more recent studies (Tables 1 \& 2 summarise those studies published since 1990). 


\subsection{Urban vs. rural settings}

Perhaps owing to the presence of comprehensive population and hospital registers, Western Europe has provided the setting for the vast majority of the forty studies which have investigated urban-rural differences in the distribution of psychosis since 1990 (Table 1), ${ }^{5,18-46}$ with thirteen studies in Denmark, ${ }^{23-25,27,30,31,37-40,42,44,46}$ four in The Netherlands, ${ }^{21,22,32,34}$ three in Sweden, ${ }^{18,33,35}$ three in the UK, ${ }^{5,20,36}$ two in Finland, ${ }^{26,29}$ two in Ireland, ${ }^{28,41}$ one in Italy, ${ }^{19}$ one in Spain, ${ }^{45}$ and one in France ${ }^{43}$; one study was conducted in Israel. ${ }^{47}$ In comparison, research from developing countries has been more sparse. $^{48-54}$

Urbanicity has commonly been defined by grouping geographical areas from the most rural to the most urban on the basis of population density, ${ }^{21,22,35,47}$ degree of urbanization, $5,18,23-25,27,30,31,33,36-40,42-$ $44,46,50,52$ density of postal addresses ${ }^{29,32,34}$ or a dichotomised urban-rural classification. ${ }^{19,20,26,28,41,45,48,49,51,53,54}$ With the exception of an Israeli study, which measured diagnosis at military conscription, ${ }^{47}$ urbanicity has been measured at the time of diagnosis, ${ }^{5,19,24,28,32,34-36,41,43,45,48-}$ $51,53,54$ birth, ${ }^{20,23,25-27,29,30,33,37,39,40,42,44,46}$ birth and upbringing, ${ }^{22,31,52}$ birth and diagnosis, ${ }^{21}$ or upbringing only. ${ }^{18,38}$ While methods used to diagnose participants have varied (see Table 1 ), many studies used standardised clinical interviews to derive a diagnosis of schizophrenia $5,32,34,41,48,50-54$ rather than reliance solely on case records. Many studies simultaneously investigated urbanisation in relation to depression (see also Section 3), ${ }^{35,50-52}$ affective psychotic disorders (see Section 2.4), 20,22,25,28,40,43,50,53 and other non-affective psychoses. ${ }^{21,22,26,33,43,50}$ Finally, an increasing number of studies have employed longitudinal cohorts $5,18,19,21-24,26,28-31,33,35-37,39,40,42,44,46$ (which usually provide stronger, prospective evidence of an association) over other types of study design, including cross- sectional ${ }^{32,45,48,50-54}$ (more frequent in LAMIC) or case-control ${ }^{20,25,27}$ designs. Despite heterogeneity in design, populations, and definitions of urbanicity and diagnosis, all but eight studies ${ }^{19,26,29,36,49,51-54}$ found higher schizophrenia risk in urban compared with rural areas. ${ }^{5,18,20-25,27,28,30-35,37-48,50,55,56}$ Of those which did not, three reported no urban-rural differences, ${ }^{36,51,53}$ while five observed higher rates in rural areas. ${ }^{19,26,29,49,52,54}$ Summarising much of the literature from high income countries, a recent meta-analysis estimated that people living in urban areas at birth and upbringing had over twice the odds of developing schizophrenia compared with people living in rural areas (Odds Ratio [OR]: 2.37; 95\% confidence interval $[95 \% \mathrm{Cl}]: 2.01-2.81) .{ }^{57}$

Findings from nine studies conducted in LAMIC countries were less consistent than those reported from High Income countries (see Table 1). Lifetime and 12-month prevalence of schizophrenia seems to be higher in urban areas in Chile (men) ${ }^{50}$ and China,${ }^{48,55,56}$ whilst the reverse has been observed in 
Table 1: Summary of literature on rural/urban differences in the distribution of schizophrenia (from 1990 onwards, chronologically ordered)

\begin{tabular}{|c|c|c|c|c|c|c|c|c|}
\hline Study ID & $\begin{array}{l}\text { Diagnostic } \\
\text { criteria \& } \\
\text { outcome } \\
\end{array}$ & $\begin{array}{l}\text { Case } \\
\text { ascertain } \\
\text {-ment } \\
\end{array}$ & Sample size & Definition of urban & $\begin{array}{l}\text { Timing of } \\
\text { urban }\end{array}$ & Findings & Confounders & Comments \\
\hline $\begin{array}{l}\text { Lewis et a }\left.\right|^{18} \\
\text { (1992) } \\
\text { Sweden }\end{array}$ & $\begin{array}{c}\text { ICD-8 } \\
\text { (schizophrenia) }\end{array}$ & Register & $\begin{array}{l}\text { Sample }=49,191 \\
\text { (male conscripts) } \\
\text { Cases }=268\end{array}$ & Degree of urbanization & Upbringing & $\begin{array}{l}\text { Higher odds of schizophrenia in } \\
\text { men who grew up in the city }\end{array}$ & $\begin{array}{l}\text { Family finances, cannabis } \\
\text { use, psychiatric diagnosis } \\
\text { at conscription, parental } \\
\text { divorce, number of } \\
\text { friends, 'nervous' feelings, } \\
\text { family history of } \\
\text { schizophrenia. } \\
\end{array}$ & $\begin{array}{l}\text { Fully-adjusted model showed weaker } \\
\text { statistical signficiance between urban } \\
\text { \& rural risk }\end{array}$ \\
\hline $\begin{array}{l}\text { Thornicroft et al }{ }^{19} \\
\text { (1993) } \\
\text { Italy }\end{array}$ & $\begin{array}{l}\text { ICD-9 } \\
\text { (schizophrenia \& } \\
\text { other psychoses, } \\
\text { including } \\
\text { affective) }\end{array}$ & Registers & Not reported & $\underline{\text { Urban vs. rural }}$ & At diagnosis & $\begin{array}{c}\text { Higher prevalence } \& \text { incidence } \\
\text { rates in the rural compared with } \\
\text { urban areas }\end{array}$ & $\begin{array}{c}\text { Household composition, } \\
\text { employment, population } \\
\text { density, number of } \\
\text { dependents, number of } \\
\text { family members } \\
\text { economically inactive, age, } \\
\text { number of rooms per } \\
\text { person } \\
\end{array}$ & $\begin{array}{l}\text { Living alone, being unemployed, } \% \\
\text { total population who unmarried, } \\
\text { separated or divorced were } \\
\text { associated with schizophrenia in } \\
\text { urban, but nor rural area }\end{array}$ \\
\hline $\begin{array}{l}\text { Takei et al20 } \\
\text { (1995) } \\
\text { UK }\end{array}$ & $\begin{array}{c}\text { ICD-9 } \\
\text { (schizophrenia) }\end{array}$ & Registers & $\begin{array}{c}\text { Sample }=24,858 \\
\text { Cases }=6,553\end{array}$ & Urban vs. rural & Birth & $\begin{array}{c}\text { Risk of schizophrenia higher for } \\
\text { people born in urban areas \& } \\
\text { autumn/winter months }\end{array}$ & Age, sex, place of birth & $\begin{array}{l}\text { Poor control group (psychiatric } \\
\text { controls), cross-sectional data }\end{array}$ \\
\hline $\begin{array}{l}\text { Marcelis et al } 22 \\
\text { (1998) } \\
\text { The Netherlands }\end{array}$ & $\begin{array}{c}\text { ICD-9 } \\
\text { (narrow } \\
\text { schizophrenia, } \\
\text { broad } \\
\text { schizophrenia) }\end{array}$ & Registers & $\begin{array}{c}\mathrm{N}=47,721 \\
\text { Narrow } \\
\text { schizophrenia (NS) } \\
(\mathrm{N}=5606) \\
\text { Broad schizophrenia } \\
\text { (BS) (N=16716) }\end{array}$ & $\frac{\text { Urban vs. rural (based on }}{\text { population density) }}$ & $\begin{array}{c}\text { Birth \& } \\
\text { upbringing }\end{array}$ & $\begin{array}{l}\text { People with urban birth \& urban } \\
\text { exposure had higher risk of narrow } \\
\& \text { broad schizophrenia }\end{array}$ & $\begin{array}{l}\text { Birth cohort, season of } \\
\text { birth, age of onset }\end{array}$ & $\begin{array}{l}\text { High correlation between urban birth } \\
\& \text { urban exposure. Unable to test for } \\
\text { incidence among people born in } \\
\text { urban areas who moved to rural areas } \\
\text { Similar pattern for affective psychoses }\end{array}$ \\
\hline $\begin{array}{l}\text { Marcelis et al }{ }^{21} \\
\text { (1999) } \\
\text { The Netherlands) }\end{array}$ & $\begin{array}{c}\text { ICD-9 } \\
\text { (narrow } \\
\text { schizophrenia, } \\
\text { broad } \\
\text { schizophrenia) }\end{array}$ & Registers & $\begin{array}{l}\mathrm{N}=1,351,637 \\
(\mathrm{~N}=338, \text { Narrow } \\
\text { schizophrenia; } \\
\mathrm{N}=766, \text { Broad } \\
\text { schizophrenia) }\end{array}$ & $\frac{\text { Urban vs. rural (based on }}{\text { population density) }}$ & $\begin{array}{l}\text { Birth \& } \\
\text { admission }\end{array}$ & $\begin{array}{l}\text { People born in urban areas had } \\
\text { highest risk of schizophrenia. } \\
\text { People born in rural environment \& } \\
\text { admitted in urban ones were at no } \\
\text { greater risk cf. people born \& } \\
\text { admitted in rural areas } \\
\end{array}$ & & $\begin{array}{l}\text { Findings validate the hypothesis that } \\
\text { being born } \& \text { raised in urban } \\
\text { environment affects risk of } \\
\text { schizophrenia }\end{array}$ \\
\hline $\begin{array}{l}\text { Mortensen et al }{ }^{23} \\
\text { (1999) } \\
\text { Denmark }\end{array}$ & $\begin{array}{c}\text { ICD-8 } \\
\text { (schizophrenia) }\end{array}$ & Registers & $\begin{array}{l}\mathrm{N}=1,750,000 \\
(\mathrm{~N}=2,699 \text { with } \\
\text { schizophrenia) }\end{array}$ & Degree of urbanization & Birth & $\begin{array}{l}\text { Highest risk in those born in the } \\
\text { capital } c f . \text { rural area, with gradient } \\
\text { in risk by degree of urbanisation of } \\
\text { birthplace }\end{array}$ & $\begin{array}{l}\text { Age, sex, calendar month } \\
\text { at diagnosis, maternal \& } \\
\text { paternal age at child's } \\
\text { birth, family history of } \\
\text { schizophrenia }\end{array}$ & \\
\hline
\end{tabular}




\begin{tabular}{|c|c|c|c|c|c|c|c|c|}
\hline Study ID & $\begin{array}{l}\text { Diagnostic } \\
\text { criteria \& } \\
\text { outcome }\end{array}$ & $\begin{array}{l}\text { Case } \\
\text { ascertain } \\
\text {-ment }\end{array}$ & Sample size & Definition of urban & $\begin{array}{l}\text { Timing of } \\
\text { urban }\end{array}$ & Findings & Confounders & Comments \\
\hline $\begin{array}{l}\text { Eaton et al } \\
\text { (2000) } \\
\text { Denmark }\end{array}$ & $\begin{array}{c}\text { ICD } \\
\text { (schizophrenia, } \\
\text { non-affective } \\
\text { psychoses, } \\
\text { affective } \\
\text { psychosis, manic- } \\
\text { depressive } \\
\text { psychoses) }\end{array}$ & Registers & $\begin{array}{c}33,320 \text { live births at } \\
1 \text { year occurred } \\
\text { between } 1973-1977 \\
\text { (10\% random } \\
\text { sample of all live } \\
\text { births) }\end{array}$ & Degree of urbanization. & Birth & $\begin{array}{c}\text { Highest odds of schizophrenia \& } \\
\text { non-affective psychoses with urban } \\
\text { birth (capital cf. rural areas), with a } \\
\text { marked gradient by degree of } \\
\text { urbanisation. No differences by } \\
\text { urban birth status for affective } \\
\text { psychoses }\end{array}$ & $\begin{array}{c}\text { Weight for age, } \\
\text { gestational age, mother's } \\
\text { age, parity, sex, birth year }\end{array}$ & $\begin{array}{l}\text { Sample restricted to those under } 21 \\
\text { years; only about } 20 \% \text { of people will } \\
\text { have received diagnosis of a non- } \\
\text { affective psychosis by then }\end{array}$ \\
\hline $\begin{array}{l}\text { Schelin et a }{ }^{24} \\
\text { (2000) } \\
\text { Denmark }\end{array}$ & $\begin{array}{c}\text { ICD-8 } \\
\text { schizophrenia }\end{array}$ & Register & $\begin{array}{c}2,441 \text { first } \\
\text { admissions 1978-82 }\end{array}$ & Degree of urbanization & At diagnosis & $\begin{array}{c}\text { Higher incidence (direct } \\
\text { standardisation) in the capital \& } \\
\text { sub-urban areas cf. rural areas in } \\
\text { males \& females. [NB: not formally } \\
\text { tested, but } 95 \% \text { Cl do not overlap] }\end{array}$ & Age \& sex & $\begin{array}{l}\text { People in the capital had higher odds } \\
\text { of being diagnosed at the first } \\
\text { admissions in the capital, but not in } \\
\text { suburban areas cf. rural areas. }\end{array}$ \\
\hline $\begin{array}{l}\text { Suvisaari et a }{ }^{26} \\
\text { (2000) } \\
\text { Finland }\end{array}$ & $\begin{array}{l}\text { ICD-8, ICD-9 } \\
\text { schizophrenia }\end{array}$ & $\begin{array}{l}\text { Register } \\
\text { (hospital + } \\
\text { pension) }\end{array}$ & $\begin{array}{l}\text { Sample }=\text { all people } \\
\text { born } 1950-69 . \text { Cases } \\
=15,892 \text { patients } \\
\text { hospitalised } 1970-91\end{array}$ & $\underline{\text { Urban vs. rural }}$ & Birth & $\begin{array}{l}\text { Lower risk of schizophrenia in } \\
\text { urban versus rural areas }\end{array}$ & $\begin{array}{l}\text { Age, sex, month of birth, } \\
\text { birth cohort }\end{array}$ & $\begin{array}{l}\text { Only } 15-20 \% \text { of population lived in } \\
\text { urban areas over the study period. }\end{array}$ \\
\hline $\begin{array}{l}\text { Agerbo et } \mathrm{a}^{27} \\
(2001) \\
\text { Denmark }\end{array}$ & $\begin{array}{c}\text { ICD8, } \\
\text { schizophrenia }\end{array}$ & Register & $\begin{array}{l}\text { 17,604 people. (191 } \\
\text { cases admitted } \\
1981-93 \& 17,413 \\
\text { controls matched by } \\
\text { gender \& age) } \\
\end{array}$ & Degree of urbanization. & Birth & $\begin{array}{l}\text { Highest schizophrenia risk in people } \\
\text { born in the capital } c f \text {. people born } \\
\text { in rural areas, but no evidence of a } \\
\text { gradient by degree of urbanisation }\end{array}$ & $\begin{array}{l}\text { Crowding, family history } \\
\text { of schizophrenia (parents } \\
\& \text { siblings), season of birth }\end{array}$ & $\begin{array}{l}\text { Crowding not associated with } \\
\text { schizophrenia, although there might } \\
\text { be limitations in choice of } \\
\text { measurement }\end{array}$ \\
\hline $\begin{array}{l}\text { Allardyce et al28 } \\
\text { (2001) } \\
\text { Ireland }\end{array}$ & $\begin{array}{l}\text { ICD9-ICD10, } \\
\text { schizophrenia }\end{array}$ & Register & $\begin{array}{c}439 \text { cases diagnosed } \\
1979-84 \text { \& 1992-97 } \\
\text { (177 in Galloway, } \\
262 \text { in Camberwell) }\end{array}$ & $\begin{array}{l}\text { Dumfries \& Galloway, rural } \\
\text { areas. Camberwell, inner } \\
\text { city area. }\end{array}$ & At diagnosis & $\begin{array}{c}\text { Higher incidence rate ratio in } \\
\text { Camberwell cf. Dumfries \& } \\
\text { Galloway }\end{array}$ & Age, sex, time period & $\begin{array}{c}\text { Timing of exposure at diagnosis does } \\
\text { not rule out reverse causation }\end{array}$ \\
\hline $\begin{array}{l}\text { Haukka et a }{ }^{29} \\
\text { (2001) } \\
\text { Finland }\end{array}$ & $\begin{array}{l}\text { ICD8-ICD9, } \\
\text { Schizophrenia }\end{array}$ & Register & $\begin{array}{c}\text { Sample }=\text { all people } \\
\text { born } 1950-1969 . \\
\text { Cases }=14,828 \\
\text { patients hospitalised } \\
\text { before } 1992\end{array}$ & Density of postal addresses & At birth & $\begin{array}{c}\text { Higher schizophrenia risk in rural } \\
\text { areas in 1950s, higher risk in urban } \\
\text { areas in 1960s }\end{array}$ & Age, sex, birth year & \\
\hline $\begin{array}{l}\text { Pedersen et al }{ }^{10} \\
\text { (2001) } \\
\text { Denmark }\end{array}$ & $\begin{array}{c}\text { ICD-10 } \\
\text { (schizophrenia) }\end{array}$ & Register & $\begin{array}{c}\text { Sample }=2.66 \\
\text { million Danish } \\
\text { citizens born 1950- } \\
\text { 1993. Cases = 10,264 } \\
\text { people with } \\
\text { schizophrenia }\end{array}$ & Degree of urbanization. & Birth & $\begin{array}{l}\text { Schizophrenia risk highest in the } \\
\text { capital area } c f \text {. rural areas, with a } \\
\text { gradient by degree of urbanization }\end{array}$ & $\begin{array}{c}\text { Age, calendar year of } \\
\text { diagnosis, history of } \\
\text { mental illness in siblings, } \\
\text { history of mental illness in } \\
\text { parents }\end{array}$ & $\begin{array}{l}\text { Same results found for different sub- } \\
\text { groupings of population, by place \& } \\
\text { time of birth of mother }\end{array}$ \\
\hline
\end{tabular}




\begin{tabular}{|c|c|c|c|c|c|c|c|c|}
\hline Study ID & $\begin{array}{l}\text { Diagnostic } \\
\text { criteria \& } \\
\text { outcome }\end{array}$ & $\begin{array}{l}\text { Case } \\
\text { ascertain- } \\
\text { ment }\end{array}$ & Sample size & Definition of urban & $\begin{array}{l}\text { Timing of } \\
\text { urban }\end{array}$ & Findings & Confounders & Comments \\
\hline $\begin{array}{l}\text { Van Os et a }\left.\right|^{32} \\
\text { (2001) } \\
\text { The Netherlands }\end{array}$ & $\begin{array}{l}\text { DSM-III } \\
\text { (any psychotic } \\
\text { disorder, } \\
\text { narrowly \& } \\
\text { broadly defined } \\
\text { psychotic } \\
\text { symptoms) }\end{array}$ & $\begin{array}{l}\text { Survey, } \\
\text { Diagnostic } \\
\text { interview } \\
\text { (CIDI) }\end{array}$ & $\begin{array}{c}\text { Sample }=7,076 \\
\text { individuals aged } 18- \\
64 \text { years. Cases }= \\
107, \text { any psychotic } \\
\text { disorders. Psychotic } \\
\text { symptoms }=295 \\
\text { narrow definition; } \\
1,237 \text { broad } \\
\text { definition }\end{array}$ & Degree of urbanization. & At diagnosis & $\begin{array}{c}\text { Odds of reporting any outcome were } \\
\text { highest in the most urbanised areas, } \\
\text { with evidence of a gradient across } \\
\text { levels of urbanisation }\end{array}$ & $\begin{array}{l}\text { Age, sex, education, } \\
\text { country of birth of } \\
\text { participant \& parents }\end{array}$ & People born outside Finland excluded \\
\hline $\begin{array}{l}\text { Pedersen et a }{ }^{13} \\
\text { (2001a) } \\
\text { Denmark }\end{array}$ & $\begin{array}{l}\text { ICD-8, ICD-10 } \\
\text { (Schizophrenia) }\end{array}$ & Register & $\begin{array}{c}\text { Sample }=1.89 \mathrm{~m} \\
\text { Danish citizens born } \\
1956-83 .(807,000 \\
\text { born after } 1971 \text { for } \\
\text { analyses on } \\
\text { urbanicity during } \\
\text { upbringing) } \\
\text { Cases }=8,253 \\
\text { people with } \\
\text { schizophrenia } \\
(1,553 \text { born after } \\
1971)\end{array}$ & Degree of urbanization. & $\begin{array}{c}\text { Birth \& } \\
\text { upbringing }\end{array}$ & $\begin{array}{l}\text { People born in the capital had highest } \\
\text { schizophrenia risk, with evidence of } \\
\text { gradient by urbanisation. } \\
\text { Living in a higher degree of urbanisation } \\
\text { at age } 5 \text { than at birth was associated } \\
\text { with higher schizophrenia risk } c f \text {. having } \\
\text { always lived in rural areas. People living } \\
\text { in a higher or lower degree of } \\
\text { urbanization at age } 10 c f \text {. age } 5 \text { had } \\
\text { higher or lower risks }\end{array}$ & $\begin{array}{l}\text { Age, sex, calendar year, } \\
\text { history of mental health in } \\
\text { parents \& siblings }\end{array}$ & $\begin{array}{l}\text { When adjusting for urbanicity at birth } \\
\text { \& upbringing, the former was no } \\
\text { longer significantly associated with } \\
\text { schizophrenia risk, although the latter } \\
\text { was }\end{array}$ \\
\hline $\begin{array}{l}\text { Harrison et al } \\
\text { (2003) } \\
\text { Sweden }\end{array}$ & $\begin{array}{l}\text { ICD-9, ICD-10 } \\
\text { Schizophrenia, } \\
\text { other non- } \\
\text { affective } \\
\text { psychoses }\end{array}$ & Register & $\begin{array}{l}\text { Sample }=696,025 \\
\text { people born 1973- } \\
1980 . \text { Cases }=363 \\
\text { with schizophrenia, } \\
590 \text { with other non- } \\
\text { affective psychoses. }\end{array}$ & Degree of urbanization. & Birth & $\begin{array}{l}\text { Risk of non-affective psychoses, but not } \\
\text { of schizophrenia was higher for people } \\
\text { born in the main cities } \& \text { their suburbs. }\end{array}$ & $\begin{array}{l}\text { Birth weight, ponderal } \\
\text { index, birth length, } \\
\text { gestational age, season of } \\
\text { birth, age of mother, } \\
\text { APGAR score, parity, } \\
\text { caesarean section, } \\
\text { gender, mother's } \\
\text { education }\end{array}$ & $\begin{array}{c}\text { Short follow up means results are } \\
\text { generalizable only to early onset } \\
\text { cases. }\end{array}$ \\
\hline $\begin{array}{l}\text { Van Os et a }\left.\right|^{34} \\
\text { (2003) } \\
\text { The Netherlands }\end{array}$ & $\begin{array}{l}\text { DSM-III-R } \\
\text { (psychotic } \\
\text { disorder, broad } \\
\text { \& narrow } \\
\text { psychosis) }\end{array}$ & $\begin{array}{l}\text { Survey, } \\
\text { Diagnostic } \\
\text { interview } \\
\text { (CIDI) }\end{array}$ & $\begin{array}{l}\text { Sample }=7,076 \\
\text { people, cases }=915 \\
\text { with sub-clinical } \\
\text { symptoms, } 295 \\
\text { clinical symptoms, }\end{array}$ & $\underline{\text { Degree of urbanization. }}$ & At diagnosis & $\begin{array}{l}\text { Urbanicity was associated with higher } \\
\text { risk of psychotic disorder in the } \\
\text { proband \& a broadly or narrowly } \\
\text { defined psychosis in the family }\end{array}$ & $\begin{array}{c}\text { Age, sex, level of } \\
\text { education \& country of } \\
\text { birth of proband, } \\
\text { proband's mother, \& } \\
\text { proband's father \& for } \\
\text { parental history of } \\
\text { delusions or } \\
\text { hallucinations or diagnosis }\end{array}$ & $\begin{array}{l}\text { The study found a significant } \\
\text { interaction } \\
\text { between urbanicity \& family history } \\
\text { in their effects on psychotic disorder } \\
\text { in the proband. }\end{array}$ \\
\hline
\end{tabular}




\begin{tabular}{|c|c|c|c|c|c|c|c|c|}
\hline Study ID & $\begin{array}{l}\text { Diagnostic } \\
\text { criteria \& } \\
\text { outcome }\end{array}$ & $\begin{array}{l}\text { Case } \\
\text { ascertain- } \\
\text { ment }\end{array}$ & Sample size & Definition of urban & $\begin{array}{l}\text { Timing of } \\
\text { urban }\end{array}$ & Findings & Confounders & Comments \\
\hline $\begin{array}{l}\text { Byrne et al }{ }^{46} \\
\text { (2004) } \\
\text { Denmark }\end{array}$ & $\begin{array}{l}\text { ICD-8, ICD-10 } \\
\text { Schizophrenia }\end{array}$ & Registers & $\begin{aligned} \text { Sample } & =200,294 \\
\text { Cases } & =7,704\end{aligned}$ & Degree of urbanization. & At birth & $\begin{array}{l}\text { Higher incidence rate ratios of } \\
\text { schizophrenia among people born in } \\
\text { the capital, capital suburbs \& provinces } \\
\text { after adjusting for all covariates }\end{array}$ & $\begin{array}{l}\text { Occupation, education, } \\
\text { marital status. Father's } \\
\text { age at birth, death of a } \\
\text { parent prior to admission, } \\
\text { number of siblings, } \\
\text { reference to father at } \\
\text { birth, history of family } \\
\text { psychiatric illness }\end{array}$ & $\begin{array}{l}\text { Socio-economic variables measured } \\
\text { at time of diagnosis \& not at birth }\end{array}$ \\
\hline $\begin{array}{l}\text { Sundquist et al }{ }^{35} \\
\text { (2004) } \\
\text { Sweden }\end{array}$ & $\begin{array}{l}\text { ICD-9, ICD-10 (\& } \\
\text { DSM-IV) } \\
\text { Psychosis }\end{array}$ & Registers & $\begin{array}{c}\text { Sample }=4.4 \mathrm{~m} \\
\text { Swedish people } \\
\text { aged } 25-64 \text { years on } \\
31 / 12 / 1999(35,727 \\
\text { people excluded as } \\
\text { they had a previous } \\
\text { admission) } \\
\text { Cases }=6,160\end{array}$ & $\frac{\text { Quintiles of population }}{\underline{\text { density }}}$ & At diagnosis & $\begin{array}{l}\text { Psychosis risk highest for both men \& } \\
\text { women in most urbanised quintile, with } \\
\text { some evidence of a dose response } \\
\text { relationship }\end{array}$ & $\begin{array}{l}\text { Marital status, education, } \\
\text { immigrant status, age } \\
\text { (stratified by gender) }\end{array}$ & $\begin{array}{l}\text { Similar association found for } \\
\text { depression, but not as strong }\end{array}$ \\
\hline $\begin{array}{l}\text { Allardyce et al }{ }^{36} \\
\text { (2005) } \\
\text { Scotland, UK }\end{array}$ & $\begin{array}{c}\text { ICD-9 } \\
\text { (schizophrenia) }\end{array}$ & Registers & $\begin{array}{c}\text { Sample/cases }= \\
5,838 \text { cases with } \\
\text { hospital admission } \\
\text { 1989-1993 }\end{array}$ & Degree of urbanization. & At diagnosis & $\begin{array}{l}\text { No differences in schizophrenia risk by } \\
\text { degree of urbanicity }\end{array}$ & $\begin{array}{l}\text { Social fragmentation, } \\
\text { material deprivation }\end{array}$ & $\begin{array}{c}\text { Higher levels of social fragmentation } \\
\text { were associated with higher risk of } \\
\text { schizophrenia }\end{array}$ \\
\hline $\begin{array}{l}\text { Kirkbride et al } \\
\text { (2006) } \\
\text { UK }\end{array}$ & DSM-IV & $\begin{array}{l}\text { Population } \\
\text { based case } \\
\text { finding, } \\
1997-9 \\
\end{array}$ & $\begin{array}{c}\text { Sample and cases = } \\
568 \\
\text { (209 cases of } \\
\text { schizophrenia) } \\
\end{array}$ & $\begin{array}{l}\frac{\text { Southeast London (Most }}{\text { Urban), Nottinghamshire }} \\
\text { \& Bristol (Least Urban) }\end{array}$ & At diagnosis & $\begin{array}{l}\text { Higher incidence of schizophrenia in } \\
\text { London cf. Nottingham \& Bristol }\end{array}$ & Age, sex, ethnicity & $\begin{array}{l}\text { Similar distribution found for } \\
\text { affective psychoses }\end{array}$ \\
\hline $\begin{array}{l}\text { Pedersen et al }{ }^{37} \\
\text { (2006) } \\
\text { Denmark }\end{array}$ & $\begin{array}{l}\text { ICD-8, ICD-10 } \\
\text { (schizophrenia) }\end{array}$ & Register & $\begin{array}{l}\text { Sample }=711,897 \\
\text { people born 1956-86 } \\
\text { alive at age 15; } \\
\text { Cases = 2,720 with } \\
\text { schizophrenia } \\
\text { between 1970-2000 }\end{array}$ & Degree of urbanization. & $\begin{array}{l}\text { Birth, birth } \\
\text { of sibling, } \\
\text { age } 15\end{array}$ & $\begin{array}{l}\text { People born in capital areas had higher } \\
\text { schizophrenia risk cf. those born in rural } \\
\text { areas, regardless of older sibling place } \\
\text { of birth. Among people born in rural } \\
\text { areas, some evidence that having an } \\
\text { older sibling born in the capital } \\
\text { increased schizophrenia }\end{array}$ & $\begin{array}{l}\text { Age, sex, calendar year, } \\
\text { parental age, history of } \\
\text { mental health in parents } \\
\text { or siblings }\end{array}$ & $\begin{array}{l}\text { Study suggests that some of the } \\
\text { causes of schizophrenia due to the } \\
\text { environment are rooted in families }\end{array}$ \\
\hline $\begin{array}{l}\text { Pedersen \& } \\
\text { Mortensen } \\
\text { (2006a) Denmark }\end{array}$ & $\begin{array}{l}\text { ICD-8, ICD-10 } \\
\text { (schizophrenia) }\end{array}$ & Register & $\begin{array}{l}\text { Sample }=1.89 \mathrm{~m} \\
\text { people born } 1956- \\
83 ; \text { Cases }=10,755 \\
\text { people with } \\
\text { schizophrenia }\end{array}$ & Degree of urbanization. & $\begin{array}{l}\text { Upbringing } \\
\left(15^{\text {th }}\right. \\
\text { birthday) }\end{array}$ & $\begin{array}{l}\text { People living in the capital city had } \\
\text { greatest risk of developing } \\
\text { schizophrenia, with some evidence of a } \\
\text { gradient across levels of urbanisation }\end{array}$ & $\begin{array}{c}\text { Sex, calendar year, } \\
\text { distance from main road } \\
\text { \& mental illness in parent } \\
\text { or sibling }\end{array}$ & $\begin{array}{l}\text { Distance from main road was no } \\
\text { longer significant when model } \\
\text { adjusted for degree of urbanisation }\end{array}$ \\
\hline
\end{tabular}




\begin{tabular}{|c|c|c|c|c|c|c|c|c|}
\hline Study ID & $\begin{array}{l}\text { Diagnostic } \\
\text { criteria \& } \\
\text { outcome }\end{array}$ & $\begin{array}{l}\text { Case } \\
\text { ascertain- } \\
\text { ment }\end{array}$ & Sample size & Definition of urban & $\begin{array}{l}\text { Timing of } \\
\text { urban }\end{array}$ & Findings & Confounders & Comments \\
\hline $\begin{array}{l}\text { Pedersen }^{39} \\
\text { (2006b) Denmark }\end{array}$ & $\begin{array}{l}\text { ICD-8, ICD-10 } \\
\text { (schizophrenia) }\end{array}$ & Register & $\begin{array}{c}\text { Sample }=5.05 \mathrm{~m} \\
\text { people born } \\
\text { between } 1910-86 \\
\text { cases }=23,051 \text { cases } \\
\text { diagnosed } 1970- \\
2001\end{array}$ & Degree of urbanization. & Birth & $\begin{array}{l}\text { Urbanisation associated with greater } \\
\text { schizophrenia risk in the youngest, but } \\
\text { not oldest age cohort }\end{array}$ & Age \& sex & \\
\hline $\begin{array}{l}\text { Laursen et al }{ }^{40} \\
\text { (2007) } \\
\text { Denmark }\end{array}$ & $\begin{array}{l}\text { ICD-8, ICD-10 } \\
\text { (schizophrenia) }\end{array}$ & Register & $\begin{array}{c}\text { Sample = } 2 \text { million } \\
\text { people born 1955- } \\
\text { 1978; cases = 13,297 } \\
\text { between 1973-2001 } \\
\end{array}$ & Degree of urbanization. & Birth & $\begin{array}{l}\text { People born in urban areas had twice } \\
\text { the schizophrenia risk than those born } \\
\text { in rural areas }\end{array}$ & & \\
\hline $\begin{array}{l}\text { Weiser et al }{ }^{47} \\
(2007) \\
\text { Israel }\end{array}$ & $\begin{array}{c}\text { ICD-10 } \\
\text { (schizophrenia) }\end{array}$ & Register & $\begin{array}{l}\text { Sample }=371,603 \\
\text { conscripts age } 16- \\
17 ; \text { Cases }=1,174\end{array}$ & Degree of urbanization. & $\begin{array}{l}\text { At military } \\
\text { conscription }\end{array}$ & $\begin{array}{l}\text { Increasing population density } \\
\text { corresponded to increasing } \\
\text { schizophrenia risk (linear trend) }\end{array}$ & Age, vulnerability \& SES. & $\begin{array}{l}\text { Male only sample. Effect more } \\
\text { pronounced in "vulnerable" sample }\end{array}$ \\
\hline $\begin{array}{l}\text { Kelly et al }{ }^{41}(2010) \\
\text { Ireland }\end{array}$ & $\begin{array}{c}\text { DSM-III-R } \\
\text { (schizophrenia, } \\
\text { other psychotic } \\
\text { illness) }\end{array}$ & $\begin{array}{l}\text { Diagnostic } \\
\text { interview } \\
\text { (SCID) }\end{array}$ & $\begin{array}{l}\text { Sample } / \text { cases }=324 \\
\text { schizophrenia }\end{array}$ & $\underline{\text { Urban vs. rural }}$ & At diagnosis & $\begin{array}{l}\text { People living in Dublin had twice the } \\
\text { risk of developing schizophrenia } c f . \\
\text { people living in rural countries }\end{array}$ & Age, sex, SES, ethnicity & \\
\hline $\begin{array}{l}\text { Sorensen et al }{ }^{42} \\
\text { (2014) } \\
\text { Denmark }\end{array}$ & $\begin{array}{l}\text { ICD-8, ICD-10 } \\
\text { (schizophrenia) }\end{array}$ & Register & $\begin{array}{c}\text { Sample }=2.49 \mathrm{~m} \\
\text { people born } 1955- \\
93 ; \text { Cases }=17,389 \\
\text { between } 1970-2005\end{array}$ & Degree of urbanization. & Birth & $\begin{array}{c}\text { People living in the capital area had } \\
\text { greatest schizophrenia risk, with some } \\
\text { evidence of a gradient across levels of } \\
\text { urbanisation } \\
\end{array}$ & $\begin{array}{l}\text { Age, sex, calendar year, } \\
\text { parental history of mental } \\
\text { illness, parental loss, } \\
\text { immigration, parental age }\end{array}$ & \\
\hline $\begin{array}{l}\text { Szoke et al }{ }^{43} \\
\text { (2014) } \\
\text { France }\end{array}$ & $\begin{array}{c}\text { DSM-IV } \\
\text { (non-affective } \\
\text { psychoses, } \\
\text { affective } \\
\text { psychoses) } \\
\end{array}$ & $\begin{array}{l}\text { Reported by } \\
\text { public \& } \\
\text { private } \\
\text { services }\end{array}$ & $\begin{array}{c}\text { Sample }=246,773 \\
\text { (age } 18-64 \text { residing } \\
\text { in catchment area \& } \\
\text { diagnosed with } \\
\text { schizophrenia) } \\
\end{array}$ & 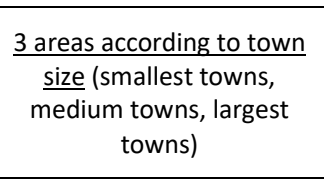 & At diagnosis & $\begin{array}{l}\text { People living in the largest towns had } \\
\text { higher risk for both affective \& non- } \\
\text { affective psychoses }\end{array}$ & Age \& sex & $\begin{array}{l}\text { Risk for non-affective psychoses in } \\
\text { largest towns was greater than that } \\
\text { for affective psychoses. }\end{array}$ \\
\hline $\begin{array}{l}\text { Vassos et al }{ }^{44} \\
\text { (2015) } \\
\text { Denmark }\end{array}$ & $\begin{array}{c}\text { ICD-10 } \\
\text { (schizophrenia) }\end{array}$ & Register & $\begin{array}{c}\text { Sample }=2,894,640 \\
\text { born } 1995-2012 \\
\text { Cases }=13,702 \\
\end{array}$ & Degree of urbanization. & Birth & $\begin{array}{l}\text { Higher incidence of schizophrenia } \\
\text { among people born in the capital cf. } \\
\text { rural areas. Evidence of a dose- } \\
\text { response }\end{array}$ & $\begin{array}{c}\text { Calendar period, age \& } \\
\text { sex, parental age at birth, } \\
\text { family history of mental } \\
\text { illness } \\
\end{array}$ & $\begin{array}{c}\text { Higher incidence of affective } \\
\text { psychoses among people born in the } \\
\text { capital vs. rural areas, but no dose- } \\
\text { response }\end{array}$ \\
\hline $\begin{array}{l}\text { Moreno-Kunster } \\
\text { et al }{ }^{45}(2016) \\
\text { Spain }\end{array}$ & $\begin{array}{c}\text { ICD-10 } \\
\text { (schizophrenia) }\end{array}$ & Register & $\begin{array}{c}\text { Sample }=1,663 \\
\text { Cases }=1,052\end{array}$ & Urban vs Rural & At diagnosis & $\begin{array}{l}\text { Higher schizophrenia rates in urban } \\
\text { areas }\end{array}$ & None & No confounders included in analyses \\
\hline
\end{tabular}




\begin{tabular}{|c|c|c|c|c|c|c|c|c|}
\hline Study ID & $\begin{array}{l}\text { Diagnostic } \\
\text { criteria \& } \\
\text { outcome } \\
\end{array}$ & $\begin{array}{c}\text { Case } \\
\text { ascertain- } \\
\text { ment }\end{array}$ & Sample size & Definition of urban & $\begin{array}{l}\text { Timing of } \\
\text { urban }\end{array}$ & Findings & Confounders & Comments \\
\hline \multicolumn{9}{|l|}{ LAMIC } \\
\hline $\begin{array}{l}\text { Ganguli49 } \\
\text { (2000) } \\
\text { India }\end{array}$ & $\begin{array}{l}\text { ICD \& DSM } \\
\text { (unspecified) } \\
\text { Schizophrenia }\end{array}$ & Multiple* & $\begin{array}{l}\text { Review of } 15 \text { studies } \\
\text { across Indian regions }\end{array}$ & $\underline{\text { Urban vs rural }}$ & At diagnosis & $\begin{array}{c}\text { Higher prevalence of } \\
\text { schizophrenia in rural } c f \text {. urban } \\
\text { areas }\end{array}$ & Multiple* & $\begin{array}{l}\text { Differences between urban \& rural } \\
\text { prevalence not tested statistically }\end{array}$ \\
\hline $\begin{array}{l}\text { Vicente et a }{ }^{50} \\
(2006) \\
\text { Chile }\end{array}$ & $\begin{array}{l}\text { DSM-III-R } \\
\text { Non-affective } \\
\text { psychosis }\end{array}$ & $\begin{array}{c}\text { Survey, } \\
\text { Diagnostic } \\
\text { interview } \\
\text { (CIDI) }\end{array}$ & $\begin{array}{l}\text { Sample }=2,978 \\
\text { people }\end{array}$ & Urban vs rural & At diagnosis & $\begin{array}{l}\text { Prevalence of non-affective } \\
\text { psychoses lowest in area with } \\
\text { greatest \% rural population }\end{array}$ & $\begin{array}{l}\text { Age, sex, education, marital } \\
\text { status, income }\end{array}$ & $\begin{array}{l}\text { Urban-rural areas not directly } \\
\text { compared }\end{array}$ \\
\hline $\begin{array}{l}\text { Wei et al } \\
\text { (2008) } \\
\text { Tibet }\end{array}$ & $\begin{array}{c}\text { DSM-IV } \\
\text { Schizophrenia }\end{array}$ & SCID-I & $\begin{array}{c}\text { Sample }=5,145 \\
\text { Cases }=\text { N/A }\end{array}$ & Urban vs rural & At diagnosis & $\begin{array}{c}\text { No significant differences between } \\
\text { urban \& rural areas }\end{array}$ & - & No multivariable analysis \\
\hline $\begin{array}{l}\text { Xiang et a }\left.\right|^{48} \\
\text { (2008) } \\
\text { China }\end{array}$ & Schizophrenia & CIDI & $\begin{array}{c}\text { Sample }=5,926 \\
\text { Cases }=0.49 \% \text { of the } \\
\text { sample }\end{array}$ & $\underline{\text { Urban vs rural }}$ & At diagnosis & $\begin{array}{l}\text { Higher odds of schizophrenia in } \\
\text { urban areas after adjustment for } \\
\text { confounders }\end{array}$ & $\begin{array}{l}\text { Age, sex, marital status, } \\
\text { education, employment, } \\
\text { income, smoking status, family } \\
\text { history of schizophrenia }\end{array}$ & \\
\hline $\begin{array}{l}\text { Lundberg et al }{ }^{52} \\
\text { (2009) } \\
\text { Uganda }\end{array}$ & $\begin{array}{l}\text { Psychotic } \\
\text { symptoms }\end{array}$ & $\begin{array}{l}\text { Interview } \\
\text { (PDI-21) }\end{array}$ & Sample $=646$ & Urban, semi-urban, rural & $\begin{array}{l}\text { Birth \& } \\
\text { upbringing }\end{array}$ & $\begin{array}{l}\text { People born in urban areas had } \\
\text { higher odds of having psychotic } \\
\text { symptoms }\end{array}$ & $\begin{array}{l}\text { Age, sex, education, marital } \\
\text { status, SES, family history of } \\
\text { psychiatric disorders }\end{array}$ & $\begin{array}{l}\text { Small sample, findings could be due } \\
\text { to chance }\end{array}$ \\
\hline $\begin{array}{l}\text { Phillips et al } \\
\text { (2009) } \\
\text { China }\end{array}$ & $\begin{array}{c}\text { DSM-IV } \\
\text { Schizophrenia }\end{array}$ & $\begin{array}{l}\text { Screening } \\
\text { with GHQ } \\
\text { followed up } \\
\text { by SCID } \\
\text { interview }\end{array}$ & $\begin{array}{c}\text { Sample }=63,004 \\
\text { Cases }=2 \%\end{array}$ & $\underline{\text { Urban vs rural }}$ & At diagnosis & $\begin{array}{c}\text { No differences in odds of } \\
\text { schizophrenia in urban \& rural } \\
\text { areas }\end{array}$ & $\begin{array}{l}\text { Data were adjusted for design } \\
\text { factors \& clustering. Post- } \\
\text { stratified to the sampling } \\
\text { frame }\end{array}$ & $\begin{array}{l}\text { No confounders included in } \\
\text { analyses }\end{array}$ \\
\hline $\begin{array}{l}\text { Song et al }{ }^{54} \\
(2009) \\
\text { China }\end{array}$ & $\begin{array}{c}\text { CCMD } \\
\text { Schizophrenia }\end{array}$ & $\begin{array}{l}\text { Screening } \\
\text { (unspecified) } \\
\text { followed by } \\
\text { interview }\end{array}$ & $\begin{array}{c}\text { Sample }=294,356 \\
\text { Age }=22-29\end{array}$ & $\underline{\text { Urban vs rural }}$ & At diagnosis & $\begin{array}{l}\text { Lower odds of schizophrenia in } \\
\text { urban } c f . \text { rural populations }\end{array}$ & $\begin{array}{l}\text { Sex, birth cohort (pre-during, } \\
\text { post-famine) }\end{array}$ & $\begin{array}{l}\text { Study refers to period of the famine } \\
\text { of } 1959-61 \text {. Generalisability to } \\
\text { other contexts might be limited }\end{array}$ \\
\hline $\begin{array}{l}\text { Long et a }{ }^{56} \\
\text { (2014) } \\
\text { China }\end{array}$ & Schizophrenia & Multiple* & $\begin{array}{l}\text { Meta-analysis of } 52 \\
\text { studies }\end{array}$ & Urban vs rural & At diagnosis & $\begin{array}{l}\text { Higher prevalence in urban } c f . \\
\text { rural dwellers }\end{array}$ & Heterogeneous across studies & \\
\hline $\begin{array}{l}\text { Chan et al55 } \\
\text { (2015) } \\
\text { China }\end{array}$ & Schizophrenia & Multiple* & $\begin{array}{l}\text { Review of } 42 \\
\text { prevalence studies }\end{array}$ & Urban vs rural & At diagnosis & $\begin{array}{l}\text { Higher prevalence in urban } c f . \\
\text { rural dwellers }\end{array}$ & Heterogeneous across studies & $\begin{array}{l}\text { Differences between urban \& rural } \\
\text { prevalence not tested statistically }\end{array}$ \\
\hline
\end{tabular}


India, ${ }^{49}$ and the Chinese famine study, ${ }^{54}$ where rural populations experienced greatest levels of malnutrition. Other studies, including those from Tibet, ${ }^{51}$ Uganda $^{52}$ and China ${ }^{53}$ have found equivocal prevalence between urban and rural populations. Of the eight studies which did not find observe higher schizophrenia rates in more urban areas, 5 were were conducted in LAMIC settings, ${ }^{48,49,52-54}$ meaning only 4 of 9 LAMIC studies (44.4\%) observed this phenomenon, ${ }^{48,50,55,56}$ compared with 28 out of 31 (90.3\%) studies in HIC settings; this difference was strongly statistically significant $\left(\mathrm{Chi}^{2}\left[\mathrm{X}^{2}\right]\right.$ test; $p=0.002 ;$ Table 1). At present it is not possible to determine the reason for this difference; on the one hand the composition and risk profiles of people living in rural and urban settings in LAMIC settings may be very different to those in HICs, while on the other hand, methodological limitations of some studies from LAMIC settings (see below) may explain this difference. In general, these issues include the validity of definitions of urban exposure used, $^{50}$ small sample sizes, ${ }^{52}$ absences in statistical testing ${ }^{49,58}$ or failure to use appropriate regression models. ${ }^{51}$ This may limit the validity and generalizability of these results, despite exceptions which have employed large sample sizes and robust statistical models to investigate urban-rural differences. ${ }^{48,54}$

\subsection{Neighbourhoods}

The majority of the studies which have investigated the spatial distribution of schizophrenia at finergrained, small area "neighbourhood-levels" have been conducted in Europe $e^{8,9,16,59-76}$ (9 in the UK, ${ }^{8,9,59,60,62,65-67,70,71}$ four in The Netherlands, ${ }^{61,63,68,75}$ three in Sweden, ${ }^{64,69,76}$ two in Ireland, ${ }^{73,74}$ one in Italy, ${ }^{72}$ and one in Germany ${ }^{16}$ with a minority undertaken in Israel, ${ }^{77}$ South Africa ${ }^{78}$ and the United States). ${ }^{79}$ Most studies employed hospital or early intervention services registers to identify cases of schizophrenia, $8,9,16,59-64,69,70,74,76-78$ or to identify a 'screened' population to further interview with clinical instruments, ${ }^{65-68,71-73,75}$ and only one study employed a survey design. ${ }^{79}$ Neighbourhood of residence was generally defined based upon administrative units at the time of diagnosis ${ }^{8,9,16,59-68,70-}$ 75,77-79 or, more rarely, upbringing (Table 2). ${ }^{69,76}$

These ecological and multilevel studies have suggested that up to $12 \%$ of variance in the distribution of schizophrenia could be explained by neighbourhood characteristics, ${ }^{61,64,66,69}$ although further work is required here; this pattern may vary by degree of urbanicity (higher in more urban areas $5,18,20-$ 25,27,28,30-35,37-48,50,55,56), and most studies, despite limited exceptions, ${ }^{69,76}$ have not examined other potential causal levels such as the role of the family or school environment.

Indicators of area socioeconomic deprivation, such as overcrowding, ${ }^{9}$ housing tenure, ${ }^{61,73,79}$ unemployment ${ }^{9,60,61,63,64,66-74,78,79}$ and social/welfare benefits ${ }^{61,69,79}$ have extensively been used in the 
Table 2: Summary of literature on neighbourhood differences in the distribution of schizophrenia (from 1990 onwards, chronologically ordered)

\begin{tabular}{|c|c|c|c|c|c|c|c|c|c|}
\hline $\begin{array}{l}\text { Study ID \& } \\
\text { Setting }\end{array}$ & $\begin{array}{l}\text { Diagnostic } \\
\text { Criteria \& } \\
\text { outcome }\end{array}$ & $\begin{array}{l}\text { Case finding, } \\
\text { age range, } \\
\text { years }\end{array}$ & $\begin{array}{l}\text { Sample size } \\
\text { \& cases }\end{array}$ & $\begin{array}{c}\text { Definition of } \\
\text { neighbourhood }\end{array}$ & $\begin{array}{l}\text { Timing of } \\
\text { exposure }\end{array}$ & Area-levels measures & $\begin{array}{l}\text { Individual- } \\
\text { level } \\
\text { measures }\end{array}$ & Findings & Comments \\
\hline \multicolumn{10}{|c|}{ High income countries } \\
\hline $\begin{array}{l}\text { Dauncey et al }{ }^{59} \\
\text { (1993) } \\
\text { UK }\end{array}$ & Schizophrenia & $\begin{array}{l}\text { Psychiatric registers } \\
\text { (age 15-54 years, } \\
\text { 1978-80) }\end{array}$ & $\begin{array}{c}\text { Cases }=67 \\
\text { schizophrenia }\end{array}$ & $\begin{array}{l}5 \text { enumeration } \\
\text { districts } \\
\text { (Nottingham) }\end{array}$ & $\begin{array}{l}\text { Birth, } \\
\text { upbringing, } \\
\text { diagnosis, } \\
\text { follow up }\end{array}$ & Deprivation & $\begin{array}{l}\text { Age, sex, } \\
\text { ethnicity }\end{array}$ & $\begin{array}{l}\text { Of } 67 \text { cases, } 27 \text { were borb in the inner city. } \\
23 \text { out of these } 27 \text { were born in council } \\
\text { estates/deprived areas. Over half of the } \\
\text { Nottingham-born were in deprived areas } 5 \\
\text { years before \& after diagnosis }\end{array}$ & $\begin{array}{l}\text { Small sample } \\
\text { limits validity of } \\
\text { findings }\end{array}$ \\
\hline $\begin{array}{l}\text { Loffler et al }{ }^{16} \\
\text { (1999) } \\
\text { Germany }\end{array}$ & $\begin{array}{c}\text { ICD-9 } \\
\text { (Schizophrenia) }\end{array}$ & $\begin{array}{l}\text { Psychiatric registers } \\
\text { (age 12-59 years; } \\
\text { 1987-89) }\end{array}$ & $\begin{array}{l}\text { Cases }=276 \\
\text { incident } \\
\text { schizophrenia }\end{array}$ & $\begin{array}{l}23 \text { districts in } \\
\text { Mannheim, } 14 \text { in } \\
\text { Heidelberg }\end{array}$ & At diagnosis & $\begin{array}{l}\text { Measure of segregation \& } \\
\text { population density }\end{array}$ & - & $\begin{array}{l}\text { Highest admission rates in inner city areas } \\
\text { with high population density \& segregation }\end{array}$ & $\begin{array}{l}\text { Ecological study } \\
\text { could not } \\
\text { separate role of } \\
\text { area \& individual }\end{array}$ \\
\hline $\begin{array}{l}\text { Croudace et al } \\
\text { (2000) } \\
\text { UK }\end{array}$ & $\begin{array}{l}\text { ICD-10 } \\
\text { (admissions \& } \\
\text { first episode } \\
\text { schizophrenia) }\end{array}$ & $\begin{array}{l}\text { Hospital registers } \\
\text { (ages } 16-64 \text { years, } \\
\text { all admissions } 1992- \\
\text { 3, first episode } \\
\text { 1992-4) }\end{array}$ & $\begin{array}{l}\text { Cases }=1208 \\
\text { admissions; } 168 \\
\text { first episode }\end{array}$ & $\begin{array}{l}104 \text { Electoral wards } \\
\text { (Nottingham) }\end{array}$ & $\begin{array}{c}\text { At } \\
\text { admissions }\end{array}$ & Social deprivation & Age \& sex & $\begin{array}{l}\text { Higher incidence } \& \text { admissions for } \\
\text { psychosis in areas with above-average } \\
\text { social deprivation }\end{array}$ & $\begin{array}{l}\text { Non-linear } \\
\text { association }\end{array}$ \\
\hline $\begin{array}{l}\text { Van Os et al }{ }^{11} \\
\text { (2000) } \\
\text { The Netherlands }\end{array}$ & $\begin{array}{c}\text { ICD-9 } \\
\text { (Schizophrenia) }\end{array}$ & $\begin{array}{l}\text { Psychiatric } \\
\text { registers } \\
\text { (all ages, 1986-97) }\end{array}$ & $\begin{array}{l}\text { Sample }=\sim \\
120,000 \\
\text { inhabitants } \\
\text { Cases }=220\end{array}$ & $\begin{array}{l}35 \text { neighbourhoods } \\
\text { in Maastricht } \\
(120,000 \\
\text { inhabitants). } \\
\text { Traditional and } \\
\text { sociological entities }\end{array}$ & At diagnosis & $\begin{array}{c}\% \text { men, } \% \text { single } / \text { married, } \% \\
\text { under age } 25 . \% \text { of } \\
\text { population: on rental } \\
\text { support, non-voters, welfare } \\
\text { dependent, foreign born, } \\
\text { unemployed, mobility, new } \\
\text { housing } \\
\end{array}$ & $\begin{array}{l}\text { Age, sex, marital } \\
\text { status, }\end{array}$ & $\begin{array}{l}12 \% \text { of variance in schizophrenia incidence } \\
\text { at neighbourhood-level. \% single/divorced } \\
\text { men associated with higher schizophrenia } \\
\text { risk. Higher risk of schizophrenia for single } \\
\text { men living in areas with fewer single men }\end{array}$ & \\
\hline $\begin{array}{l}\text { Boydell et al9 } \\
\text { (2001) } \\
\text { UK }\end{array}$ & $\begin{array}{l}\text { ICD-9, ICD-10 } \\
\text { (schizophrenia) }\end{array}$ & $\begin{array}{l}\text { Psychiatric registers } \\
\text { (all ages, 1988-97) }\end{array}$ & $\begin{array}{c}\text { Sample }=\sim \\
120,000 \\
\text { inhabitants } \\
\text { Cases }=222 \\
\end{array}$ & $\begin{array}{l}15 \text { electoral wards } \\
\text { in Camberwell, } \\
\text { London }\end{array}$ & At diagnosis & $\begin{array}{l}\% \text { non-white ethnic } \\
\text { minority, deprivation }\end{array}$ & $\begin{array}{l}\text { Age, sex, } \\
\text { ethnicity }\end{array}$ & $\begin{array}{c}\text { Significant differences in incidence } \\
\text { between neighbourhoods. Higher rates in } \\
\text { non-white ethnic minorities as \% non-white } \\
\text { ethnic inhabitants decreased }\end{array}$ & \\
\hline $\begin{array}{l}\text { Silver et al }{ }^{79} \\
\text { (2002) } \\
\text { USA }\end{array}$ & $\begin{array}{c}\text { DSM-III } \\
\text { (schizophrenia) }\end{array}$ & $\begin{array}{l}\text { Survey, Diagnostic } \\
\text { interview (DIS) } \\
\text { (age 18-96 years) }\end{array}$ & $\begin{array}{l}\text { Sample }= \\
11,686 \text { survey } \\
\text { respondents }\end{array}$ & $\begin{array}{l}261 \text { census tracts } \\
\text { across New Haven, } \\
\text { CT, Baltimore, MD, } \\
\text { St. Louis, MO, } \\
\text { Durham, NC, and } \\
\text { Los Angeles, CA } \\
\end{array}$ & At diagnosis & $\begin{array}{l}\text { Index consisting of several } \\
\text { measures of poverty, social } \\
\text { isolation \& residential } \\
\text { turnover }\end{array}$ & $\begin{array}{l}\text { Age, sex, } \\
\text { ethnicity, } \\
\text { household } \\
\text { income, years of } \\
\text { education, } \\
\text { marital status } \\
\end{array}$ & $\begin{array}{l}\text { Higher schizophrenia risk in women \& with } \\
\text { less education, lower income, single marital } \\
\text { status \& neighbourhoods with higher } \\
\text { turnover \& disadvantage; association } \\
\text { disappeared after adjustment for SES }\end{array}$ & \\
\hline $\begin{array}{l}\text { Boydell et al62 } \\
(2004) \\
\text { UK }\end{array}$ & $\begin{array}{c}\text { Unspecified } \\
\text { (schizophrenia) }\end{array}$ & $\begin{array}{l}\text { Psychiatric registers } \\
\qquad(1988-97)\end{array}$ & 222 cases & $\begin{array}{l}15 \text { electoral wards in } \\
\text { Camberwell, London }\end{array}$ & At diagnosis & $\begin{array}{c}\text { \% non-white ethnic } \\
\text { minorities, deprivation, } \\
\text { inequality }\end{array}$ & $\begin{array}{c}\text { Age, sex, } \\
\text { individual } \\
\text { ethnicity } \\
\end{array}$ & $\begin{array}{l}\text { Inequality only associated with higher rates } \\
\text { of schizophrenia in most deprived areas }\end{array}$ & \\
\hline
\end{tabular}




\begin{tabular}{|c|c|c|c|c|c|c|c|c|c|}
\hline $\begin{array}{l}\text { Study ID \& } \\
\text { Setting }\end{array}$ & $\begin{array}{l}\text { Diagnostic } \\
\text { Criteria \& } \\
\text { outcome } \\
\end{array}$ & $\begin{array}{l}\text { Case finding, } \\
\text { age range, } \\
\text { years }\end{array}$ & $\begin{array}{l}\text { Sample size } \\
\text { \& cases }\end{array}$ & $\begin{array}{c}\text { Definition of } \\
\text { neighbourhood }\end{array}$ & $\begin{array}{l}\text { Timing of } \\
\text { exposure }\end{array}$ & Area-levels measures & $\begin{array}{l}\text { Individual- } \\
\text { level } \\
\text { measures }\end{array}$ & Findings & Comments \\
\hline $\begin{array}{l}\text { Drukker et al }{ }^{63} \\
\text { (2006) } \\
\text { The Netherlands }\end{array}$ & $\begin{array}{c}\text { DSM-IV } \\
\text { (schizophrenia) }\end{array}$ & $\begin{array}{l}\text { Psychiatric registers } \\
\text { (all ages, 1993- } \\
\text { 2002) }\end{array}$ & $\begin{array}{l}98 \text { cases } / 3369 \\
\text { controls }\end{array}$ & $\begin{array}{l}36 \text { districts in } \\
\text { Maastricht }\end{array}$ & At diagnosis & $\begin{array}{l}\text { Informal social control, } \\
\text { social cohesion \& trust, } \\
\text { socioeconomic deprivation }\end{array}$ & $\begin{array}{l}\text { Age, sex, } \\
\text { education, SES, } \\
\text { marital status, } \\
\text { education, } \\
\text { employment \& } \\
\text { living conditions }\end{array}$ & $\begin{array}{l}\text { Low social cohesion \& trust, high levels of } \\
\text { residential instability associated with } \\
\text { higher treated incidence of schizophrenia. } \\
\text { Associations no longer significant after } \\
\text { adjustment for SES }\end{array}$ & $\begin{array}{l}\text { Social capital } \\
\text { obtained from } \\
\text { questionnaire } \\
\text { sent to sample of } \\
\text { residents in each } \\
\text { district (48\% } \\
\text { response) } \\
\end{array}$ \\
\hline $\begin{array}{l}\text { Lofors et al }{ }^{64} \\
\text { (2007) } \\
\text { Sweden }\end{array}$ & $\begin{array}{l}\text { ICD-9/ICD-10 } \\
\text { (psychosis) }\end{array}$ & $\begin{array}{l}\text { Psychiatric registers } \\
\text { (incident cases) } \\
\text { (age 25-64 years; } \\
\text { 1997-9) }\end{array}$ & $\begin{array}{l}\text { Sample }=4.5 \mathrm{~m} \\
\text { Swedish } \\
\text { citizens. Cases = } \\
10,930\end{array}$ & $\begin{array}{l}\text { Clusters of small } \\
\text { area units }(\sim 2,000 \\
\text { residents each in } \\
\text { Stockholm, } 1,000 \text { in } \\
\text { the rest of the } \\
\text { country) }\end{array}$ & At diagnosis & $\begin{array}{l}\text { Linking social capital (voting } \\
\text { participation), } \\
\text { neighbourhood deprivation }\end{array}$ & $\begin{array}{l}\text { Sex, age, housing } \\
\text { tenure, } \\
\text { education, } \\
\text { marital status, } \\
\text { employment, } \\
\text { country of birth }\end{array}$ & $\begin{array}{l}\text { Low social capital \& neighbourhood } \\
\text { deprivation associated with high rates of } \\
\text { psychoses, even after adjustment for } \\
\text { individual level characteristics }\end{array}$ & $\begin{array}{l}\text { Individual } \\
\text { characteristics } \\
\text { explain the whole } \\
\text { association for } \\
\text { depression }\end{array}$ \\
\hline $\begin{array}{l}\text { Kirkbride et al }{ }^{66} \\
\text { (2007) } \\
\text { UK }\end{array}$ & $\begin{array}{l}\text { ICD-10 } \\
\text { (schizophrenia, } \\
\text { non-affective } \\
\text { psychoses) }\end{array}$ & $\begin{array}{l}\text { Clinical interview } \\
\text { for cases identified } \\
\text { in hospital registers } \\
\text { [SCAN] (age 16-64 } \\
\text { years, 1997-9) }\end{array}$ & $\begin{array}{l}\text { Sample }=2001 \\
\text { census ward } \\
\text { population } \\
\text { Cases }=218 \text { non } \\
\text { affective } \\
\text { psychosis } \\
\end{array}$ & $\begin{array}{l}33 \text { wards in South- } \\
\text { East London } \\
\text { (Lambeth and } \\
\text { Southwark, } 6000 \\
\text { residents in each } \\
\text { area) } \\
\end{array}$ & At diagnosis & $\begin{array}{l}\text { Population density, ethnic } \\
\text { density, ethnic } \\
\text { fragmentation, deprivation, } \\
\text { voter turnout }\end{array}$ & $\begin{array}{l}\text { Age, sex, } \\
\text { ethnicity }\end{array}$ & $\begin{array}{l}\text { Low social capital (measured by voting } \\
\text { turnout) associated with higher rates of } \\
\text { psychosis, even after adjusting for } \\
\text { individual-level variables. Lower ethnic } \\
\text { fragmentation associated with lower rates }\end{array}$ & \\
\hline $\begin{array}{l}\text { Kirkbride et al }{ }^{65} \\
\text { (2007a) } \\
\text { UK }\end{array}$ & $\begin{array}{l}\text { ICD-10 } \\
\text { (schizophrenia, } \\
\text { non-affective } \\
\text { psychoses) }\end{array}$ & $\begin{array}{l}\text { Clinical interview } \\
\text { for cases identified } \\
\text { in hospital registers } \\
\text { [SCAN] (age 16-64 } \\
\text { years, 1997-9) }\end{array}$ & $\begin{array}{l}\text { Sample }=2001 \\
\text { census ward } \\
\text { population } \\
\text { Cases }=294 \\
(218 \text { non- } \\
\text { affective; } 76 \\
\text { affective } \\
\text { psychosis) }\end{array}$ & $\begin{array}{l}33 \text { wards in South- } \\
\text { East London } \\
\text { (Lambeth and } \\
\text { Southwark, } 6000 \\
\text { residents in each } \\
\text { area) }\end{array}$ & At diagnosis & & $\begin{array}{l}\text { Age, sex, } \\
\text { ethnicity }\end{array}$ & $\begin{array}{c}\text { Incidence of broadly defined psychosis \& } \\
\text { non-affective psychosis followed non- } \\
\text { random geographical distribution after } \\
\text { accounting for individual-level variables. } \\
12 \% \text { of variance explained at } \\
\text { neighbourhood level }\end{array}$ & $\begin{array}{l}\text { Pattern not } \\
\text { observed for } \\
\text { affective } \\
\text { psychosis, but } \\
\text { small sample }\end{array}$ \\
\hline $\begin{array}{l}\text { Kirkbride et al }{ }^{67} \\
\text { (2008) } \\
\text { UK }\end{array}$ & $\begin{array}{c}\text { ICD-10 } \\
\text { (schizophrenia) }\end{array}$ & $\begin{array}{l}\text { Clinical interview } \\
\text { for cases identified } \\
\text { in hospital registers } \\
\text { [SCAN] (1997-1999 } \\
\text { age 16-64) }\end{array}$ & $\begin{array}{l}\text { Sample }=2001 \\
\text { census ward } \\
\text { population } \\
\text { Cases }=148 \\
\text { schizophrenia }\end{array}$ & $\begin{array}{l}33 \text { wards in South- } \\
\text { East London } \\
\text { (Lambeth and } \\
\text { Southwark, } 6000 \\
\text { residents in each } \\
\text { area) } \\
\end{array}$ & At diagnosis & $\begin{array}{l}\text { Social cohesion \& trust, } \\
\text { social disorganisation, ethnic } \\
\text { density, ethnic } \\
\text { fragmentation, } \\
\text { socioeconomic deprivation }\end{array}$ & $\begin{array}{l}\text { Age, sex, } \\
\text { ethnicity }\end{array}$ & $\begin{array}{c}\text { Evidence of non-linear (U-shaped) } \\
\text { association between social cohesion \& } \\
\text { trust and incidence of schizophrenia. No } \\
\text { evidence of role for social disorganisation. } \\
\text { Lower ethnic fragmentation associated } \\
\text { with lower rates }\end{array}$ & $\begin{array}{l}\text { Social capital } \\
\text { measured 5-9 } \\
\text { years after } \\
\text { admissions. }\end{array}$ \\
\hline $\begin{array}{l}\text { Werner et al }{ }^{77} \\
\text { (2007) } \\
\text { Israel }\end{array}$ & $\begin{array}{c}\text { ICD-9 } \\
\text { (schizophrenia) }\end{array}$ & $\begin{array}{l}\text { Psychiatric registers } \\
\text { (incident cases) } \\
\text { (individuals born } \\
\text { 1964-76; followed } \\
\text { until 1997) }\end{array}$ & $\begin{array}{c}\text { Sample }= \\
68,794 \text { people } \\
\text { born \& living in } \\
\text { Jerusalem } \\
\text { Cases }=520\end{array}$ & $\begin{array}{l}24 \text { areas }(\sim 2,900 \\
\text { residents in each } \\
\text { area) }\end{array}$ & At diagnosis & $\begin{array}{l}\text { Area-level SES index from } \\
\text { multiple indicators }\end{array}$ & $\begin{array}{l}\text { Age, sex, father's } \\
\text { age \& ethnicity, } \\
\text { occupational } \\
\text { prestige status, } \\
\text { parental } \\
\text { education, }\end{array}$ & $\begin{array}{l}\text { Lower area-level SES associated with higher } \\
\text { schizophrenia rates after adjustment for } \\
\text { individual-level SES }\end{array}$ & \\
\hline
\end{tabular}




\begin{tabular}{|c|c|c|c|c|c|c|c|c|c|}
\hline $\begin{array}{l}\text { Study ID \& } \\
\text { Setting }\end{array}$ & $\begin{array}{l}\text { Diagnostic } \\
\text { Criteria \& } \\
\text { outcome }\end{array}$ & $\begin{array}{l}\text { Case finding, } \\
\text { age range, years }\end{array}$ & $\begin{array}{l}\text { Sample size } \\
\text { \& cases }\end{array}$ & $\begin{array}{c}\text { Definition of } \\
\text { neighbourhood }\end{array}$ & $\begin{array}{l}\text { Timing of } \\
\text { exposure }\end{array}$ & Area-levels measures & $\begin{array}{c}\text { Individual- } \\
\text { level } \\
\text { measures }\end{array}$ & Findings & Comments \\
\hline $\begin{array}{l}\text { Veiling et al }{ }^{68} \\
\text { (2008) } \\
\text { The Netherlands }\end{array}$ & $\begin{array}{l}\text { DSM-IV } \\
\text { (all psychotic } \\
\text { disorders) }\end{array}$ & $\begin{array}{l}\text { Clinical interview for } \\
\text { cases identified in } \\
\text { hospital registers } \\
\text { (CASH) } \\
\text { (age 15-54 years } \\
\text { 1997-1999, 2000- } \\
\text { 2005) }\end{array}$ & $\begin{array}{l}\text { Sample }=\text { whole } \\
\text { population, } \\
\text { Cases }=466\end{array}$ & $\begin{array}{l}44 \text { neighbourhoods } \\
\text { in The Hague ( } \max \\
38,000 \text { inhabitant } \\
\text { per neighbourhood) }\end{array}$ & At diagnosis & $\begin{array}{c}\text { Socioeconomic } \\
\text { deprivationethnic density }\end{array}$ & $\begin{array}{c}\text { Ethnicity } \\
\text { age, sex, marital } \\
\text { status, ethnicity }\end{array}$ & $\begin{array}{l}\text { Higher incidence of psychotic disorders in } \\
\text { immigrants in low ethnic density } \\
\text { neighbourhoods. No differences between } \\
\text { native Dutch residents \& immigrants in } \\
\text { high ethnic density neighbourhoods }\end{array}$ & $\begin{array}{l}\text { Outcome used } \\
\text { might conceal } \\
\text { differences } \\
\text { between affective } \\
\& \text { non-affective } \\
\text { psychoses }\end{array}$ \\
\hline $\begin{array}{l}\text { Zammit et al }{ }^{69} \\
\text { (2010) Sweden }\end{array}$ & $\begin{array}{l}\text { ICD-8, ICD-9, } \\
\text { ICD-10 } \\
\text { (schizophrenia, } \\
\text { non-affective } \\
\text { psychoses, } \\
\text { affective } \\
\text { psychoses) }\end{array}$ & $\begin{array}{l}\text { Psychiatric registers } \\
\text { (individuals born in } \\
\text { Sweden born 1972- } \\
77 \text { at age 16, } \\
\text { followed up until } \\
\text { 2003) }\end{array}$ & $\begin{array}{c}\text { Sample }= \\
169,910, \\
\text { Cases = } 881 \text { any } \\
\text { non-affective } \\
\text { psychoses; } 355 \\
\text { affective } \\
\text { psychoses }\end{array}$ & $\begin{array}{l}1,264 \text { Schools, } 284 \\
\text { municipalities, } 24 \\
\text { counties in Sweden }\end{array}$ & Upbringing & $\begin{array}{l}\text { School-level= average: } \\
\text { foreign born, social } \\
\text { fragmentation, low grade. } \\
\text { Municipality = urbanicity, } \\
\text { population density, index of } \\
\text { social fragmentation } \\
\text { (residential mobility, voting, } \\
\% \text { married/single } \\
\text { households) }\end{array}$ & $\begin{array}{c}\text { Sex, country of } \\
\text { birth, parental } \\
\text { history of } \\
\text { psychosis, change } \\
\text { of residence } \\
\text { between } 8 / 16 \\
\text { years, parental } \\
\text { SES, education, } \\
\text { family income, } \\
\text { marital status, } \\
\text { school grade }\end{array}$ & $\begin{array}{l}\text { 1) Higher risk of non-affective psychoses in } \\
\text { urban } c f \text {. rural areas explained by school- } \\
\text { level social fragmentation \& population } \\
\text { density } \\
\text { 2) Only social fragmentation remained } \\
\text { associated with non-affective psychosis risk } \\
\text { after control for individual variables }\end{array}$ & $\begin{array}{l}2.2 \% \text { of variance } \\
\text { explained at } \\
\text { neighbourhood } \\
\text { level }\end{array}$ \\
\hline $\begin{array}{l}\text { Schofield et al } \\
\text { (2011) } \\
\text { UK }\end{array}$ & $\begin{array}{l}\text { Non-organic } \\
\text { psychosis } \\
\text { (excluding drug- } \\
\text { induced ones) }\end{array}$ & $\begin{array}{c}\text { Primary care } \\
\text { database (age } 16 \text { to } \\
74 \text { years) }\end{array}$ & $\begin{array}{l}\text { Sample }=185 \\
827 \text { patients } \\
\text { Cases }=277 \\
\text { patients with } \\
\text { FEP }\end{array}$ & Postcode areas & At Diagnosis & $\begin{array}{l}\text { Area deprivation, ethnic } \\
\text { density }\end{array}$ & Age, sex, ethnicity & $\begin{array}{l}\text { FEP rates in people of black ethnicity } \\
\text { increased in neighbourhoods with lower } \\
\text { own-group ethnic density. Deprivation } \\
\text { associated with greater FEP rates }\end{array}$ & $\begin{array}{l}\text { Some evidence of } \\
\text { a dose-response } \\
\text { effect between } \\
\text { ethnic density \& } \\
\text { FEP rates }\end{array}$ \\
\hline $\begin{array}{l}\text { Bhavsar et al70 } \\
\text { (2014) } \\
\text { UK }\end{array}$ & $\begin{array}{l}\text { OPCRIT ananlysis } \\
\text { to obtain RDC } \\
\text { first episode } \\
\text { schizophrenia }\end{array}$ & $\begin{array}{l}\text { Hospital records } \\
\text { (age 16-35 years, } \\
2000-2007 \text { ) }\end{array}$ & $\begin{array}{l}\text { Sample }= \\
267,000 \\
\text { Lambeth } \\
\text { residents Cases } \\
=405\end{array}$ & $\begin{array}{l}177 \text { Super output } \\
\text { areas ( } \sim 1,100- \\
1,700 \text { residents) }\end{array}$ & At diagnosis & $\begin{array}{l}\text { Deprivation, ethnic group } \\
\text { density, population density }\end{array}$ & $\begin{array}{l}\text { Age, sex, } \\
\text { ethnicity, SES }\end{array}$ & $\begin{array}{l}\text { Higher area-level deprivation associated } \\
\text { with increase in schizophrenia incidence, } \\
\text { after adjusting for all other factors }\end{array}$ & \\
\hline $\begin{array}{l}\text { Kirkbride et al }{ }^{71} \\
\text { (2014) } \\
\text { UK }\end{array}$ & $\begin{array}{l}\text { DSM-IV } \\
\text { (first episode } \\
\text { non-affective } \\
\text { and affective } \\
\text { psychoses) }\end{array}$ & $\begin{array}{l}\text { Clinical interview for } \\
\text { cases identified in } \\
\text { hospital registers } \\
\text { [SCAN] (18-64 years, } \\
\text { 1996-1998 City \& } \\
\text { Hackney; } 1998-2000 \\
\text { in Newham and } \\
\text { Tower Hamlet) }\end{array}$ & $\begin{array}{l}\text { Sample }=2001 \\
\text { census } \\
\text { population; } \\
\text { cases = 484 } \\
\text { first episode } \\
\text { psychosis }\end{array}$ & $\begin{array}{l}56 \text { neighbourhoods } \\
\text { in East London } \\
\text { boroughs of City \& } \\
\text { Hackney, Newham, } \\
\text { and Tower Hamlets }\end{array}$ & At diagnosis & $\begin{array}{l}\text { Deprivation, inequality, } \\
\text { population density, own } \\
\text { group ethnic density, own } \\
\text { group ethnic separation, } \\
\text { social fragmentation }\end{array}$ & $\begin{array}{l}\text { Age at contact, } \\
\text { ethnicity, social } \\
\quad \text { class }\end{array}$ & $\begin{array}{l}\text { Deprivation, inequality and population } \\
\text { density were independently associated } \\
\text { with increased incidence of non-affective } \\
\text { psychosis after adjustment for individual } \\
\text { level variables. No interaction between } \\
\text { inequality and deprivation. }\end{array}$ & $\begin{array}{l}\text { Evidence of higher } \\
\text { rates of } \\
\text { schizophrenia in } \\
\text { neighbourhoods } \\
\text { with low ethnic } \\
\text { density }\end{array}$ \\
\hline $\begin{array}{l}\text { Lasalvia et al,72 } \\
\text { (2014) Italy }\end{array}$ & $\begin{array}{l}\text { ICD-10 } \\
\text { (all psychoses, } \\
\text { affective and } \\
\text { non-affective) }\end{array}$ & $\begin{array}{l}\text { SCAN to individuals } \\
\text { age } 15-54 \text { screened } \\
\text { positive for a } \\
\text { possible FEP }\end{array}$ & $\begin{array}{c}\text { Cases }=558 \\
\text { cases (441 non- } \\
\text { affective, } 117 \\
\text { affective } \\
\text { psychosis) }\end{array}$ & $\begin{array}{l}198 \text { municipalities in } \\
\text { Region Veneto }\end{array}$ & At diagnosis & $\begin{array}{c}\text { Population density, } \\
\text { neighbourhood deprivation }\end{array}$ & $\begin{array}{l}\text { Age, sex, } \\
\text { immigration } \\
\text { status }\end{array}$ & $\begin{array}{l}\text { Non-affective incidence rates were twice as } \\
\text { high in the most deprived areas vs. other } \\
\text { areas; no differences by population } \\
\text { density }\end{array}$ & $\begin{array}{l}\text { No differences for } \\
\text { affective } \\
\text { psychoses }\end{array}$ \\
\hline
\end{tabular}




\begin{tabular}{|c|c|c|c|c|c|c|c|c|c|}
\hline $\begin{array}{l}\text { Study ID \& } \\
\text { Setting }\end{array}$ & $\begin{array}{l}\text { Diagnostic } \\
\text { Criteria \& } \\
\text { outcome } \\
\end{array}$ & $\begin{array}{l}\text { Case finding, } \\
\text { age range, } \\
\text { years }\end{array}$ & $\begin{array}{l}\text { Sample size } \\
\text { \& cases }\end{array}$ & $\begin{array}{c}\text { Definition of } \\
\text { neighbourhood }\end{array}$ & $\begin{array}{l}\text { Timing of } \\
\text { exposure }\end{array}$ & Area-levels measures & $\begin{array}{c}\text { Individual- } \\
\text { level } \\
\text { measures }\end{array}$ & Findings & Comments \\
\hline $\begin{array}{l}\text { Omer et al }{ }^{73} \\
\text { (2014) } \\
\text { Ireland }\end{array}$ & $\begin{array}{l}\text { DSM-IV } \\
\text { (first episode } \\
\text { psychosis) }\end{array}$ & $\begin{array}{l}\text { Clinical interview } \\
\quad \text { for cases } \\
\text { identified in } \\
\text { hospital registers } \\
\text { (age 16+ years, } \\
\text { 1995-2007) }\end{array}$ & $\begin{array}{c}\text { Sample = } \\
199,139 \\
\text { residents in } \\
2002 . \\
\text { Cases = } 132 \\
\text { non-affective; } \\
123 \text { affective } \\
\text { psychoses } \\
\end{array}$ & $\begin{array}{l}155 \text { electoral } \\
\text { divisions in Cavan \& } \\
\text { Monaghan counties } \\
\quad \text { (Ireland) }\end{array}$ & At diagnosis & $\begin{array}{l}\text { Material deprivation, social } \\
\text { fragmentation, urbanicity }\end{array}$ & Age \& sex & $\begin{array}{l}\text { Association between deprivation \& higher } \\
\text { incidence of psychoses }\end{array}$ & $\begin{array}{l}\text { Effect may have } \\
\text { been in women } \\
\text { only. } \\
\text { First study in an } \\
\text { entirely rural } \\
\text { setting }\end{array}$ \\
\hline $\begin{array}{l}\text { Sariaslan et al }{ }^{76} \\
\text { (2015) Sweden }\end{array}$ & $\begin{array}{l}\text { ICD-9, ICD-10 } \\
\text { (schizophrenia) }\end{array}$ & $\begin{array}{c}\text { Register } \\
\text { (people born } \\
\text { 1967-1989 } \\
\text { followed up from } \\
\text { age 15 to 2009) }\end{array}$ & $\begin{array}{l}\text { Sample }= \\
2,361,585 \text { in } \\
\text { Sweden }\end{array}$ & $\begin{array}{l}\text { Small area } \\
\text { neighbourhood } \\
\text { units, excluding }<50 \\
\text { people }(\sim 1,000 \\
\text { residents each) }\end{array}$ & Upbringing & $\begin{array}{l}\text { Population density, } \\
\text { neighbourhood deprivation }\end{array}$ & $\begin{array}{l}\text { Sex, birth year, } \\
\text { birth order }\end{array}$ & $\begin{array}{c}\text { Higher schizophrenia rates in areas with } \\
\text { greater population density \& deprivation. } \\
\text { Partially mediated by unobserved familial } \\
\text { characteristics; disappeared when } \\
\text { investigating association within familial } \\
\text { nuclei } \\
\end{array}$ & \\
\hline $\begin{array}{l}\text { Veling et a }\left.\right|^{75} \\
\text { (2015) } \\
\text { The Netherlands }\end{array}$ & $\begin{array}{l}\text { DSM-IV } \\
\text { (FEP) }\end{array}$ & $\begin{array}{l}\text { Clinical interview } \\
\text { for cases } \\
\text { identified in } \\
\text { hospital registers } \\
\text { (CASH) } \\
\text { (age 15-54 years, } \\
\text { 1997-9, 2000-5) } \\
\end{array}$ & $\begin{array}{l}\text { Sample }= \\
277,008 \\
\text { residents in } \\
2005 \\
\text { Cases }=611\end{array}$ & $\begin{array}{l}42 \text { of } 44 \\
\text { neighbourhoods in } \\
\text { The Hague }\end{array}$ & At diagnosis & $\begin{array}{c}\text { Social disorganisation } \\
\text { domains = socio-economic } \\
\text { level, residential mobility, } \\
\text { ethnic diversity, \% single } \\
\text { person households, \% voter } \\
\text { turnout at local elections, } \\
\text { population density, crime }\end{array}$ & Age, sex, ethnicity & $\begin{array}{l}\text { All area level indicators showed association } \\
\text { with schizophrenia incidence initially, but } \\
\text { after mutual adjustment only association } \\
\text { with crime level remained significant }\end{array}$ & \\
\hline $\begin{array}{l}\text { O'Donoghue et } \\
\text { al }^{74} \\
(2016) \\
\text { Ireland }\end{array}$ & $\begin{array}{l}\text { DSM-IV } \\
\text { (FEP) }\end{array}$ & $\begin{array}{l}\text { SCID-I for DSM-IV } \\
\text { in early } \\
\text { intervention } \\
\text { settings } \\
\text { (between 2006- } \\
\text { 10, aged 16-65 } \\
\text { years) }\end{array}$ & $\begin{array}{l}\text { Cases }=292 \mathrm{FEP} \\
\text { participants }\end{array}$ & $\begin{array}{l}139 \text { electoral } \\
\text { divisions (median } \\
\text { 2,386 inhabitants } \\
\text { per neighbourhood) }\end{array}$ & At diagnosis & $\begin{array}{l}\text { Social Deprivation (using } \\
\text { Haase-Pratschke index); } \\
\text { unemployment; social } \\
\text { fragmentation; social } \\
\text { capital; population density }\end{array}$ & $\begin{array}{l}\text { Age, sex, marital } \\
\text { status, DUP, co- } \\
\text { morbid substance } \\
\text { use, functioning, } \\
\text { family history of } \\
\text { psychosis }\end{array}$ & $\begin{array}{l}\text { FEP rate higher in neighbourhoods with } \\
\text { greater social fragmentation \& deprivation, } \\
\text { and lower social capital. } \\
\text { DUP greater in neighbourhoods with } \\
\text { greater social fragmentation }\end{array}$ & \\
\hline \multicolumn{10}{|l|}{ LAMIC } \\
\hline $\begin{array}{l}\text { Burns et al }{ }^{78} \\
\text { (2008) } \\
\text { South Africa }\end{array}$ & $\begin{array}{l}\text { DSM-IV } \\
\text { (first episode } \\
\text { psychosis) }\end{array}$ & $\begin{array}{c}\text { Psychiatric } \\
\text { registers, } \\
\text { (incident cases) } \\
\text { (age 15-49, 2005) }\end{array}$ & $\begin{array}{c}\text { Sample }= \\
508,275 \text { from } \\
2001 \text { census } \\
\text { population; } \\
\text { cases }=160\end{array}$ & $\begin{array}{l}7 \text { municipalities, in } \\
\text { District } \\
\text { Umgungundlovu }\end{array}$ & At diagnosis & $\begin{array}{l}\text { Poverty \& inequality indices, } \\
\text { urbanicity (\% urban } \\
\text { population) }\end{array}$ & $\begin{array}{l}\text { Age, sex, } \\
\text { ethnicity, } \\
\text { employment } \\
\text { status }\end{array}$ & $\begin{array}{l}\text { Positive correlation between inequality \& } \\
\text { FEP incidence after adjustment for } \\
\text { individual-level characteristics. No } \\
\text { significant correlation between poverty \& } \\
\text { FEP incidence }\end{array}$ & \\
\hline
\end{tabular}

List of abbreviations: CAS= Census Area Statistics; CASH= Comprehensive Assessment of Symptoms and History; DIS; DSM = Diagnostic and Statistical Manual of Mental Disorder; FEP = First Episode of Psychosis; ICD= International Classification of Disease; LSOA = Lower Super Output Area; OPCRIT = operational criteria; QMPA = Questionnaire for Adult Psychiatric Morbidity; SCAN = Schedules for Clinical Assessment in Neuropsychiatry; SCID = Structured Clinical Interview for DSM Disorders; $c f$. = compared with; SES = socioeconomic status; LAMIC = low and middle income country; DUP = duration of untreated psychosis 
Literature, either individually ${ }^{61}$ or in combined indices. ${ }^{8,9,16,59,60,62-64,66-79}$ Although the plethora of measures used, and inclusion of different individual- and area-level variables, makes direct comparison of findings difficult, evidence of an association between measures of absolute deprivation at the neighbourhood level and higher risk of schizophrenia has been consistently observed. ${ }^{59,60,62,68-}$ 70,72-74,77-79 Researchers have recently become increasingly interested in the role of relative deprivation, with higher schizophrenia rates reported in neighbourhoods with greater inequality. ${ }^{62,71,78}$ As further discussed in Section 2.5, it has been hypothesised that exposure to deprivation and inequality may lead to psychosocial stresses arising from perceptions of exclusion, threat and mistrust, which in turn lead to the onset of psychotic symptoms. ${ }^{70}$

Subsequently, this has led researchers to investigate how neighbourhood-level social capital affects psychosis risk. Social capital refers to the amount of "resources [...] embedded within an individual's social network" ${ }^{81}$ (p. 911) (i.e. structural social capital), as well as social cohesion (i.e. cognitive social capital ${ }^{81,82}$ ), which taps into the presence of shared social norms, values and belonging within a community. Although developing routine measures to operationalise these potentially nebulus constructs within the field of psychiatric epidemiology remains a challenge, studies which have measured social cohesion have shown that higher levels are associated with positive mental health outcomes. ${ }^{83}$ Studies which have investigated this directly in relation to psychotic disorders have used various proxy markers of social cohesion, including voter turnout, ${ }^{61,64,66,69,75}$ the proportion of the population engaging in voluntary work, ${ }^{74}$ and direct measures of social cohesion and trust via population surveys. ${ }^{63,67}$ Evidence to support an association between social cohesion and schizophrenia is mixed, with positive findings from some studies, ${ }^{64,66,74}$ but not others, ${ }^{61,63,69,75}$ following adjustment for other individual- and area-level risk factors. One study reported a non-linear association between social cohesion and trust and schizophrenia rates, ${ }^{67}$ with higher rates in areas with low or high levels of social cohesion (compared with areas with medium levels). Thus, although neighbourhood-level social capital may be associated with schizophrenia, further research is required to investigate this in more detail.

A related concept of social fragmentation, first tested by Faris and Dunham ${ }^{11}$, has also been considered in relation to the incidence of psychotic disorders in urban areas. Social fragmentation has been heterogeneously operationalised in the literature, but can perhaps be thought of as indexing the absence of the social building blocks which would lead to the formation of social capital. Several neighbourhood-level markers of this broad construct have been investigated in relation to psychosis incidence, including the proportion of single persons, ${ }^{61,69,71,75}$ proportion of rented households (as an 
indicator of housing turnover and therefore transience $)^{71,79}$ and residential mobility. ${ }^{61,69,71,75,79}$ These measures have been associated with greater schizophrenia rates, in some, ${ }^{61,69}$ but not all studies, ${ }^{71,75,79}$ with some evidence they may be driven by individual-level social isolation rather than its neighbourhood corollary. ${ }^{75}$

Ethnic density - the proportion of someone's own ethnic group in their neighbourhood - may represent a further ethnicity-specific construct of social fragmentation. Ethnic density may underpin a range of social processes, including the extent to which there are opportunities in your residential neighbourhood to develop ties and bonds with other people who may share similar migration histories, cultures, religious beliefs, values, norms, customs, conventions and modes of behaviour. The association between ethnic density and schizophrenia risk was first observed by Faris and Dunham, ${ }^{11}$ and has subsequently been observed in various settings, where the relative risk for ethnic minority groups (compared with the majority population) is reduced as one's own-group ethnic density becomes greater at the neighbourhood level. ${ }^{6-68,71}$ Further research from Kirkbride et al. ${ }^{71}$ has extended this construct to consider the specific spatial patterning of ethnic groups within a community, which he has termed ethnic fragmentation. This research has revealed independent effects of both ethnic density and fragmentation on subsequent rates of non-affective psychotic disorders. ${ }^{66,67,71} \mathrm{~A}$ recent systematic review concluded that ethnic density may be protective against several adverse mental health outcomes, not limited to schizophrenia. ${ }^{84}$ The authors suggest ethnic density could act as a buffer towards negative social experiences (such as racism and discrimination) by promoting resilience. Living in socio-demographically and socio-economically homogeneous areas could also promote a stronger sense of identity and self-esteem in turn reducing experiences of conflict in social interactions. ${ }^{84}$

\subsection{Strengths and limitations}

Findings of higher rates of schizophrenia in urban areas and in some neighbourhoods compared with others are consistent in the schizophrenia literature across a number of study designs (e.g. longitudinal vs. cross-sectional, or register-based studies vs. surveys), populations (e.g., service users, general population), settings (including various European countries and the USA) and sample sizes, suggesting that these results are unlikely to have arisen by chance. The increasing number of studies measuring urbanicity at birth also provides evidence that urban exposures early in life could be a risk factor for schizophrenia. 
Despite these considerable advantages, there are a number of limitations which research have yet to fully address. For instance, while cohort studies which use large - often national - population registers can provide powerful, longitudinal information on a large number of individuals, the breadth of data they can include is typically narrower, often restricted to routine administrative sources. Whilst these studies can account for several important socio-demographic indicators (e.g., age, gender, parental age, country of birth, income, education), measures of area deprivation, obstetric complications and history of family mental illness, data on other individual-level characteristics may not always be available, including ethnicity, ${ }^{85-87}$ traumatic life events, ${ }^{88-90}$ substance use ${ }^{91,92}$ or markers of genetic vulnerability, although novel approaches are being developed. ${ }^{76}$ Efforts to disentangle the possibility that associations between urban living and psychosis risk are due to other, unmeasured factors, including the role of genes, as well as neighbourhood studies employing residence at birth are still required.

\subsection{A note on the affective psychoses}

Curiously, the relationship between psychotic disorders and the urban environment appears to be specific to non-affective psychotic disorder, with no robust evidence that the affective psychoses, including bipolar disorder with psychotic features and psychotic depression, share such environmental correlates, despite a shared genetic predisposition. ${ }^{93,94}$ The balance of evidence with respect to affective psychoses, including analyses of urban birth using national register data, suggests that there are few differences in incidence rates between urban and rural areas. ${ }^{25,71,95-97}$ Only three studies have observed higher rates of affective psychoses in urban areas compared with rural ones, $5,22,43$ and the magnitude of this association was smaller than observed for non-affective psychoses, while these studies only presented basic control for possible confounding factors (e.g., age, sex, ethnicity). Further research here is warranted, particularly as there is some evidence that non-psychotic affective disorders (such as depression) may vary by urban-rural environments (see Section 3). Finally, it is possible that the urban environment acts at the symptom- rather than disorder-level; in a study of people with ICD-10-confirmed first episode psychosis (including affective psychoses), Oher et al ${ }^{98}$ observed that the urban environment was most strongly associated with positive symptoms (specifically hallucinations) and depressive symptoms.

\subsection{Main Hypotheses}

In this section we review the evidence in support of the main hypotheses concerning the association between urban residency and later risk of schizophrenia and other non-affective psychoses. 


\subsubsection{Individual (intra-generational) social drift}

People who experience psychotic disorder usually have a lower socioeconomic status compared with their parents or peers who do not experience disorder. As proposed by Goldberg and Morrison, ${ }^{99}$ this may result in the drift of people both socially and spatially into more deprived, urban or less socially desirable neighbourhoods, particularly into more deprived and fragmented parts of inner cities, for which there is some evidence. ${ }^{100}$ Furthermore, studies which have investigated urban living close to the time of onset cannot exclude this possibility. $9,11,15-17,19,24,28,32,34-36,41,43,50,60,61,63,64,66-68,70,71,73,75,77-79,97$ Nonetheless, the individual social drift hypothesis cannot explain the association between urban birth or upbringing and later psychosis risk. 18,20-23,25-27,29-33,37,39,40,42 Further, a recent study by Kirkbride et al ${ }^{101}$ found that the spatial patterning of people classified as "At-Risk Mental States" for psychosis was more similar to that of first episode of psychosis (FEP) participants than of healthy controls, suggesting that those who go onto develop frank psychosis may be exposed to adverse social environments prior to a full psychotic episode. Confirmation of the existence of social and spatial drift would not preclude the possibility that aspects of the urban environment remain causally relevant to psychosis onset; indeed the two may coagulate to increase risk still further in the lead-up to disorder.

\subsubsection{Intergenerational social drift}

An interesting hypothesis to emerge more recently posits that drift could occur intergenerationally. ${ }^{38,102}$ According to this idea, which encompasses the more formal notion of geneenvironment correlation - families with an underlying vulnerability to psychosis may drift into lower socioeconomic positions and environments over time, even though frank psychosis may not reveal itself for several generations. Central to this hypothesis is that underlying genetic or environmental insults result in subclinical endophenotypes associated with non-affective psychoses, which compromise typical neurodevelopment or cognitive processes which subsequently inhibit people's upward social mobility relative to their peers across a range of domains including education, employment and social domains. While these traits may never lead to frank psychosis in a given generation, accumulated genetic and environmental insults may eventually trigger psychosis several generations later. Thus the apparent association between urban exposure and psychosis in the index case may be more readily explained by intergenerational drift, occurring via either gene- environment correlation or environment-environment correlation. It may be both an active and passive process. In the active form successive generations gradually drift into lower socioeconomic positions or more marginal neighbourhoods, whereas in the passive form, such groups remain in approximately the same social position, but unaffected families around them, over generations, exhibit a trend for upward social mobility. In a recent Swedish study, associations between population density, 
neighbourhood deprivation and the incidence of schizophrenia were partially mediated by unobserved familiar risk factors and disappeared within nuclear families, ${ }^{76}$ suggesting intergenerational drift may explain some of the association between risk and urban living. The current evidence, however, is limited and intergenerational social drift will be difficult to detect.

\subsubsection{Antenatal \& perinatal risk factors}

These hypotheses propose that higher rates schizophrenia for people born in urban areas could arise from a set of biological influences confounded by urban birth, including exposure to infection in pregnancy and the perinatal period ${ }^{103}$ or obstetric complications. ${ }^{104-106}$ While these hypotheses are intuitively appealing, given that risk of infections, poorer prenatal nutrition or obstetric complications could more commonly occur in urban populations, evidence to support this is limited. Season of birth has been used as a proxy for infection during pregnancy (particularly with regard to influenza), but there is no evidence that this interacts with place of birth. ${ }^{22,26}$ Further studies which have directly tested whether exposure to prenatal infections confound the association between urban birth and schizophrenia are required. Only two studies, to our knowledge, has investigated whether obstetric complications confound or mediate the association between urban birth and schizophrenia, with no apparent relationship..$^{25,33}$ The overall paucity of studies investigating this potential risk pathway marks this as an important topic for future research.

\subsubsection{Social stressors}

The possibility that urban environments create stressful environments which in turn disrupts key neurobiological pathways relevant to psychosis has received considerable lip-service. ${ }^{107,108}$ Broadly, findings of higher rates of schizophrenia in neighbourhoods with greater levels of deprivation, population density and crime are consistent with the possibility that stress provides a mechanism to

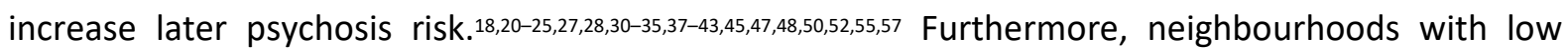
levels of protection from such risk factors, indexed by higher social fragmentation, lower levels of social cohesion ${ }^{61,63,64,66,67,73,74,97}$ or a lack of ethnic density, ${ }^{67,71}$ also appear to have increased rates. Nonetheless, studies which directly link exposure to urban environments with social stress, disrupted neurobiological process and psychosis are lacking, although new experimental data show that stressful social environments can increase paranoid ideation in healthy controls and people with existing psychosis. ${ }^{109}$ Furthermore, another experimental study (limited to healthy subjects) found that urban residence and upbringing were associated with increased amygdala activity and affected the perigenual anterior cingulate cortex - an area of the brain which regulates negative affect and stress. ${ }^{110}$ Specific hypotheses have also been advanced suggesting that experiences of social defeat or 
social exclusion could mediate the association between urban exposure and neurobiological processes at the basis of vulnerability to psychosis, ${ }^{111-113}$ though empirical evidence is still required. Alternatively, prolonged activation of the human stress response might suppress the Hypothalamicpituitary-adrenocortical axis, ${ }^{108}$ which, in turn, could result in dysfunctions of the immune system, predisposing some individuals to psychiatric illnesses.

\subsubsection{Gene-environment interactions}

An hypothesis that has increasingly gained attention is that environmental factors could combine with pre-existing genetic vulnerability to increase schizophrenia risk. ${ }^{114}$ This possibility is supported by findings of independent associations between older sibling and individual's urban birth and the risk of schizophrenia, suggesting that risk might reside both in familial and environmental factors. ${ }^{96}$ The lack of evidence to suggest that genetic risk differs between populations arranged along geographical or ethnic gradients, argues against a purely genetic explanation of higher rates of schizophrenia in urban populations and ethnic minorities, repsecitvely. ${ }^{115}$ Instead, underlying genetic vulnerabilities to psychosis may mean that subsequent exposure to stressful life events, psychosical adverisites and hostile social environments has a more deleterious effect on key neurobiological pathways that affect psychosis risk. Unfortunately, at present direct evidence for gene-environment interactions implicating the urban environment are largely absent. Results from large, multisite gene-environment interaction studies in schizophrenia may reveal new directions for research including whether increased polygenic risk for psychosis exacerbates later risk of psychosis following exposure to adverse social environments. ${ }^{116}$

\subsubsection{Differences in healthcare provision and socio-demographic characteristics}

Two further hypotheses have been suggested to explain observed differences. First, it has been suggested that differences in the provision of healthcare between areas could account for the observed spatial heterogeneity in the distribution of schizophrenia. While differential access to mental health care between urban and rural settings and possible variation in duration of untreated psychosis remain important issues in their own right, there is little evidence to suggest such issues will explain urban-rural differences in risk, ${ }^{117}$ given the use of population-based case ascertainment in studies which do not solely rely on routine case registers (i.e. see Kirkbride et al ${ }^{5,65,67,71}$ ).

Second, urban-rural differences in risk could be explained by differences in socio-demographic characteristics of individuals living in different areas (compositional effects). However, there is little evidence for this, although one study found that area-level differences disappeared after adjustment 


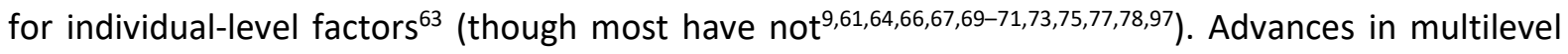
modelling techniques ${ }^{65,71}$ have helped to partition variation in incidence rates between individual- and neighbourhood-level factors. Most studies have investigated this variance in relation to the neighbourhood, but school environments may be highly relevant at certain ages, ${ }^{69}$ and the role of the family environment has largely been ignored, until very recently. ${ }^{76}$

\section{Common mental disorders (depression and anxiety)}

The annual prevalence of common mental disorders (CMD), defined as mood and anxiety disorders, has been recently estimated as $15.4 \%(95 \% \mathrm{Cl}: 12.8 \%-18.6 \%),{ }^{118}$ with higher rates in women compared with men for both mood (women: $7.3 \%, 95 \% \mathrm{Cl}: 6.5 \%-8.1 \%$; men: $4.0 \%, 95 \% \mathrm{Cl}: 3.5 \%-4.6 \%$ ) and anxiety (women: 8.7\%, 95\% Cl: 7.7\%-9.8\%; men: 4.3\%, 95\%Cl: 3.7\%-4.9\%). Compared with schizophrenia (Section 2), evidence for non-random spatial variation of CMD is more mixed. Although this may reflect real, context-specific differences, a number methodological limitations could also account for these more heterogeneous findings. As opposed to the literature on schizophrenia, for instance, fewer epidemiological studies of CMD have used longitudinal, population-based study designs (i.e. cohort studies), or have measured incidence ( $c f$. prevalence). Such studies are much harder to conduct for CMDs, given that a high proportion of people experiencing CMD may never present to mental health services. For this reason, cross-sectional surveys of the prevalence of CMDs in the general population or other settings have been more commonly used. Unfortunately, reliance on cross-sectional surveys and estimates of prevalence (which include both new and existing cases) makes it more difficult to separate cause from effect in respect to studying the role of the urban environment on risk of developing CMDs. Moreover, whilst ample literature exists, it has often been restricted to population sub-groups (e.g. adolescents, the elderly, ethnic minorities, or individuals with chronic disease), further limiting generalizability. Here, we review the strengths, weaknesses and overall level of evidence for spatial variation in CMDs.

\subsection{Urban vs. rural settings}

The majority of studies (Table 3 ) investigating the distribution of CMD between urban and rural settings have been conducted in Europe (three in the UK, ${ }^{119-121}$ three in The Netherlands, ${ }^{122-124}$ one in Sweden, ${ }^{35}$ one in France ${ }^{125}$ and one multi-country study across the UK, Spain, Finland, Ireland and Norway ${ }^{126}$ ). A number of studies have also been conducted in North America (four in Canada ${ }^{127-130}$ and six in the USA ${ }^{131-136}$ ), one across European and North American settings (Canada, USA, Turkey, 
Table 3: Summary of literature on rural/urban differences in the distribution of common mental disorders (from 1990 onwards, chronologically ordered)

\begin{tabular}{|c|c|c|c|c|c|c|c|c|}
\hline Study ID & Outcome & Instrument & $\begin{array}{l}\text { Sample size, } \\
\text { age }\end{array}$ & Definition of urban & $\begin{array}{c}\text { Timing of } \\
\text { urban }\end{array}$ & Findings & Confounders & Comments \\
\hline \multicolumn{9}{|c|}{ High Income Countries } \\
\hline $\begin{array}{l}\text { Lewis \& Booth }{ }^{119} \\
\text { (1994) } \\
\text { UK }\end{array}$ & Psychiatric morbidity & GHQ & $\begin{array}{c}\mathrm{N}=6,456, \\
\text { Age } 18 \text { or over }\end{array}$ & $\underline{\underline{\text { Urban (no open access), }}} \underline{\underline{\text { urban (open access), rural }}}$ & $\begin{array}{l}\text { At time of } \\
\text { survey }\end{array}$ & $\begin{array}{l}\text { Participants living in urban areas had higher } \\
\text { risk (odds) of experiencing psychiatric } \\
\text { morbidity cf. those in rural areas, with } \\
\text { access to open space associated with exact } \\
\text { risk }\end{array}$ & $\begin{array}{l}\text { Age, social class, marital } \\
\text { status, employment, } \\
\text { chronic illness \& region of } \\
\text { residence }\end{array}$ & $\begin{array}{l}\text { Partial dose-response } \\
\text { relationship observed. }\end{array}$ \\
\hline $\begin{array}{l}\text { Kessler et al }{ }^{131} \\
\text { (1994) } \\
\text { USA }\end{array}$ & $\begin{array}{c}\text { Any anxiety disorder/ } \\
\text { any mood disorder } \\
\text { DSM-III-R } \\
\text { (lifetime \& 12-month } \\
\text { prevalence) }\end{array}$ & CIDI & $\begin{array}{l}N=8.098 \\
\text { Age } 15-54\end{array}$ & $\underline{\text { Degree of urbanisation }}$ & $\begin{array}{l}\text { At time of } \\
\text { survey }\end{array}$ & $\begin{array}{l}\text { No difference in the distribution of anxiety } \\
\& \text { mood disorders between urban \& non- } \\
\text { urban areas }\end{array}$ & $\begin{array}{l}\text { Age, sex, ethnicity, } \\
\text { education, marital status, } \\
\text { region }\end{array}$ & \\
\hline $\begin{array}{l}\text { Blazer et al } \\
\text { (1994) } \\
\text { USA }^{132}\end{array}$ & $\begin{array}{c}\text { Major depression } \\
\text { DSM-III-R } \\
\text { (1-month prevalence) }\end{array}$ & CIDI & $\begin{array}{l}N=8.098 \\
\text { Age } 15-54\end{array}$ & $\underline{\text { Degree of urbanisation }}$ & $\begin{array}{l}\text { At time of } \\
\text { survey }\end{array}$ & $\begin{array}{c}\text { No difference in distribution of major } \\
\text { depression between urban \& non-urban } \\
\text { areas }\end{array}$ & $\begin{array}{l}\text { Age, sex, ethnicity, } \\
\text { education, marital status, } \\
\text { region, income, } \\
\text { employment, household } \\
\text { composition, religion } \\
\end{array}$ & \\
\hline $\begin{array}{l}\text { Parikh et al }{ }^{127} \\
\text { (1996) } \\
\text { Canada }\end{array}$ & $\begin{array}{l}\text { Affective disorders } \\
\text { DSM-III } \\
\text { [1-month prevalence] }\end{array}$ & UM-CIDI & $\begin{array}{c}N=9,953 \\
\text { Age } 15-64\end{array}$ & $\underline{\text { Urban vs. rural }}$ & $\begin{array}{l}\text { At time of } \\
\text { survey }\end{array}$ & $\begin{array}{c}\text { No differences between urban } \& \text { rural } \\
\text { areas }\end{array}$ & - & $\begin{array}{l}\text { No adjustment for } \\
\text { confounders }\end{array}$ \\
\hline $\begin{array}{l}\text { Paykel et al }{ }^{120} \\
\text { (2000) } \\
\text { UK }\end{array}$ & $\begin{array}{c}\text { Mood \& anxiety } \\
\text { disorders } \\
\text { DSM-III } \\
\text { [1-week prevalence] }\end{array}$ & CIS-R & $\begin{array}{c}N=9,748 \\
\text { Age } 16-64\end{array}$ & $\frac{\frac{\text { Self-reported rating of }}{\text { urban, semi-rural, rural }}}{\text { residence }}$ & $\begin{array}{l}\text { At time of } \\
\text { survey }\end{array}$ & $\begin{array}{l}\text { Higher risk (odds) of psychiatric morbidity } \\
\text { in urban } c f \text {. rural areas; no differences } \\
\text { between semi-rural \& rural. }\end{array}$ & $\begin{array}{l}\text { Age, sex, social class, } \\
\text { ethnicity, marital status, } \\
\text { education, employment, } \\
\text { housing type \& tenure, life } \\
\text { events in past year, social } \\
\text { network, social support }\end{array}$ & \\
\hline $\begin{array}{l}\text { Andrews et al }{ }^{137} \\
\text { (2001) } \\
\text { Australia }\end{array}$ & $\begin{array}{c}\text { Mood \& anxiety } \\
\text { disorders } \\
\text { ICD-10, DSM-IV } \\
\text { [12-month, 1-month } \\
\text { prevalence }\end{array}$ & MMSE & $\begin{array}{c}N=10,641 \\
\text { Age: } 16-64\end{array}$ & $\underline{\text { Urban vs. rural }}$ & $\begin{array}{l}\text { At time of } \\
\text { survey }\end{array}$ & $\begin{array}{l}\text { No differences in risk (odds) of mood \& } \\
\text { anxiety disorders between urban \& rural } \\
\text { areas in univariable models }\end{array}$ & & $\begin{array}{l}\text { No further testing in } \\
\text { multivariable models }\end{array}$ \\
\hline
\end{tabular}




\begin{tabular}{|c|c|c|c|c|c|c|c|c|}
\hline Study ID & Outcome & Instrument & $\begin{array}{c}\text { Sample size, } \\
\text { age }\end{array}$ & Definition of urban & $\begin{array}{c}\text { Timing of } \\
\text { urban }\end{array}$ & Findings & Confounders & Comments \\
\hline $\begin{array}{l}\text { Ayuso et al }{ }^{126} \\
\text { (2001) } \\
\text { Finland, Ireland, } \\
\text { Norway, UK, Spain }\end{array}$ & $\begin{array}{l}\text { Depressive disorder } \\
\qquad \text { ICD-10 } \\
\text { [1-month prevalence] }\end{array}$ & $\mathrm{BDI}+\mathrm{SCAN}$ & $\begin{array}{c}N=8,862 \\
\text { Age } 18-64\end{array}$ & $\underline{\text { Urban vs. rural }}$ & $\begin{array}{l}\text { At time of } \\
\text { survey }\end{array}$ & $\begin{array}{l}\text { Higher prevalence of mood disorders in } \\
\text { urban cf. rural areas. However, the } \\
\text { difference was only statistically significant } \\
\text { in UK \& Ireland }\end{array}$ & Age \& sex standardisation & $\begin{array}{l}\text { Low response rates in UK \& } \\
\text { Ireland may have biased } \\
\text { results. } \\
\text { Differences expressed as } \\
\text { means \& } 95 \% \mathrm{Cl} \text {, no adjusted } \\
\text { regression analyses }\end{array}$ \\
\hline $\begin{array}{l}\text { De Graaf et a }\left.\right|^{124} \\
\text { (2002) } \\
\text { The Netherlands }\end{array}$ & $\begin{array}{c}\begin{array}{c}\text { Mood \& anxiety } \\
\text { disorders }\end{array} \\
\text { DSMIII } \\
\text { incidence } \\
\end{array}$ & CIDI & $\begin{array}{c}\mathrm{N}=5,618 \\
\text { Age }=18-64\end{array}$ & $\underline{\text { Urban vs. rural }}$ & $\begin{array}{l}\text { At time of } \\
\text { survey }\end{array}$ & No difference between urban \& rural areas. & $\begin{array}{l}\text { Age, sex, education, } \\
\text { cohabitation status }\end{array}$ & \\
\hline $\begin{array}{l}\text { Andrade et a }{ }^{138} \\
\text { (2003) } \\
\text { Canada, Czech } \\
\text { Rep, Germany, } \\
\text { The Netherlands, } \\
\text { Turkey, USA }\end{array}$ & $\begin{array}{l}\text { Major depressive } \\
\text { episode } \\
\text { DSM-III-R in all } \\
\text { countries (exc. } \\
\text { Germany DSM-IV) } \\
\text { [lifetime prevalence] }\end{array}$ & CIDI & $\begin{array}{l}\text { Age varying } \\
\text { acorss studies, } \\
\text { overall from } 14 \\
\text { years or over }\end{array}$ & $\underline{\text { Urban vs. rural }}$ & $\begin{array}{l}\text { At time of } \\
\text { survey }\end{array}$ & $\begin{array}{l}\text { No difference between urban \& rural areas, } \\
\text { except in The Netherlands where risk } \\
\text { (odds) were lower in rural areas }\end{array}$ & $\begin{array}{c}\text { Other socio-demographc } \\
\text { variables investigated, but } \\
\text { not included in regression } \\
\text { models }\end{array}$ & $\begin{array}{l}\text { Response rate between } 56 \% \\
-88 \% \\
\text { No multivariable adjustment } \\
\text { for confounders }\end{array}$ \\
\hline $\begin{array}{l}\text { Kessler et al }{ }^{133} \\
\text { (2003) } \\
\text { USA }\end{array}$ & $\begin{array}{c}\text { Major depression } \\
\text { DSM-IV } \\
\text { [lifetime and } 12 \\
\text { month prevalence] }\end{array}$ & CIDI & $\begin{array}{c}\mathrm{N}=9,090 \\
\text { Age } 18 \text { or over }\end{array}$ & $\underline{\text { Degree of urbanisation }}$ & $\begin{array}{l}\text { At time of } \\
\text { survey }\end{array}$ & No difference between urban \& rural areas. & None & \\
\hline $\begin{array}{l}\text { Sundquist et a }{ }^{35} \\
\text { (2004) } \\
\text { Sweden }\end{array}$ & $\begin{array}{l}\text { Major Depression } \\
\text { ICD-9, ICD-10 \& DSM- } \\
\text { IV } \\
\text { Incidence }\end{array}$ & Registers & $\begin{array}{c}\text { Sample }=4.4 \mathrm{~m} \\
\text { Swedish people } \\
\text { aged } 25-64 \\
\text { years on } \\
31 / 12 / 1999 \\
(35,727 \text { people } \\
\text { excluded as they } \\
\text { had a previous } \\
\text { admission) } \\
\text { Cases }=7,751\end{array}$ & $\underline{\text { Degree of urbanisation }}$ & At diagnosis & $\begin{array}{l}\text { Risk of depression highest for men \& } \\
\text { women in most urbanised quintile, but } \\
\text { little evidence of dose-response }\end{array}$ & $\begin{array}{l}\text { Marital status, education, } \\
\text { immigrant status, age } \\
\text { (stratified by sex) }\end{array}$ & \\
\hline $\begin{array}{l}\text { Wang et al, (2004) } \\
\text { Canada }{ }^{130}\end{array}$ & $\begin{array}{c}\text { Major depressive } \\
\text { episode } \\
\text { DSM-III-R } \\
\\
\text { [12-month } \\
\text { prevalence] }\end{array}$ & CIDI & $\begin{array}{l}\mathrm{N}=17,244 \\
\text { Age } 12 \text { or over }\end{array}$ & $\underline{\text { Urban vs. rural }}$ & At diagnosis & $\begin{array}{l}\text { Higher risk (odds) of major depressive } \\
\text { episode in urban areas after multivariable } \\
\text { adjustment }\end{array}$ & $\begin{array}{l}\text { Employment, marital } \\
\text { status, ethnicity, } \\
\text { immigration status }\end{array}$ & \\
\hline
\end{tabular}




\begin{tabular}{|c|c|c|c|c|c|c|c|c|}
\hline Study ID & Outcome & Instrument & $\begin{array}{l}\text { Sample size, } \\
\text { age }\end{array}$ & Definition of urban & $\begin{array}{l}\text { Timing of } \\
\text { urban }\end{array}$ & Findings & Confounders & Comments \\
\hline $\begin{array}{l}\text { Kovess-Mafesty et } \\
\mathrm{al}^{125} \\
(2005) \\
\text { France }\end{array}$ & $\begin{array}{l}\text { Mood \& anxiety } \\
\text { disorders } \\
\text { DSM-IV } \\
\text { [lifetime, 6-month, 1- } \\
\text { year prevalence] }\end{array}$ & CIDI-SF & $\begin{array}{l}\mathrm{N}=2,638 \\
\begin{array}{l}\text { Age } 18-102 \\
\text { years }\end{array}\end{array}$ & $\underline{\text { Urban vs. rural }}$ & $\begin{array}{l}\text { At time of } \\
\text { survey }\end{array}$ & $\begin{array}{l}\text { No differences between urban \& rural } \\
\text { settings after multivariable adjustment }\end{array}$ & $\begin{array}{c}\text { Age, sex, education, } \\
\text { employment status, } \\
\text { marital status, country of } \\
\text { birth, housing tenure \& } \\
\text { type }\end{array}$ & \\
\hline $\begin{array}{l}\text { Patten et a } \mathrm{l}^{129} \\
\text { (2006) } \\
\text { Canada }\end{array}$ & $\begin{array}{l}\text { Major depressive } \\
\text { disorder/ episode } \\
\text { classification not } \\
\text { specified } \\
\text { [1-year / point } \\
\text { prevalence] }\end{array}$ & CIDI & $\begin{array}{l}\mathrm{N}=36,984 \\
\text { Age } 15 \text { or over }\end{array}$ & $\underline{\text { Unspecified }}$ & $\begin{array}{l}\text { At time of } \\
\text { survey }\end{array}$ & $\begin{array}{c}\text { No differences between urban \& rural } \\
\text { settings }\end{array}$ & $\begin{array}{l}\text { Age, sex, marital status, } \\
\text { income, education, } \\
\text { employment, chronic } \\
\text { conditions }\end{array}$ & \\
\hline $\begin{array}{l}\text { Probst et al }{ }^{134} \\
\text { (2006) } \\
\text { USA }\end{array}$ & $\begin{array}{l}\text { Depression } \\
\text { Classification not } \\
\text { specified } \\
\text { (unspecified } \\
\text { prevalence) }\end{array}$ & CIDI-SF & $\begin{array}{l}N=30,801 \\
\text { Age } 18-65\end{array}$ & $\underline{\text { Urban vs. rural }}$ & $\begin{array}{l}\text { At time of } \\
\text { survey }\end{array}$ & $\begin{array}{l}\text { Higher risk (odds) of depression in rural } \\
\text { populations, but no differences once other } \\
\text { health indicators were included }\end{array}$ & $\begin{array}{l}\text { Age, sex, ethnicity, self- } \\
\text { reported health, } \\
\text { education, income, marital } \\
\text { status, employment, } \\
\text { limitation in daily } \\
\text { activities, asthma, } \\
\text { hypertension, diabetes, } \\
\text { health status change }\end{array}$ & \\
\hline $\begin{array}{l}\text { Weich et al }{ }^{121} \\
\text { (2006) } \\
\text { UK }\end{array}$ & $\begin{array}{c}\text { Common mental } \\
\text { disorder (onset \& } \\
\text { maintenance) } \\
\text { [Point prevalence] }\end{array}$ & $\mathrm{GHQ}$ & $\begin{array}{l}\mathrm{N}=9518 \text { wave } 1 \\
\quad \text { (onset) } \\
\mathrm{N}=7659 \text { wave } 2 \\
\text { (maintenance) } \\
\text { Age }=17-64\end{array}$ & $\begin{array}{c}\text { Population density } \\
\qquad \underline{\&} \\
\text { Non-rural vs. rural }\end{array}$ & $\begin{array}{l}\text { At time of } \\
\text { survey }\end{array}$ & $\begin{array}{l}\text { Population density associated with } \\
\text { maintenance of CMD, but not onset. } \\
\text { Higher risk (odds) of CMD in non-rural } \\
\text { areas in univariable, but not multivariable } \\
\text { models }\end{array}$ & $\begin{array}{l}\text { Age, sex, marital status, } \\
\text { education, employment, } \\
\text { financial difficulties, } \\
\text { physical health, income, } \\
\text { housing tenure, type \& } \\
\text { problems, car access, } \\
\text { overcrowding, social class }\end{array}$ & $\begin{array}{l}\text { Non-rural areas do not } \\
\text { necessarily correspond to } \\
\text { urban areas } \\
\text { Study is based on prevalence } \\
\text { not incidence so 'onset' is a } \\
\text { partial misnoma }\end{array}$ \\
\hline $\begin{array}{l}\text { Grant et al }\left.\right|^{135} \\
\text { (2009) } \\
\text { USA }\end{array}$ & $\begin{array}{l}\text { Generalised anxiety } \\
\text { disorder (GAD) } \\
\text { DSM-IV } \\
\text { (Incidence \& } \\
\text { prevalence) }\end{array}$ & AUDADIS-IV & $N=34,653$ & $\underline{\text { Urban vs. rural }}$ & $\begin{array}{l}\text { At time of } \\
\text { survey }\end{array}$ & $\begin{array}{l}\text { No differences in risk (odds) of reporting } \\
\text { GAD between urban \& rural areas }\end{array}$ & $\begin{array}{l}\text { Age, sex, ethnicity, income } \\
\text { marital status, education, } \\
\text { region }\end{array}$ & $\begin{array}{l}\text { Only included GAD. Study } \\
\text { also investigated major } \\
\text { depressive disorder (MDD), } \\
\text { not included in this review; } \\
\text { no difference in urban-rural } \\
\text { distribution of MDD }\end{array}$ \\
\hline $\begin{array}{l}\text { Romans et a }\left.\right|^{128} \\
\text { (2011) } \\
\text { Canada }\end{array}$ & $\begin{array}{l}\text { Mood \& anxiety } \\
\text { Disorders } \\
\text { ICD-10, DSM-IV } \\
\text { [12-month } \\
\text { prevalence] }\end{array}$ & CIDI & $\begin{array}{c}N=31,321 \\
\text { Age } 15 \text { or over }\end{array}$ & $\underline{\text { Degree of urbanisation }}$ & $\begin{array}{l}\text { At time of } \\
\text { survey }\end{array}$ & $\begin{array}{c}\text { Weak evidence of difference in prevalence } \\
\text { across the } 4 \text { geographical areas, with } \\
\text { lower risk (odds) of depression in most } \\
\text { rural area }\end{array}$ & $\begin{array}{l}\text { Age, sex, marital status, } \\
\text { income, income adequacy, } \\
\text { employed, housing tenure, } \\
\text { country of origin, health, } \\
\text { ethnicity, education, } \\
\text { community support }\end{array}$ & $\begin{array}{l}\text { Anxiety as outcome was not } \\
\text { investigated in multivariable } \\
\text { models }\end{array}$ \\
\hline
\end{tabular}




\begin{tabular}{|c|c|c|c|c|c|c|c|c|}
\hline Study ID & Outcome & Instrument & $\begin{array}{l}\text { Sample size, } \\
\text { age }\end{array}$ & Definition of urban & $\begin{array}{l}\text { Timing of } \\
\text { urban }\end{array}$ & Findings & Confounders & Comments \\
\hline $\begin{array}{l}\text { De Graaf et al }{ }^{123} \\
\text { (2012) } \\
\text { The Netherlands }\end{array}$ & $\begin{array}{c}\text { Mood \& anxiety } \\
\text { Disorders } \\
\text { ICD-10, DSM-IV } \\
\text { [12-month } \\
\text { prevalence] }\end{array}$ & CIDI & $\begin{array}{c}N=6,646 \\
\text { Age: } 18-64\end{array}$ & 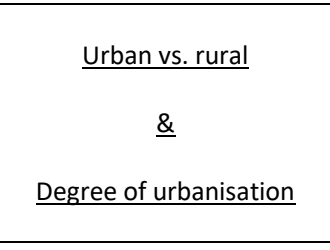 & $\begin{array}{l}\text { At time of } \\
\text { survey }\end{array}$ & $\begin{array}{c}\text { Lower risk (odds) of mood disorders in } \\
\text { more urbanised areas. Highest risk of } \\
\text { anxiety disorders in areas with very high } \\
\text { degrees of urbanisation cf. the most rural } \\
\text { areas. }\end{array}$ & Age \& sex & \\
\hline $\begin{array}{l}\text { De Graaf et a }\left.\right|^{122} \\
\text { (2013) } \\
\text { The Netherlands }\end{array}$ & $\begin{array}{l}\text { Mood \& anxiety } \\
\text { disorders } \\
\text { ICD-10, DSM-IV } \\
\text { [Incidence] } \\
\end{array}$ & CIDI & $\begin{array}{l}\mathrm{N}=5303 \text { (of the } \\
6,646 \text { eligible \& } \\
\text { invited) }\end{array}$ & Urban vs. rural & $\begin{array}{l}\text { At time of } \\
\text { survey }\end{array}$ & $\begin{array}{l}\text { No difference in incidence rate ratio of } \\
\text { mood \& anxiety disorders between urban \& } \\
\text { rural areas }\end{array}$ & Age \& sex & \\
\hline $\begin{array}{l}\text { Beyer et al }\left.\right|^{136} \\
\text { (2014) } \\
\text { USA }\end{array}$ & $\begin{array}{l}\text { Common Mental } \\
\text { Disorders } \\
\text { [Point prevalence] }\end{array}$ & DASS & $\begin{array}{c}\mathrm{N}=2,479 \\
\text { Age: } 21-74\end{array}$ & Degree of urbanisation & $\begin{array}{l}\text { At time of } \\
\text { survey }\end{array}$ & $\begin{array}{l}\text { Higher levels of depression \& anxiety } \\
\text { (though smaller coefficient \& weaker } \\
\text { association in the latter) in less urbanised } \\
\text { areas but with no evidence of a linear } \\
\text { relationship. Population density not } \\
\text { associated with CMD }\end{array}$ & $\begin{array}{l}\text { Age, sex, ethnicity, marital } \\
\text { status, education, } \\
\text { household income, } \\
\text { occupational status, } \\
\text { health insurance; green } \\
\text { spaces, \% tree canopy, } \\
\text { urbanicity, population } \\
\text { density, median } \\
\text { household income below } \\
\text { poverty, residential } \\
\text { instability, \% owner } \\
\text { occupied households \& } \\
\text { unemployed, ethnic } \\
\text { segregation } \\
\end{array}$ & \\
\hline \multicolumn{9}{|l|}{ LAMIC } \\
\hline $\begin{array}{l}\text { Mohammadi et } \\
\text { a }^{139} \\
(2005) \\
\text { Iran }\end{array}$ & $\begin{array}{l}\text { Mood \& anxiety } \\
\text { disorders } \\
\text { (DSM-IV) } \\
\text { [Lifetime prevalence] }\end{array}$ & SADS & $\begin{array}{l}N=25,180 \\
\text { Age } 18 \text { or over }\end{array}$ & $\underline{\text { Urban vs. rural }}$ & $\begin{array}{l}\text { At time of } \\
\text { survey }\end{array}$ & $\begin{array}{l}\text { Higher risk (odds) of mood \& anxiety } \\
\text { disorders in urban cf. rural area }\end{array}$ & Unspecified & $\begin{array}{l}\text { Unclear if odds ratios were } \\
\text { from univariable or } \\
\text { multivariable analyses }\end{array}$ \\
\hline $\begin{array}{l}\text { Vicente et al50 } \\
\text { (2006) } \\
\text { Chile }\end{array}$ & $\begin{array}{l}\text { Mood \& anxiety } \\
\text { disorders } \\
\text { DSM-III-R } \\
\text { [Lifetime, 12-month } \\
\text { prevalence] }\end{array}$ & (CIDI) & $\begin{array}{c}\mathrm{N}=2,978 \\
\text { Age: } 15 \text { or over }\end{array}$ & $\begin{array}{l}\text { Analyses grouped by } 4 \\
\text { geographical regions, with } \\
\text { different } \% \text { of rural } \\
\text { population }\end{array}$ & $\begin{array}{l}\text { At time of } \\
\text { survey }\end{array}$ & $\begin{array}{l}\text { No differences across } 4 \text { regions in } \\
\text { prevalence of disorders }\end{array}$ & $\begin{array}{l}\text { Age, sex, education, } \\
\text { marital status, income }\end{array}$ & $\begin{array}{l}\text { Urban-rural areas not } \\
\text { directly compared. }\end{array}$ \\
\hline
\end{tabular}




\begin{tabular}{|c|c|c|c|c|c|c|c|c|}
\hline Study ID & Outcome & Instrument & $\begin{array}{l}\text { Sample size, } \\
\text { age }\end{array}$ & Definition of urban & $\begin{array}{l}\text { Timing of } \\
\text { urban }\end{array}$ & Findings & Confounders & Comments \\
\hline $\begin{array}{l}\text { Amoran et a } 1^{140} \\
(2007) \\
\text { Nigeria }\end{array}$ & $\begin{array}{l}\text { Common mental } \\
\text { disorders } \\
\text { [Point prevalence] }\end{array}$ & $\mathrm{GHQ}$ & $\begin{array}{l}\mathrm{N}=1,105 \\
\text { Age } 15 \text { or over }\end{array}$ & Urban vs. rural & $\begin{array}{l}\text { At time of } \\
\text { survey }\end{array}$ & $\begin{array}{c}\text { Higher prevalence of depression in rural } \\
\text { areas }\end{array}$ & - & $\begin{array}{l}\text { No control for confounders, } \\
\text { statistical tests only } \\
\text { conducted for depression, } \\
\text { not anxiety }\end{array}$ \\
\hline $\begin{array}{l}\text { Wei et a a }{ }^{51} \\
(2008) \\
\text { Tibet }\end{array}$ & $\begin{array}{c}\text { Depression } \\
\text { DSM-IV } \\
\text { Point prevalence } \\
\end{array}$ & SCID-I & $\begin{array}{c}\text { Sample }=5,145 \\
\text { Cases }=\text { N/A }\end{array}$ & City vs rural areas & At diagnosis & $\begin{array}{l}\text { No significant differences between urban \& } \\
\text { rural areas }\end{array}$ & - & No multivariable analysis \\
\hline $\begin{array}{l}\text { Lundberg et al } \\
\text { (2009) } \\
\text { Uganda }\end{array}$ & $\begin{array}{l}\text { Depression \& anxiety } \\
\text { (classification not } \\
\text { specified) } \\
\text { [point prevalence] }\end{array}$ & $\mathrm{HSCL}-25$ & Sample $=646$ & $\begin{array}{c}\text { Number of inhabitants } \\
\text { Urban }=\text { Kampala } \\
\text { Semi-urban }=>25,000 \\
\text { inhabitants } \\
\text { Rural } \leq 25,000 \text { inhabitants }\end{array}$ & $\begin{array}{l}\text { Birth \& } \\
\text { upbringing }\end{array}$ & $\begin{array}{l}\text { People born in urban areas had higher risk } \\
\text { (odds) of having depression \& anxiety }\end{array}$ & $\begin{array}{l}\text { Age, gender, education, } \\
\text { marital status, SES, family } \\
\text { history of psychiatric } \\
\text { disorders }\end{array}$ & $\begin{array}{l}\text { Small sample, type II error } \\
\text { cannot be ruled out. }\end{array}$ \\
\hline
\end{tabular}

List of abbreviations: AUDADIS-IV= Alcohol Use Disorder and Associated Disabilities Interview Schedule DSM-IV Version; BDI= Beck Depression Inventory ; CIDI:= Composite International Diagnostic Interview; CIDI-SF= Composite International Diagnostic Interview short form; CIS-R= Clinical Interview Schedule Revised; DASS = Depression Anxiety Stress Scale ; GHQ= General Health Questionnaire; DSM = Diagnostic and Statistical Manual of mental disorders; HSCL = Hopkins Symptoms Checklist; ICD = International Classification of Disease; MMSE= Mini Mental State Examination; SADS= Somatic Anxiety Depressive Symptoms scale; SCAN= Schedules for Clinical Assessment in Neuropsychiatry; $c f .=$ compared with 
Germany, The Netherlands, and Czech Republic), ${ }^{138}$ one in South America (Chile ${ }^{50}$ ), one in Australia, ${ }^{137}$ two in Africa (Nigeria ${ }^{140}$ and Uganda ${ }^{52}$ ), and two in central Asia (Iran ${ }^{139}$ and Tibet $\left.{ }^{51}\right)$.

All studies employed a cross-sectional design, with the exception of one longitudinal cohort ${ }^{35}$ and two incidence-based studies. ${ }^{122,124}$ Studies investigated CMD across a variety of ages, beginning in mid- to late-adolescence. Even though all investigations recorded place of residence concomitantly to the time of the survey, definitions of urbanicity varied considerably; while the majority of studies defined urbanicity according to degree of urbanisation ${ }^{52,122,123,125,127,128,131-133,136,137,141}$ or population density, ${ }^{35,121,124,130,135}$ others were based on combined metrics (population density and employment in rural occupations such as fishing, agriculture, etc), ${ }^{126}$ housing type ${ }^{119,125}$, self-report ${ }^{120}$ or the percentage of survey respondents classified as from a rural district. ${ }^{50}$ Six studies provided no criteria to define urbanicity. ${ }^{51,129,135,138-140}$ All studies, with the exception of one (at birth), ${ }^{52}$ measured urbanicity at time of diagnosis.

Most studies investigated urban-rural variation of mood and anxiety disorders together, ${ }^{119-}$ $125,128,131,136,139,140,142$ with eight studies restricted to mood (depressive) disorders only, ${ }^{126,127,129,130,132-}$ 134,138 and one restricted to anxiety disorders. ${ }^{135} \mathrm{~A}$ handful of other studies considered depression and anxiety alongside other psychiatric conditions. ${ }^{35,50-52}$ Diagnostic criteria, however, varied greatly across studies; eight studies used DSM-III or DSM-III-R criteria, ${ }^{50,120,124,127,130-132,138}$ four used DSMIV, ${ }^{51,125,133,135,139}$ one used ICD-10, ${ }^{126}$ five used a combination of ICD-10 and DSM-IV ${ }^{35,122,123,128,137}$ and the remainder reported general psychopathology scores without reference to specific diagnostic classifications. ${ }^{119,121,129,134,136,140}$ A range of different instruments (CIDI, ${ }^{50,122-125,127-133,138,141}$ DASS, ${ }^{136}$ AUDADIS-IV, ${ }^{135}$ GHQ, ${ }^{119,121,140}$ SCID-I, ${ }^{51}$ CIS-R, ${ }^{120}$ BDI, ${ }^{126}$ MMSE, ${ }^{137}$ HSCL-25 ${ }^{52}$ and SADS ${ }^{139}$ ) were employed to diagnose incidence, ${ }^{124,135}$ and point, ${ }^{51,52,129,136,140}$ week, $^{120}$ month, $^{126,127,132,142}$ annual, $^{50,125,128,129,131,133,142}$ three-year ${ }^{122}$ and lifetime CMD prevalence. ${ }^{50,125,131,133,139}$ One study employed register data to measure incidence of depression. ${ }^{35}$

Perhaps unsurprisingly, results from these diverse study designs were highly heterogeneous. Eight studies found higher prevalence or risk (expressed as odds ratios) of CMD in urban areas, $^{35,52,119,120,126,128,130,139}$ two in rural settings, ${ }^{136,140}$ while fourteen observed no differences. ${ }^{50,51,121,122,124,125,127,129,131-133,135,141,142}$ One study reported a higher risk of depression in rural areas, but the opposite for anxiety disorders, ${ }^{123}$ whereas another study found no rural-urban differences in five out of six countries (Canada, USA, Turkey, Germany, and Czech Republic). ${ }^{138}$ Moreover, studies which used a categorical (i.e. non-binary) indicators of urbanisation, found little or 
no evidence supporting the presence of a dose-response relationship between the degree of urbanisation and prevalence or risk of CMD..$^{35,120,122,127,128,131-133,136,142}$

\subsection{Neighbourhoods}

A large literature has also investigated whether CMDs vary between small area neighbourhoods (Table 4), beyond variation which might exist between rural and urban populations (Section 3.1). Given the breadth of the available research, we have restricted our primary focus on general adult population studies, consistent with other sections of this chapter. As before, most studies have been conducted in Western Europe (twelve in UK, ${ }^{143-154}$ two in The Netherlands, ${ }^{155,156}$ two in Sweden, ${ }^{64,157}$ one in France ${ }^{158}$ and one across several cities ${ }^{159}$ ) and North America (twelve in the United States, ${ }^{136,160-169}$ three in Canada ${ }^{170-172}$ ), with others undertaken in Australia, ${ }^{173}$ Brazil $^{174}$ and South Africa. ${ }^{175}$

As for the urban-rural literature, the evidence for neighbourhood variation in CMD risk is more mixed than for schizophrenia. Whilst up to $12 \%$ of variance in schizophrenia might have been explained at the area-level, for CMD this proportion was much smaller, ranging from none to $4.4 \%{ }^{64,145-}$ 147,153,154,156,158,172,176 Moreover, whilst many studies reported significant associations between CMD and at least one neighbourhood factor, , $^{136,143,144,148,150,152-154,156,158-160,165,170,171,173-175,177-179}$ a considerable number found no associations. ${ }^{144-147,149,151,155,160,161,163,167}$ Interestingly, whilst many studies did not find an overall main effect of neighbourhood factors on CMD risk, many studies reported subgroup effects, ${ }^{145,148,150,154,159,160}$ which suggested that the role of neighbourhood factors such as deprivation were associated with CMD risk in particularly disadvantaged individuals. While more research is needed, this suggests that social adversities at the neighbourhood level many be particularly detrimental to the mental health of people who already face individual level social disadvantage. Deprivation was most commonly investigated, ${ }^{64,136,145,147-149,151-154,156-}$ $158,162,163,167,168,170,172,173,177$ followed by ethnic density, ${ }^{150,160,170,178}$ social capital, , $4,149,156,165,179$ and features of the built environment (virtually absent in the schizophrenia literature), such as housing, ${ }^{143,144}$ neighbourhood quality ${ }^{143,159}$ or green space. ${ }^{136,143,171}$

With the exception of three observational studies employing longitudinal designs to examine either: maintenance of $\mathrm{CMD}$ symptoms ${ }^{147,168}$; social drift in individuals with $\mathrm{CMD},{ }^{173}$ or; the association between the built environment and trajectories of depressive symptoms, ${ }^{171}$ as well a randomised controlled trial, ${ }^{164}$ all neighbourhood-level studies of CMD have employed cross-sectional designs. Place of residence has been exclusively measured at the time of data collection, although one longitudinal study was based on residence at multiple time-points. ${ }^{173}$ 
Table 4: Summary of literature on neighbourhood differences in the distribution of CMD (from 1990 onwards, chronologically ordered) 


\begin{tabular}{|c|c|c|c|c|c|c|c|c|c|}
\hline $\begin{array}{l}\text { Study ID \& } \\
\text { Setting }\end{array}$ & $\begin{array}{l}\text { Outcome \& } \\
\text { Instrument }\end{array}$ & $\begin{array}{l}\text { Case finding, } \\
\text { age range, } \\
\text { years }\end{array}$ & Sample size & $\begin{array}{c}\text { Definition of } \\
\text { neighbourhood }\end{array}$ & $\begin{array}{l}\text { Timing of } \\
\text { exposure }\end{array}$ & $\begin{array}{l}\text { Area-levels } \\
\text { measures }\end{array}$ & $\begin{array}{l}\text { Individual-level } \\
\text { measures }\end{array}$ & Findings & Comments \\
\hline $\begin{array}{l}\text { Tweed }^{160} \\
(1990) \\
\text { USA }\end{array}$ & $\begin{array}{l}\text { Depressed } \\
\text { mood } \\
\text { (DIS) } \\
\text { [6-month } \\
\text { prevalence] }\end{array}$ & $\begin{array}{l}\text { Survey } \\
\text { Age 18+ }\end{array}$ & $N=3,481$ & $\begin{array}{l}\text { Neighbourhoods in } \\
\text { Baltimore }\end{array}$ & $\begin{array}{l}\text { At time of } \\
\text { Survey }\end{array}$ & Ethnic congruence & Age, sex, SES, ethnicity & $\begin{array}{l}\text { Six-month prevalence was lower in } \\
\text { neighbourhoods with highest ethnic } \\
\text { congruence. Effect was greater for } \\
\text { participants of black ethnicity }\end{array}$ & \\
\hline $\begin{array}{l}\text { Reijneveld \& } \\
\text { Schene }^{155} \\
\text { (1998) } \\
\text { The Netherlands }\end{array}$ & $\begin{array}{l}\text { Common } \\
\text { Mental } \\
\text { Disorders } \\
\\
\text { GHQ-12 } \\
\text { [point } \\
\text { prevalence] }\end{array}$ & $\begin{array}{l}\text { Survey, } \\
\text { Age: } 16+\end{array}$ & $\mathrm{N}=4,892$ & $\begin{array}{l}\text { Boroughs in } \\
\text { Amsterdam }\end{array}$ & $\begin{array}{l}\text { At time of } \\
\text { Survey }\end{array}$ & $\begin{array}{l}\text { Area-level deprivation: } \\
\text { registered income, } \\
\text { household } \\
\text { income below minimum, } \\
\text { and unemployment rate }\end{array}$ & $\begin{array}{l}\text { Age, sex, income, } \\
\text { occupational status \& } \\
\text { educational level }\end{array}$ & $\begin{array}{c}\text { Higher risk (odds) in more deprived } \\
\text { neighbourhoods, but disappeared } \\
\text { after adjustment }\end{array}$ & $\begin{array}{l}\text { Similar results } \\
\text { obtained when } \\
\text { restricted to } \\
\text { Dutch-born } \\
\text { participants. }\end{array}$ \\
\hline $\begin{array}{l}\text { Yen \& Kaplan }{ }^{161} \\
\text { (1999) } \\
\text { USA }\end{array}$ & $\begin{array}{c}\text { Depressive } \\
\text { symptoms } \\
\text { 18-item } \\
\text { depressive } \\
\text { symptom scale }\end{array}$ & $\begin{array}{l}\text { Survey } \\
\text { Age: } 20+ \\
\text { Years: } 1965- \\
1970\end{array}$ & $N=1,296$ & Census tracts & $\begin{array}{l}\text { At time of } \\
\text { survey }\end{array}$ & $\begin{array}{l}\text { Neighbourhood SES: (\% } \\
\text { population with low } \\
\text { income; living in } \\
\text { substandard housing, low } \\
\text { education, unskilled male } \\
\text { labours, children in single } \\
\text { parent homes) }\end{array}$ & $\begin{array}{l}\text { Age, sex, ethnicity, } \\
\text { income, chronic } \\
\text { conditions, smoking, } \\
\text { alcohol \& BMI }\end{array}$ & $\begin{array}{l}\text { No differences in depressive } \\
\text { symptoms between low \& high SES } \\
\text { neighbourhoods }\end{array}$ & \\
\hline $\begin{array}{l}\text { Ross et al } 162 \\
\text { (2000) } \\
\text { USA }\end{array}$ & $\begin{array}{l}\text { Depression \& } \\
\text { anxiety } \\
\text { (modified CES- } \\
\text { D) }\end{array}$ & $\begin{array}{c}\text { Survey } \\
\text { Age: } 18-92 \\
\text { Years: } 1995\end{array}$ & $\mathrm{~N}=2,482$ & $\begin{array}{l}\text { US census/postcode } \\
\text { tracts }\end{array}$ & $\begin{array}{l}\text { At time of } \\
\text { survey }\end{array}$ & $\begin{array}{l}\text { Neighbourhood SES; } \\
\text { perceived neighbourhood } \\
\text { disorder (physical \& } \\
\text { social) }\end{array}$ & $\begin{array}{l}\text { Age gender, ethnicity, } \\
\text { income education, } \\
\text { marital, and parental } \\
\text { status, employment and } \\
\text { urban residence }\end{array}$ & $\begin{array}{l}\text { Neighbourhood disorder associated } \\
\text { with more symptoms of depression \& } \\
\text { anxiety in adjusted models, but not } \\
\text { neighbourhood SES }\end{array}$ & \\
\hline $\begin{array}{l}\text { McCulloch }{ }^{151} \\
\text { (2001) } \\
\text { UK }\end{array}$ & $\begin{array}{l}\text { Common } \\
\text { Mental } \\
\text { Disorders } \\
\\
\text { GHQ-12 } \\
\text { [point } \\
\text { prevalence] }\end{array}$ & $\begin{array}{l}\text { Survey } \\
\text { Age: } 16-75 \\
\text { (year 1991- } \\
\text { 1998) }\end{array}$ & $N=10,264$ & N/A & $\begin{array}{l}\text { At time of } \\
\text { survey }\end{array}$ & $\begin{array}{l}\text { Area-level deprivation } \\
\text { (Townsend index) }\end{array}$ & $\begin{array}{l}\text { Region of residence, } \\
\text { year, education, } \\
\text { ethnicity, housing } \\
\text { tenure, access to car, } \\
\text { employment }\end{array}$ & $\begin{array}{l}\text { No association between deprivation } \\
\text { and CMD after adjustment for other } \\
\text { confounders }\end{array}$ & $\begin{array}{l}\text { Household-level } \\
\text { characteristics } \\
\text { not included in } \\
\text { multilevel } \\
\text { model }\end{array}$ \\
\hline
\end{tabular}




\begin{tabular}{|c|c|c|c|c|c|c|c|c|c|}
\hline $\begin{array}{l}\text { Study ID \& } \\
\text { Setting }\end{array}$ & $\begin{array}{l}\text { Outcome \& } \\
\text { Instrument }\end{array}$ & $\begin{array}{l}\text { Case finding, } \\
\text { age range, } \\
\text { years }\end{array}$ & Sample size & $\begin{array}{c}\text { Definition of } \\
\text { neighbourhood }\end{array}$ & $\begin{array}{l}\text { Timing of } \\
\text { exposure }\end{array}$ & $\begin{array}{c}\text { Area-levels } \\
\text { measures }\end{array}$ & $\begin{array}{l}\text { Individual-level } \\
\text { measures }\end{array}$ & Findings & Comments \\
\hline $\begin{array}{l}\text { Weich et al }{ }^{144} \\
\text { (2002) } \\
\text { UK }\end{array}$ & $\begin{array}{l}\text { Depressive } \\
\text { symptoms } \\
\text { CES-D } \\
\text { [prevalence] }\end{array}$ & $\begin{array}{c}\text { Survey } \\
\text { Age: } 16-75\end{array}$ & $N=1,887$ & $\begin{array}{c}86 \text { housing areas } \\
\text { (geographically } \\
\text { bounded areas in } \\
\text { which the majority } \\
\text { of the housing was } \\
\text { homogeneous in } \\
\text { form and character) } \\
2 \text { Wards in North } \\
\text { London }\end{array}$ & $\begin{array}{l}\text { At time of } \\
\text { survey }\end{array}$ & $\begin{array}{l}\text { Built environment side } \\
\text { survey checklist (BESSC) }\end{array}$ & $\begin{array}{l}\text { Age, sex, marital status, } \\
\text { employment, ethnicity, } \\
\text { education. Household: } \\
\text { tenure, level, structural } \\
\text { problems }\end{array}$ & $\begin{array}{c}\text { After adjusting for other } \\
\text { characteristics, only living in areas } \\
\text { with majority of buildings built after } \\
\text { 1970s (vs pre-1940s) \& with less than } \\
25 \% \text { of dwellings with private garden } \\
\text { was associated with higher risk (odds) } \\
\text { of depressive symptoms }\end{array}$ & \\
\hline $\begin{array}{l}\text { Stafford \& } \\
\text { Marmot }{ }^{148} \\
(2003) \\
\text { UK }\end{array}$ & $\begin{array}{l}\text { Depression } \\
\text { GHQ-28 } \\
\text { [point } \\
\text { prevalence] }\end{array}$ & $\begin{array}{l}\text { Cohort study } \\
\text { (wave 5) }\end{array}$ & $N=5,539$ & Electoral wards & $\begin{array}{l}\text { At time of } \\
\text { survey }\end{array}$ & $\begin{array}{l}\text { Neighbourhood } \\
\text { deprivation (Townsend } \\
\text { score, } 1991 \text { census); self- } \\
\text { reported measure of } \\
\text { neighbourhood safety }\end{array}$ & $\begin{array}{l}\text { Age, sex, SES, financial } \\
\text { problems, satisfaction } \\
\text { with standard of living }\end{array}$ & $\begin{array}{l}\text { Deprivation was associated with } \\
\text { higher risk (odds) of depression. } \\
\text { Some weak evidence that this was } \\
\text { worse for people of low SES in such } \\
\text { deprived areas }\end{array}$ & \\
\hline $\begin{array}{l}\text { Weich et al }{ }^{145} \\
\text { (2003) } \\
\text { UK }\end{array}$ & $\begin{array}{l}\text { Common } \\
\text { Mental } \\
\text { Disorders } \\
\text { GHQ-12 } \\
\text { [point } \\
\text { prevalence] }\end{array}$ & $\begin{array}{c}\text { Survey } \\
\text { Age: } 16-74\end{array}$ & $N=8,979$ & Electoral wards & $\begin{array}{l}\text { At time of } \\
\text { survey }\end{array}$ & $\begin{array}{l}\text { Area-level deprivation } \\
\text { (Cartairs index of } \\
\text { socioeconomic } \\
\text { deprivation), population } \\
\text { density }\end{array}$ & $\begin{array}{l}\text { Age, sex, marital status, } \\
\text { ethnicity, employment } \\
\text { status, number of } \\
\text { current physical health } \\
\text { problems. Household } \\
\text { level: head of the } \\
\text { household SES, } \\
\text { structural housing } \\
\text { problems, low income, } \\
\text { access to a car \& } \\
\text { overcrowding } \\
\end{array}$ & $\begin{array}{l}\text { Negligible variance in CMD explained } \\
\text { at area level, with no main effect for } \\
\text { deprivation after adjusting for other } \\
\text { characteristics. Possible subgroup } \\
\text { effect of deprivation on CMD risk in } \\
\text { the unemployed \& economically } \\
\text { inactive. }\end{array}$ & \\
\hline $\begin{array}{l}\text { Weich et a } 1^{146} \\
\text { (2003) } \\
\text { UK }\end{array}$ & $\begin{array}{l}\text { Common } \\
\text { Mental } \\
\text { Disorders } \\
\text { GHQ-12 } \\
\text { [point } \\
\text { prevalence] }\end{array}$ & $\begin{array}{l}\text { Survey e British } \\
\text { Household } \\
\text { Panel Survey } \\
\text { (BHPS) }\end{array}$ & $N=8,979$ & $\begin{array}{l}\text { Electoral wards } \\
(\sim 2,400 \text { adresses })\end{array}$ & $\begin{array}{l}\text { At time of } \\
\text { survey }\end{array}$ & $\begin{array}{l}\text { None (neighbourhood } \\
\text { employed as unit in } \\
\text { multilevel modelling) }\end{array}$ & $\begin{array}{l}\text { Age, sex, marital status, } \\
\text { ethnicity, education, } \\
\text { employment status, } \\
\text { financial strain \& current } \\
\text { physical health problems } \\
\text { Household level: } \\
\text { structural housing } \\
\text { problems, household } \\
\text { income, access to a car, } \\
\text { tenure, SES, } \\
\text { overcrowding, } \\
\text { household type }\end{array}$ & $\begin{array}{c}\text { CMD as binary outcome: } \\
\text { No significant area-level variance. In } \\
\text { adjusted models } 94 \% \text { of variance was } \\
\text { explained at the individual level, } 6 \% \\
\text { at area level } \\
\text { GHQ score (continuous): } \\
0.9 \% \text { of variance at area level } \\
\text { (significant) no longer significant in } \\
\text { adjusted models, where } 89 \% \text { of } \\
\text { variance was explained at individual } \\
\text { level, } 10 \% \text { at household level }\end{array}$ & \\
\hline
\end{tabular}




\begin{tabular}{|c|c|c|c|c|c|c|c|c|c|}
\hline $\begin{array}{l}\text { Study ID \& } \\
\text { Setting }\end{array}$ & $\begin{array}{l}\text { Outcome \& } \\
\text { Instrument }\end{array}$ & $\begin{array}{l}\text { Case finding, } \\
\text { age range, } \\
\text { years }\end{array}$ & Sample size & $\begin{array}{c}\text { Definition of } \\
\text { neighbourhood }\end{array}$ & $\begin{array}{l}\text { Timing of } \\
\text { exposure }\end{array}$ & $\begin{array}{l}\text { Area-levels } \\
\text { measures }\end{array}$ & $\begin{array}{l}\text { Individual-level } \\
\text { measures }\end{array}$ & Findings & Comments \\
\hline $\begin{array}{l}\text { Leventhal \& } \\
\text { Brooks Gunn } \\
\text { (2004) } \\
\text { USA }\end{array}$ & $\begin{array}{c}\text { Depressive } \\
\text { symptoms } \\
\text { DMI } \\
\text { Depressive } \\
\text { mood inventory }\end{array}$ & $\begin{array}{c}\text { RCT } \\
\text { [treatment arm: } \\
\text { moved to low } \\
\text { poverty } \\
\text { neighbourhood } \\
\text { s + received } \\
\text { voucher; } \\
\text { comparison } \\
\text { arm: voucher } \\
\text { only; control } \\
\text { arm: did not } \\
\text { change } \\
\text { residence] } \\
\end{array}$ & $N=550$ & Not defined & $\begin{array}{l}\text { As assigned } \\
\text { by RCT }\end{array}$ & $\begin{array}{l}\text { Neighbourhood physical } \\
\& \text { social disorder } \\
\text { measured by parental } \\
\text { ratings of the size of } \\
\text { problems. (parent \& } \\
\text { interviewer rated) }\end{array}$ & $\begin{array}{l}\text { Neighbourhood } \\
\text { satisfaction. } \\
\text { Family randomised } \\
\text { based on age, ethnicity, } \\
\text { sex, education, marital } \\
\text { status, employment }\end{array}$ & $\begin{array}{l}\text { Parents in treatment arm were less } \\
\text { likely to report depressive mood }\end{array}$ & $\begin{array}{l}69 \% \text { response } \\
\text { rate at follow } \\
\text { up }\end{array}$ \\
\hline $\begin{array}{l}\text { Wainwright et } \\
\text { al }^{152} \\
(2004) \\
\text { UK }\end{array}$ & $\begin{array}{l}\text { Mood disorder } \\
\text { Health and Life } \\
\text { Experiences } \\
\text { Questionnaire } \\
\text { (HLEQ) } \\
\text { [current \& } \\
\text { lifetime } \\
\text { prevalence] }\end{array}$ & $\begin{array}{l}\text { Survey } \\
\text { Age: } 41-80 \\
\text { years }\end{array}$ & $N=19,687$ & Electoral ward & $\begin{array}{l}\text { At time of } \\
\text { survey }\end{array}$ & $\begin{array}{l}\text { Index of Multiple } \\
\text { Deprivation }\end{array}$ & $\begin{array}{l}\text { Age, sex, social class, } \\
\text { marital status, } \\
\text { employment status \& } \\
\text { educational level }\end{array}$ & $\begin{array}{l}\text { Higher risk (odds) of reporting mood } \\
\text { disorder for participants living in } \\
\text { more deprived areas after accounting } \\
\text { for individual-level characteristics. } \\
\text { Non-significant } 0.4 \% \text { variation at area } \\
\text { level once all individual level variables } \\
\text { were included }\end{array}$ & \\
\hline $\begin{array}{l}\text { Greiner et a } 1^{165} \\
\text { (2004) } \\
\text { USA }\end{array}$ & $\begin{array}{l}\text { Depressive } \\
\text { symptoms } \\
\text { One } \\
\text { (unspecified) } \\
\text { option question } \\
\text { [prevalence] }\end{array}$ & $\begin{array}{c}\text { Survey } \\
\text { Age } 18 \text { or over }\end{array}$ & $\mathrm{N}=4,601$ & $\begin{array}{l}\text { Community as } \\
\text { perceived by } \\
\text { respondent }\end{array}$ & $\begin{array}{l}\text { At time of } \\
\text { survey }\end{array}$ & $\begin{array}{l}\text { Community rating, } \\
\text { community involvement, } \\
\text { population density }\end{array}$ & $\begin{array}{l}\text { Age, sex, race, education } \\
\& \text { identification of a } \\
\text { personal health-care } \\
\text { provider }\end{array}$ & $\begin{array}{l}\text { Higher community ratings were } \\
\text { associated with lower risk (odds) of } \\
\text { reporting depressive symptoms }\end{array}$ & $\begin{array}{l}\text { Self-rated } \\
\text { measures of } \\
\text { area could be } \\
\text { affected by } \\
\text { depressive } \\
\text { symptom levels }\end{array}$ \\
\hline $\begin{array}{l}\text { Propper et a } 1^{176} \\
\text { (2005) } \\
\text { UK }\end{array}$ & $\begin{array}{l}\text { Common } \\
\text { Mental } \\
\text { Disorders } \\
\text { GHQ-12 } \\
\text { [point } \\
\text { prevalence] }\end{array}$ & $\begin{array}{l}\text { Survey (1991- } \\
\text { 2000) }\end{array}$ & $\begin{array}{c}\mathrm{N}=8184 \text { (for } \\
\text { prevalence) } \\
\\
\mathrm{N}=7047 \text { ( } 5 \\
\text { year analyses) }\end{array}$ & $\begin{array}{l}\text { Enumeration district } \\
\text { ( 500 people) }\end{array}$ & $\begin{array}{l}\text { At time of } \\
\text { survey }\end{array}$ & $\begin{array}{l}\text { \% unemployed, long term } \\
\text { sick age } 16-64, \text { tenure } \\
\text { type, central heating, no } \\
\text { car, crowding, lone } \\
\text { parent, one person } \\
\text { (pensioner/non } \\
\text { pensioner), black, Indian, } \\
\text { Pakistani, Bangladeshi, } \\
\text { migrant, working in } \\
\text { agriculture, children, } \\
\text { managerial } \\
\end{array}$ & $\begin{array}{l}\text { Individual: Age, sex, } \\
\text { ethnicity \& education. } \\
\\
\text { Household level: net } \\
\text { household income, } \\
\text { household size, tenure, } \\
\text { employment }\end{array}$ & $\begin{array}{c}\text { No statistically significant } \\
\text { neigjhbourhood level variance in } \\
\text { CMD (<1\%), } 3 \% \text { at household-level }\end{array}$ & \\
\hline
\end{tabular}




\begin{tabular}{|c|c|c|c|c|c|c|c|c|c|}
\hline $\begin{array}{l}\text { Study ID \& } \\
\text { Setting }\end{array}$ & $\begin{array}{l}\text { Outcome \& } \\
\text { Instrument }\end{array}$ & $\begin{array}{l}\text { Case finding, } \\
\text { age range, } \\
\text { years }\end{array}$ & Sample size & $\begin{array}{c}\text { Definition of } \\
\text { neighbourhood }\end{array}$ & $\begin{array}{l}\text { Timing of } \\
\text { exposure }\end{array}$ & $\begin{array}{c}\text { Area-levels } \\
\text { measures }\end{array}$ & $\begin{array}{l}\text { Individual-level } \\
\text { measures }\end{array}$ & Findings & Comments \\
\hline $\begin{array}{l}\text { Weich et a } 1^{147} \\
\text { (2005) } \\
\text { UK }\end{array}$ & $\begin{array}{l}\text { Common } \\
\text { Mental } \\
\text { Disorders } \\
\text { GHQ-12 } \\
\text { [point } \\
\text { prevalence] }\end{array}$ & $\begin{array}{l}\text { Survey (1991-2) } \\
\begin{array}{l}\text { Age: } 16-74 \\
\text { years }\end{array}\end{array}$ & $\begin{array}{l}\mathrm{N}=5,809 \\
\text { (onset analyses) } \\
\mathrm{N}=1850 \text { (for } \\
\text { episode } \\
\text { maintenance } \\
\text { analyses) }\end{array}$ & $\begin{array}{l}\text { Electoral wards } \\
\text { ( 2000 people) }\end{array}$ & $\begin{array}{l}\text { At time of } \\
\text { survey }\end{array}$ & $\begin{array}{c}\text { Socio-economic } \\
\text { deprivation (Carstairs } \\
\text { index) }\end{array}$ & $\begin{array}{l}\text { Age, sex, marital status, } \\
\text { ethnicity, education, } \\
\text { employment status, } \\
\text { financial strain \& current } \\
\text { physical health. } \\
\text { Household level: } \\
\text { structural housing } \\
\text { problems, household } \\
\text { income, car access, } \\
\text { tenure, social class, } \\
\text { overcrowding \& } \\
\text { household typ }\end{array}$ & $\begin{array}{c}\text { No significant variance at area-level } \\
\text { on onset or maintenance of CMD. No } \\
\text { association with deprivation after } \\
\text { adjusting for HH \& individual-level } \\
\text { variables }\end{array}$ & \\
\hline $\begin{array}{l}\text { Skapinakis et a| }{ }^{153} \\
\text { (2005) } \\
\text { UK }\end{array}$ & $\begin{array}{l}\text { Common } \\
\text { Mental } \\
\text { Disorders } \\
\text { (SF-36) } \\
\text { [point } \\
\text { prevalence] }\end{array}$ & $\begin{array}{l}\text { Survey } \\
\begin{array}{l}\text { Age: } 18 \text { years or } \\
\text { over }\end{array} \\
\text { Years: } 1998\end{array}$ & $\begin{array}{l}\text { N/A (circa } \\
27,000)\end{array}$ & Electoral division & $\begin{array}{l}\text { At time of } \\
\text { survey }\end{array}$ & Area-level deprivation & $\begin{array}{l}\text { Age, sex, marital status, } \\
\text { employment status, } \\
\text { social class }\end{array}$ & $\begin{array}{c}1.5 \% \text { variance explained at area level } \\
\text { in null-model reduced to } 0.6 \% \text { in full } \\
\text { model accounting for individual } \\
\text { characteristics \& regional deprivation. } \\
\text { Both significant. Deprivation } \\
\text { associated with greater risk of CMD } \\
\text { after accounting for individual level } \\
\text { variables } \\
\end{array}$ & \\
\hline $\begin{array}{l}\text { Veenstra et al } \\
\text { (2005) } \\
\text { Canada }{ }^{172}\end{array}$ & $\begin{array}{l}\text { Depressive } \\
\text { symptoms } \\
\text { 11-item } \\
\text { questionnaire } \\
\text { (Chronbach's } \\
\text { alpha: 0.8) }\end{array}$ & $\begin{array}{l}\text { Survey } \\
\text { Age: } 18+ \\
\text { Years: } 2002\end{array}$ & $\mathrm{~N}=1,355$ & $\begin{array}{c}\text { Census } \\
\text { metropolitan areas }\end{array}$ & $\begin{array}{l}\text { At time of } \\
\text { survey }\end{array}$ & $\begin{array}{l}\text { Internal \& external built } \\
\text { environment, social } \\
\text { capital \& neighbourhood } \\
\text { SES }\end{array}$ & $\begin{array}{l}\text { Age, sex, ethnicity, } \\
\text { income, education, } \\
\text { community trust, } \\
\text { political trust, } \\
\text { participation in } \\
\text { voluntary association }\end{array}$ & $\begin{array}{l}\text { More public spaces per capita was } \\
\text { associated with higher scores on the } \\
\text { depressive symptoms scale. } 2.1 \% \text { of } \\
\text { variance (significant) explained at } \\
\text { area level in null-model, } 1.9 \% \text { in } \\
\text { multivariable model (significance not } \\
\text { reported) }\end{array}$ & $\begin{array}{l}\text { Community \& } \\
\text { political trust } \\
\text { were associated } \\
\text { with fewer } \\
\text { symptoms }\end{array}$ \\
\hline $\begin{array}{l}\text { Galea et al (2005) } \\
\text { USA }^{166}\end{array}$ & $\begin{array}{c}\text { Major } \\
\text { depression } \\
\text { NWS } \\
\text { depression } \\
\text { module (DSM- } \\
\text { IV) } \\
\text { [lifetime/6- } \\
\text { month } \\
\text { prevalence] }\end{array}$ & $\begin{array}{l}\text { Survey } \\
\text { Age: } 18 \text { or over } \\
\text { Years: } 2002\end{array}$ & $N=1,355$ & $\begin{array}{l}59 \text { community } \\
\text { districts in New York } \\
\text { City }\end{array}$ & $\begin{array}{l}\text { At tiem of } \\
\text { survey }\end{array}$ & $\begin{array}{l}\text { Internal built } \\
\text { environment, external } \\
\text { built environment, } \\
\text { neighbourhood income }\end{array}$ & $\begin{array}{l}\text { Age, sex, ethnicity, } \\
\text { income }\end{array}$ & $\begin{array}{l}\text { In adjusted models, individuals living } \\
\text { in neighbourhoods with poorer built } \\
\text { environment were more likely to } \\
\text { report six-month \& lifetime } \\
\text { prevalence of depression. }\end{array}$ & $\begin{array}{c}\text { Survey } \\
\text { conducted soon } \\
\text { after } 9 / 11 \\
\text { World Trade } \\
\text { Centre terrorist } \\
\text { attacks }\end{array}$ \\
\hline
\end{tabular}




\begin{tabular}{|c|c|c|c|c|c|c|c|c|c|}
\hline $\begin{array}{l}\text { Study ID \& } \\
\text { Setting }\end{array}$ & $\begin{array}{l}\text { Outcome \& } \\
\text { Instrument }\end{array}$ & $\begin{array}{l}\text { Case finding, } \\
\text { age range, } \\
\text { years }\end{array}$ & Sample size & $\begin{array}{c}\text { Definition of } \\
\text { neighbourhood }\end{array}$ & $\begin{array}{l}\text { Timing of } \\
\text { exposure }\end{array}$ & $\begin{array}{l}\text { Area-levels } \\
\text { measures }\end{array}$ & $\begin{array}{l}\text { Individual-level } \\
\text { measures }\end{array}$ & Findings & Comments \\
\hline $\begin{array}{l}\text { Lofors et al }{ }^{157} \\
\text { (2006) } \\
\text { Sweden }\end{array}$ & $\begin{array}{c}\text { Anxiety } \\
\text { (self-reported) } \\
\text { [point } \\
\text { prevalence] }\end{array}$ & $\begin{array}{l}\text { Survey } \\
\text { Age: } 25-64 \\
\text { Years: } 1995- \\
2002 \\
\end{array}$ & $\mathrm{~N}=30,884$ & $\begin{array}{l}\text { SAMS (small area } \\
\text { market statistics; } \\
\sim 2000 \text { people in } \\
\text { Stockholm, } \sim 1000 \\
\text { people elsewhere) }\end{array}$ & $\begin{array}{l}\text { At time of } \\
\text { survey }\end{array}$ & $\begin{array}{c}\text { \% individuals with } \\
\text { income lower than } \\
\text { national average, } \\
\text { neighbourhoods quartiles }\end{array}$ & $\begin{array}{l}\text { Age, sex, marital status, } \\
\text { immigrant status, } \\
\text { employment, social } \\
\text { network, housing tenure }\end{array}$ & $\begin{array}{l}\text { Higher risk (odds) of anxiety when } \\
\text { moving from least to most deprived } \\
\text { neighbourhood, but not significant } \\
\text { when adjusting for individual } \\
\text { measures of SES. }\end{array}$ & \\
\hline $\begin{array}{l}\text { Fone \& } \\
\text { Dunstan }{ }^{154}(2006) \\
\text { UK }\end{array}$ & $\begin{array}{l}\text { Common } \\
\text { Mental } \\
\text { Disorders } \\
\text { (SF-36) } \\
\text { [point } \\
\text { prevalence] }\end{array}$ & $\begin{array}{l}\text { Survey } \\
\text { Age: } 14-74 \\
\text { years } \\
\text { Years: } 1998\end{array}$ & $N=24,975$ & Electoral division & $\begin{array}{l}\text { At time of } \\
\text { survey }\end{array}$ & $\begin{array}{l}\text { Townsend deprivation } \\
\text { score }\end{array}$ & $\begin{array}{l}\text { Age, sex, social class, } \\
\text { economic inactivity, } \\
\text { occupational status, } \\
\text { marital status, whether } \\
\text { the person is a carer, } \\
\text { housing tenure }\end{array}$ & $\begin{array}{l}\text { 1.3\% of CMD variance explained at } \\
\text { area-level in the null-model. Adding } \\
\text { compositional variables reduced } \\
\text { variance to } 0.5 \% \text {, which remained } \\
\text { significant. Both area-level \& } \\
\text { individual deprivation associated with } \\
\text { poorer mental health, but greater } \\
\text { effect in economically inactive } \\
\text { individuals }\end{array}$ & \\
\hline $\begin{array}{l}\text { Matheson et al }{ }^{170} \\
\text { (2006) } \\
\text { Canada }\end{array}$ & $\begin{array}{l}\text { Depression } \\
\text { CES-D } \\
\text { (short form) } \\
\text { [point } \\
\text { prevalence] }\end{array}$ & $\begin{array}{l}\text { Survey } \\
\text { Age: } 18-74 \\
\text { Years: } 2001- \\
2001 \text { \& 2003- } \\
2004\end{array}$ & $N=56,428$ & $\begin{array}{l}\text { Census tracts (range } \\
2500-8000 \text { people) }\end{array}$ & $\begin{array}{l}\text { At time of } \\
\text { survey }\end{array}$ & $\begin{array}{l}18 \text { neighbourhood } \\
\text { characteristics grouped } \\
\text { into } 4 \text { factors: residential } \\
\text { instability; material } \\
\text { deprivation; dependency; } \\
\text { ethnic diversity }\end{array}$ & $\begin{array}{c}\text { Age, sex, marital status, } \\
\text { education, visible ethnic } \\
\text { minority }\end{array}$ & $\begin{array}{l}\text { Material deprivation \& residential } \\
\text { stability associated with depression } \\
\text { after adjustment for other } \\
\text { characteristics }\end{array}$ & $\begin{array}{c}\text { No control for } \\
\text { household level } \\
\text { characteristics }\end{array}$ \\
\hline $\begin{array}{l}\text { Guite et a } 1^{143} \\
\text { (2006) } \\
\text { UK }\end{array}$ & $\begin{array}{c}\text { Common } \\
\text { Mental } \\
\text { Disorders } \\
\text { SF-36 }\end{array}$ & $\begin{array}{l}\text { Survey } \\
\text { Age: } 18+ \\
\text { Years: N/A }\end{array}$ & $\mathrm{N}=1,012$ & $\begin{array}{l}\text { LSOA (lower super } \\
\text { output area census } \\
\text { tracts) }\end{array}$ & $\begin{array}{l}\text { At time of } \\
\text { survey }\end{array}$ & $\begin{array}{l}\text { Quality of internal (heat, } \\
\text { light, noise, damp \& } \\
\text { draughts) \& external built } \\
\text { environment, population } \\
\text { density, long-term } \\
\text { limiting illness, } \\
\text { general health, crime } \\
\text { level }\end{array}$ & $\begin{array}{c}\text { Age, sex, } \\
\text { ethnicity, residential } \\
\text { stability, household size, } \\
\text { housing type \& tenure, } \\
\text { housing benefit, rent } \\
\text { arrears, requesting re- } \\
\text { housing }\end{array}$ & $\begin{array}{l}\text { Damp,; not liking residential area; } \\
\text { noise; overcrowding; dissatisfaction } \\
\text { with green spaces, community } \\
\text { facilities \& social facilities; feeling } \\
\text { unsafe; presence of needles/syringes; } \\
\text { lack of spaces where people can } \\
\text { interact were all associated with } \\
\text { higher CMD risk (odds) when entered } \\
\text { individually in multivariable models }\end{array}$ & \\
\hline $\begin{array}{l}\text { Dupere \& } \\
\text { Perkins }^{167} \\
(2007) \\
\text { USA }\end{array}$ & $\begin{array}{l}\text { Depression } \\
\text { (CES-D) } \\
\text { [point } \\
\text { prevalence] } \\
\\
\text { Anxiety } \\
\text { (STAI) } \\
\text { [point } \\
\text { prevalence] }\end{array}$ & $\begin{array}{c}\text { Survey } \\
\text { Years: } 1987\end{array}$ & $\mathrm{~N}=412$ & $\begin{array}{l}\text { Empirically derived } \\
\text { based on } \\
\text { respondents' } \\
\text { definitions }\end{array}$ & $\begin{array}{l}\text { At time of } \\
\text { survey }\end{array}$ & $\begin{array}{l}\text { Fear of crime, civic } \\
\text { participation, informal } \\
\text { ties and \% of people with } \\
\text { characteristics measured } \\
\text { at the individual level in } \\
\text { neighbourhoods grouped } \\
\text { in } 5 \text { categories: } \\
\text { advantaged to } \\
\text { disadvantaged }\end{array}$ & $\begin{array}{l}\text { Age, sex, ethnicity, } \\
\text { household income, } \\
\text { education, } \\
\text { unemployment, single } \\
\text { parenthood, residential } \\
\text { stability, personal stress, } \\
\text { perceived social support }\end{array}$ & $\begin{array}{l}\text { Depression: no associations found } \\
\text { Anxiety: Lower in middle /middle- } \\
\text { high advantage neighbourhoods \& } \\
\text { those with higher residential stability } \\
\text { after multivariable adjustment }\end{array}$ & $\begin{array}{l}\text { Multilevel } \\
\text { models for } \\
\text { depression not } \\
\text { reported in } \\
\text { text/table }\end{array}$ \\
\hline
\end{tabular}




\begin{tabular}{|c|c|c|c|c|c|c|c|c|c|}
\hline $\begin{array}{l}\text { Study ID \& } \\
\text { Setting }\end{array}$ & $\begin{array}{l}\text { Outcome \& } \\
\text { Instrument }\end{array}$ & $\begin{array}{l}\text { Case finding, } \\
\text { age range, } \\
\text { years }\end{array}$ & Sample size & $\begin{array}{c}\text { Definition of } \\
\text { neighbourhood }\end{array}$ & $\begin{array}{l}\text { Timing of } \\
\text { exposure }\end{array}$ & $\begin{array}{c}\text { Area-levels } \\
\text { measures }\end{array}$ & $\begin{array}{l}\text { Individual-level } \\
\text { measures }\end{array}$ & Findings & Comments \\
\hline $\begin{array}{l}\text { Galea et al }{ }^{168} \\
\text { (2007) } \\
\text { USA }\end{array}$ & $\begin{array}{l}\text { Depression } \\
\text { SCID-III } \\
\text { incidence }\end{array}$ & $\begin{array}{l}\text { Telephone } \\
\text { survey in } 2002+ \\
\text { follow up at } 6 \\
\text { and } 18 \text { months } \\
\text { age } \geq 18 \text { years }\end{array}$ & $\begin{array}{c}\mathrm{N}=1,570 / 1220 \\
\text { at } \mathrm{FU}\end{array}$ & $\begin{array}{l}59 \text { Community } \\
\text { districts in NYC }\end{array}$ & At diagnosis & $\begin{array}{l}\text { Area-level SES based on } \\
2000 \text { Census data }\end{array}$ & $\begin{array}{l}\text { Age, sex, ethnicity, past } \\
\text { 6-month depression, } \\
\text { traumatic events } \\
\text { exposure, income, } \\
\text { education, marital } \\
\text { status, social support, } \\
\text { stressors }\end{array}$ & $\begin{array}{l}\text { 18-month cumulative incidence of } \\
\text { depression was } 19.4 \text { vs. } 10.5 \text { per } 100 \\
\text { persons in more } c f . \text { less } \\
\text { disadvantaged neighbourhoods. } \\
\text { Depression risk was doubled in } \\
\text { disadvantaged neighbourhoods, after } \\
\text { adjusting for individual-level } \\
\text { confounders }\end{array}$ & $\begin{array}{l}\text { Response rate } \\
\quad 56 \% \\
\text { (Over-sampled } \\
\text { residents close } \\
\text { to World Trade } \\
\text { Centre) }\end{array}$ \\
\hline $\begin{array}{l}\text { Lofors et al }{ }^{64} \\
\text { (2007) } \\
\text { Sweden }\end{array}$ & $\begin{array}{l}\text { Depression } \\
\text { Hospital } \\
\text { Diagnosis ICD- } \\
\text { 9/ICD-10 } \\
\text { Incidence } \\
\end{array}$ & $\begin{array}{l}\text { Psychiatric } \\
\text { registers } \\
\text { Age 25-64 } \\
\text { years: 1997- } \\
\text { 1999) }\end{array}$ & $\begin{array}{l}\text { Sample }=4.5 \mathrm{~m} \\
\text { Swedish } \\
\text { citizens. Cases = } \\
10,930\end{array}$ & $\begin{array}{l}\text { Clusters of small } \\
\text { area neighbourhood } \\
\text { units }\end{array}$ & At diagnosis & $\begin{array}{l}\text { Linking social capital } \\
\text { (voting participation), } \\
\text { neighbourhood } \\
\text { deprivation }\end{array}$ & $\begin{array}{l}\text { Age, sex, housing } \\
\text { tenure, education, } \\
\text { employment, country of } \\
\text { birth, marital status }\end{array}$ & $\begin{array}{c}\text { Between } 1.7 \% \text { (women) \& } 2.5 \% \\
\text { (men) of total variance explained at } \\
\text { neighbourhood level. In multivariable } \\
\text { models, deprivation, but not low } \\
\text { levels of social capital associated with } \\
\text { risk of depression }\end{array}$ & \\
\hline $\begin{array}{l}\text { Stockdale } \\
\text { (2007) } \\
\text { USA }\end{array}$ & $\begin{array}{l}\text { Common } \\
\text { mental } \\
\text { disorders } \\
\text { (CIDI- short } \\
\text { form) } \\
\text { [point } \\
\text { prevalence] }\end{array}$ & $\begin{array}{l}\text { Survey } \\
\text { Age: mean age } \\
48 \text { years } \\
\text { Years: }\end{array}$ & $N=12,716$ & Census tract & $\begin{array}{l}\text { At time of } \\
\text { survey }\end{array}$ & $\begin{array}{l}\text { Neighbourhood SES, } \\
\text { density of outlets selling } \\
\text { alcohol, density of } \\
\text { mental health/ alcohol/ } \\
\text { drug facilities, } \\
\text { neighbourhood violent } \\
\text { crime arrest rate, church } \\
\text { density, average } \\
\text { household occupancy }\end{array}$ & $\begin{array}{l}\text { Age, sex, ethnicity. } \\
\text { income, education, } \\
\text { experience of witnessing } \\
\text { violence in past year, } \\
\text { residential stability }\end{array}$ & $\begin{array}{l}\text { No evidence of area-level effect on } \\
\text { risk (odds) of depressive symptoms }\end{array}$ & \\
\hline $\begin{array}{l}\text { Stafford et al }{ }^{149} \\
(2008) \\
\text { UK }\end{array}$ & $\begin{array}{l}\text { Common } \\
\text { Mental } \\
\text { Disorder } \\
\text { GHQ-12 } \\
\text { [point } \\
\text { prevalence] }\end{array}$ & $\begin{array}{l}\text { Survey } \\
\text { Age: } \\
\text { Years: 1994- } \\
\text { 1995 \& 1997- } \\
\quad 1999\end{array}$ & $\mathrm{~N}=9,082$ & $\begin{array}{l}\text { Census ward } \\
\text { (England) } \\
\text { Postcode ward } \\
\text { (Scotland) }\end{array}$ & $\begin{array}{l}\text { At time of } \\
\text { survey }\end{array}$ & $\begin{array}{l}\text { Social capital (family ties, } \\
\text { friendship ties, } \\
\text { associational } \\
\text { membership, integration } \\
\text { in society, trust, } \\
\text { attachment to } \\
\text { neighbourhood, } \\
\text { tolerance of others, } \\
\text { reciprocity) \& deprivation } \\
\text { (Carstairs index) }\end{array}$ & $\begin{array}{l}\text { Individual levels: age, } \\
\text { gender, social class } \\
\text { Household level: } \\
\text { deprivation score. }\end{array}$ & $\begin{array}{l}\text { No association between social capital } \\
\text { measures \& CMD in adjusted models. } \\
\text { For people living in deprived areas, } \\
\text { lower social capital was associated } \\
\text { with higher CMD risk (odds) }\end{array}$ & \\
\hline $\begin{array}{l}\text { Ahern et al (2011) } \\
\text { USA }^{179}\end{array}$ & $\begin{array}{l}\text { Major } \\
\text { depression } \\
\text { (unspecified } \\
\text { prevalence) } \\
\text { (PHQ-9) }\end{array}$ & $\begin{array}{l}\text { Phone survey } \\
\text { Age; } 18 \text { or over } \\
\text { Years } 2005\end{array}$ & $\mathrm{~N}=3,946$ & $\begin{array}{l}59 \text { community } \\
\text { districts in New York } \\
\text { City }\end{array}$ & $\begin{array}{l}\text { At time of } \\
\text { survey }\end{array}$ & $\begin{array}{l}\text { Neighbourhood collective } \\
\text { efficacy, social cohesion, } \\
\text { informal social control }\end{array}$ & $\begin{array}{l}\text { Age, sex, marital status, } \\
\text { ethnicity, birthplace, } \\
\text { main language, income, } \\
\text { education, length of } \\
\text { time in neighbourhood, } \\
\text { unemployment, illness, } \\
\text { financial problems }\end{array}$ & $\begin{array}{l}\text { Low neighbourhood collective } \\
\text { efficacy associated with higher risk of } \\
\text { depression after adjustment for other } \\
\text { factors }\end{array}$ & $\begin{array}{l}49 \% \text { response } \\
\quad \text { rate }\end{array}$ \\
\hline
\end{tabular}




\begin{tabular}{|c|c|c|c|c|c|c|c|c|c|}
\hline $\begin{array}{l}\text { Study ID \& } \\
\text { Setting }\end{array}$ & $\begin{array}{l}\text { Outcome \& } \\
\text { Instrument }\end{array}$ & $\begin{array}{l}\text { Case finding, } \\
\text { age range, } \\
\text { years }\end{array}$ & Sample size & $\begin{array}{c}\text { Definition of } \\
\text { neighbourhood }\end{array}$ & $\begin{array}{l}\text { Timing of } \\
\text { exposure }\end{array}$ & $\begin{array}{l}\text { Area-levels } \\
\text { measures }\end{array}$ & $\begin{array}{l}\text { Individual-level } \\
\text { measures }\end{array}$ & Findings & Comments \\
\hline $\begin{array}{l}\text { Vallée et al (2011) } \\
\text { France }^{158}\end{array}$ & $\begin{array}{l}\text { Depression } \\
\text { Current } \\
\text { prevalence } \\
\text { (MINI) }\end{array}$ & Years 2005 & $\mathrm{~N}=3,023$ & $\begin{array}{l}50 \text { Census blocks in } \\
\text { Paris and suburbs, } \\
\text { and perceived } \\
\text { neighbourhood }\end{array}$ & $\begin{array}{l}\text { At time of } \\
\text { survey }\end{array}$ & $\begin{array}{l}\text { Activity space in } \\
\text { neighbourhood, } \\
\text { neighbourhood } \\
\text { deprivation (self- } \\
\text { reported, aggregate } \\
\text { measure from } \\
\text { respondents, actual } \\
\text { deprivation) } \\
\text { neighbourhood location } \\
\text { (inner city, suburbs) }\end{array}$ & $\begin{array}{l}\text { Age, sex, nationality, } \\
\text { edication, occupational } \\
\text { and employment status, } \\
\text { marital status, functional } \\
\quad \text { limitation }\end{array}$ & $\begin{array}{l}\text { People in deprived neighbourhoods } \\
\text { were significantly more depressed } \\
\text { than those in advantaged } \\
\text { neighbourhoods, especially when } \\
\text { activity spaces were limited } \\
\text { Initial spatial variance in depression } \\
\text { accounted for by neighbourhood } \\
\text { factors }\end{array}$ & \\
\hline $\begin{array}{l}\text { Beyer et al }{ }^{136} \\
\text { (2014) } \\
\text { USA }\end{array}$ & $\begin{array}{l}\text { Common } \\
\text { Mental } \\
\text { Disorders } \\
\text { (unspecified } \\
\text { prevalence) } \\
\text { (DASS) }\end{array}$ & $\begin{array}{l}\text { Survey } \\
\text { Age: } 21-74 \\
\text { Years: } 2008- \\
\quad 2011\end{array}$ & $N=2,479$ & $\begin{array}{l}\text { Wisconsin Census } \\
\text { Block groups } \\
\text { [600-3000 people] }\end{array}$ & $\begin{array}{l}\text { At time of } \\
\text { survey }\end{array}$ & $\begin{array}{l}\text { Green spaces, \% tree } \\
\text { canopy, urbanicity, } \\
\text { population density, } \\
\text { median household } \\
\text { income below poverty, } \\
\text { residential instability, \% } \\
\text { owner occupied } \\
\text { households, \% } \\
\text { unemployed, ethnic } \\
\text { segregation. } \\
\end{array}$ & $\begin{array}{l}\text { Age, sex, ethnicity, } \\
\text { marital status, } \\
\text { education, household } \\
\text { income, occupational } \\
\text { status, health insurance }\end{array}$ & $\begin{array}{l}\text { Higher \% green spaces associated } \\
\text { with better mental health outcomes } \\
\text { after adjustment for all other } \\
\text { variables } \\
\text { Other social \& economic aspects of } \\
\text { neighbourhood also associated with } \\
\text { depression, anxiety \& stress }\end{array}$ & \\
\hline $\begin{array}{l}\text { Jokela }{ }^{173} \\
\text { (2014) } \\
\text { Australia }\end{array}$ & $\begin{array}{l}\text { Mental Health } \\
\text { (unspecified } \\
\text { prevalence) } \\
\text { (mental health } \\
\text { short form, SF- } \\
\quad 36 \text { ) }\end{array}$ & $\begin{array}{l}\text { Longitudinal } \\
\text { Survey over } 10 \\
\text { years } \\
\text { Age: } \\
\text { Years: }\end{array}$ & $\mathrm{N}=20,012$ & $\begin{array}{c}\text { Statistical local } \\
\text { areas (median } \\
\text { population } n=5,908 \text { ) }\end{array}$ & $\begin{array}{l}\text { Repeated } \\
\text { measuremen } \\
\text { ts at } \\
\text { baselines } \\
\text { and follow } \\
\text { ups. }\end{array}$ & $\begin{array}{l}\text { Index of neighbourhood } \\
\text { disadvantage; } \\
\text { neighbourhood } \\
\text { remoteness }\end{array}$ & $\begin{array}{l}\text { Age, sex, country of } \\
\text { birth, smoking, alcohol, } \\
\text { physical activity, } \\
\text { neighbourhood } \\
\text { dissatisfaction \& } \\
\text { problems }\end{array}$ & $\begin{array}{l}\text { Association between neighbourhood } \\
\text { disadvantage } \& \text { poorer mental health } \\
\text { explained by individual-level } \\
\text { characteristics. Neighbourhood } \\
\text { remoteness was associated with } \\
\text { better mental health }\end{array}$ & $\begin{array}{l}\text { Participants } \\
\text { moving to more } \\
\text { disadvantaged } \\
\text { areas had } \\
\text { poorer mental } \\
\text { health, } \\
\text { supporting } \\
\text { social drift } \\
\text { hypothesis } \\
\end{array}$ \\
\hline $\begin{array}{l}\text { Jones-Rounds et } \\
\text { al'159 } \\
\text { (2014) } \\
\text { Multiple } \\
\text { European cities }\end{array}$ & $\begin{array}{l}\text { Psychological } \\
\text { wellbeing } \\
\text { Point } \\
\text { prevalence } \\
\text { (6 questions } \\
\text { capturing } \\
\text { symptoms of } \\
\text { depression \& } \\
\text { anxiety) } \\
\end{array}$ & $\begin{array}{l}\text { Survey } \\
\text { Age: N/A } \\
\text { Years: } 2002- \\
\quad 2003\end{array}$ & $N=5,605$ & Not-specified & $\begin{array}{l}\text { At time of } \\
\text { survey }\end{array}$ & Neighbourhood quality & $\begin{array}{c}\text { Individual level: SES, } \\
\text { employment status, sex } \\
\text { \& marital status, housing } \\
\text { quality } \\
\text { Household level: size, } \\
\text { composition, highest } \\
\text { educational level of any } \\
\text { member, number of } \\
\text { people working full time, } \\
\text { people over } 60\end{array}$ & $\begin{array}{l}\text { Housing \& neighbourhood quality } \\
\text { predicted psychological well-being in } \\
\text { adjusted models. Effect of } \\
\text { neighbourhood quality less } \\
\text { pronounced at higher levels of } \\
\text { housing quality }\end{array}$ & \\
\hline
\end{tabular}




\begin{tabular}{|c|c|c|c|c|c|c|c|c|c|}
\hline $\begin{array}{l}\text { Study ID \& } \\
\text { Setting }\end{array}$ & $\begin{array}{l}\text { Outcome \& } \\
\text { Instrument }\end{array}$ & $\begin{array}{l}\text { Case finding, } \\
\text { age range, } \\
\text { years }\end{array}$ & Sample size & $\begin{array}{c}\text { Definition of } \\
\text { neighbourhood }\end{array}$ & $\begin{array}{l}\text { Timing of } \\
\text { exposure }\end{array}$ & $\begin{array}{l}\text { Area-levels } \\
\text { measures }\end{array}$ & $\begin{array}{l}\text { Individual-level } \\
\text { measures }\end{array}$ & Findings & Comments \\
\hline $\begin{array}{l}\text { Erdem et a }\left.\right|^{156} \\
\text { (2015) } \\
\text { The Netherlands }\end{array}$ & $\begin{array}{l}\text { Psychological } \\
\text { distress } \\
\text { Point } \\
\text { prevalence } \\
\text { (Kessler-10) }\end{array}$ & $\begin{array}{l}\text { Survey } \\
\text { Age: } 16 \text { or over } \\
\text { Years: } 2008\end{array}$ & $N=18,173$ & $\begin{array}{l}\text { City district (average } \\
4000 \text { people) }\end{array}$ & $\begin{array}{l}\text { At time of } \\
\text { survey }\end{array}$ & $\begin{array}{l}\text { Neighbourhood SES } \\
\text { (income, work and level } \\
\text { of education), } \\
\text { neighbourhood green } \\
\text { space, urbanicity \& home } \\
\text { maintenance, social } \\
\text { cohesion }\end{array}$ & $\begin{array}{c}\text { Age, sex, ethnic } \\
\text { background, marital } \\
\text { status \& years in current } \\
\text { city, education, } \\
\text { occupation \& financial } \\
\text { difficulties }\end{array}$ & $\begin{array}{l}\text { In univariable model } 2.87 \% \text { of } \\
\text { variance explained at neighbourhood } \\
\text { level, but reduced to } 0.25 \% \text { when } \\
\text { individual variables included } \\
\\
\text { Higher neighbourhood social } \\
\text { cohesion associated with lower } \\
\text { psychological distress after } \\
\text { adjustment }\end{array}$ & \\
\hline $\begin{array}{l}\text { Gariepy et al }{ }^{171} \\
\text { (2015) } \\
\text { Canada }\end{array}$ & $\begin{array}{l}\text { Episodes of } \\
\text { depression } \\
\text { Point } \\
\text { prevalence } \\
\text { (CIDI short } \\
\text { form) }\end{array}$ & $\begin{array}{c}\text { Survey } \\
\text { Age: N/A } \\
\text { (average } 42 \text { at } \\
\text { baseline) } \\
\text { Years: } 2000- \\
2011\end{array}$ & $N=7,114$ & $\begin{array}{l}500 \mathrm{~m} \text { radius buffer } \\
\text { around centre of } \\
\text { postal code of each } \\
\text { participant }\end{array}$ & $\begin{array}{l}\text { At time of } \\
\text { survey }\end{array}$ & $\begin{array}{l}\text { Density of businesses, } \\
\text { parks \& recreational } \\
\text { facilities }\end{array}$ & $\begin{array}{l}\text { Age, sex, marital status, } \\
\text { education income } \\
\text { adequacy, family history } \\
\text { of depression, chronic } \\
\text { condition, childhood life } \\
\text { events }\end{array}$ & $\begin{array}{l}\text { Presence of parks, healthy food } \\
\text { stores, fast food restaurants \& health } \\
\text { services associated with lower } \\
\text { probability of depression episode } \\
\text { among people in low depression } \\
\text { trajectory. Parks were associated with } \\
\text { lower probability of depression } \\
\text { episode in people in the moderate } \\
\text { depression trajectory } \\
\end{array}$ & \\
\hline \multicolumn{10}{|l|}{ LAMIC } \\
\hline $\begin{array}{l}\text { Dias Porto } \\
\text { Chiavegatto Filho } \\
\text { et al }\left.\right|^{174} \\
\text { (2013) } \\
\text { Brazil }\end{array}$ & $\begin{array}{l}\text { Depression \& } \\
\text { anxiety } \\
\text { (CIDI) } \\
\text { [point } \\
\text { prevalence] }\end{array}$ & $\begin{array}{l}\text { Survey } \\
\text { Age: } 18+ \\
\text { Years: } 2004- \\
2005 \\
\end{array}$ & $N=3,542$ & Sao Paolo boroughs & $\begin{array}{l}\text { At the time } \\
\text { of survey }\end{array}$ & $\begin{array}{l}\text { Income inequality (Gini } \\
\text { Coefficient) }\end{array}$ & $\begin{array}{l}\text { Age, sex, education, } \\
\text { income, marital status }\end{array}$ & $\begin{array}{l}\text { In multivariable analyses, living in } \\
\text { areas with medium to high income } \\
\text { inequality associated with higher risk } \\
\text { (odds) of depression, but not anxiety. }\end{array}$ & \\
\hline $\begin{array}{l}\text { Tomita \& Burns }{ }^{175} \\
\text { (2013) } \\
\text { South Africa }\end{array}$ & $\begin{array}{l}\text { Depression } \\
\text { (CES-D) } \\
\text { [point } \\
\text { prevalence] }\end{array}$ & $\begin{array}{l}\text { Survey } \\
\text { Age: 15+ } \\
\text { Years: } 2008\end{array}$ & $N=13,469$ & $\begin{array}{l}\text { Neighbourhoods } \\
\text { (non-specified) }\end{array}$ & $\begin{array}{l}\text { At the time } \\
\text { of survey }\end{array}$ & $\begin{array}{l}\text { Social capital (from } 4 \\
\text { questions on (1) support } \\
\text { network \& } \\
\text { reciprocity, (2) } \\
\text { association activity, (3) } \\
\text { collective norm \& values, } \\
\text { (4) safety) }\end{array}$ & $\begin{array}{l}\text { Civic participation, social } \\
\text { trust, age, sex, ethnicity, } \\
\text { marital status, } \\
\text { employment, education, } \\
\text { self-reported health } \\
\text { status, social class, } \\
\text { neighbourhood } \\
\text { attachment } \\
\end{array}$ & $\begin{array}{l}\text { In multivariable models lower social } \\
\text { capital was associated with higher } \\
\text { levels of depressive symptoms } \\
2.61 \% \text { of variance was attributable to } \\
\text { neighbourhood level }\end{array}$ & \\
\hline
\end{tabular}

List of abbreviations: CES-D= Center for Epidemiological Studies Depression scale; CIDI:= Composite International Diagnostic Interview ; CIS-R = Clinical Interview Schedule Revised; DASS= Depression Anxiety Stress Scales ; DIS= Diagnostic Interview Schedule; DMI = Depressive Mood Inventory; GHQ= General Health Questionnaire; HLEQ= Health and Life Experiences Questionnaire; NWS = National Women Study; PHQ-9 = Patient Health Questionnaire; SF-36= Short Form 36; STAI = State Trait Anxiety Inventory 


\subsection{Strengths and limitations}

Compared with studies of schizophrenia, sample sizes in CMD studies have generally been smaller, although these were generally adequately powered to detect any significant associations. Their reliance on cross-sectional survey based designs are well-suited to measuring prevalence in the general population, providing the sampling frame allows for adequate generalisation. These study designs also mean a large number of confounding factors can be measured at the time of the survey, offering an advantage over register-based investigations which may be limited to routinely-collected data. Such additional adjustment could explain the less pronounced association between urban environments and CMD than for schizophrenia, though further empirical work would be required in the schizophrenia literature to confirm this. Alternatively, studies of CMD typically use a broader variety of instruments to measure clinical disorder or general (often sub-clinical) psychopathology in their samples, which could lead to the observation of weaker associations overall, if exposure to social adversity was only causally important in the emergence of clinical disorders. Cross-sectional surveys have a number of inherent weaknesses; for example, people taking part in the surveys may be systematically different from those who do not, affecting (biasing) the results. In the studies we reviewed, participation rates varied from $54 \%{ }^{126}$ to $90.6 \%{ }^{180}$ in urban-rural studies and between $38 \%{ }^{143}$ and $86 \%{ }^{161}$ in neighbourhood studies, suggesting that selective participation could be an issue in some studies. A further limitation of cross-sectional studies is that exposures (i.e. urban living) and confounders are measured concomitantly with the outcome (CMD), making it impossible to infer causality from any observed association; as the adage goes, correlation does not imply causation. While cross-sectional surveys can obtain measures which happened in the past, via interview or questionnaire, the answers elicited from this type of study may be prone to recall bias. If the probability of (mis)remembering an exposure or confounder in the past is related to the participant's mental health status, this type of bias can be particularly problematic, since any observed associations may be under- or over-estimations of the true effect.

In summary, the evidence in favour of an association between contextual neighbourhood factors and CMD was weaker than for schizophrenia and other non-affective psychotic disorders. The overall variance in the distribution of CMDs was generally less than $2 \%$, with some indication that observed associations were due to residual confounding or household-level characteristics. These results suggest that compositional rather than contextual characteristics are driving any small area-level variation in CMD. Notwithstanding, most studies of CMD included here were cross-sectional, making it impossible to exclude selection biases as an explanation for the inconsistent or null findings 
observed. Further longitudinal research into the role of the neighbourhood on CMD risk would therefore appear warranted.

\section{Suicide}

Each year more than 800,000 people die by suicide, making it the second leading cause of death among young people globally. ${ }^{181}$ Suicide therefore presents a major public health issue, particularly because a large amount of research suggests that rates are unequally distributed throughout the population. Thus, they vary by gender ${ }^{182-186}$ presence of an existing mental disorder, ${ }^{187-189}$ chronic illness, ${ }^{190}$ unemployment, ${ }^{191}$ low social support and social capital ${ }^{192,193}$ and exposure to violence, abuse or trauma. ${ }^{194-198}$ While much of this research has focussed on the individual level, the distribution of these risk factors, as well as suicide rates, vary according to characteristics of geographic areas, communities, and neighbourhoods.

Investigation of the spatial distribution of suicide mortality dates back as far as the late $19^{\text {th }}$ Century, with Durkheim's seminal monograph, ${ }^{199}$ in which he first noted that suicide rates clustered geographically. He proposed that individual acts of suicide were due to forces outside of the individual, and that the geographical distribution of suicide rates could be explained by underlying patterns of social interaction and regulation. By contrast, Tarde (1903), ${ }^{200}$ argued that such patterns could be understood by imitation, where behaviours and beliefs are shared within a population. Numerous studies have subsequently investigated the spatial distribution of suicide, demonstrating that suicide mortality varies geographically. Such research allows appropriate investment in public mental health and prevention strategies, and may give further insight into the aetiology of suicidal acts. In this section, we review the main studies on suicide risk in relation to both broad rural-urban variation and specific area-level or neighbourhood differences in risk. We briefly examine whether suicide methods differ between rural and urban settings, and summarise the main hypotheses put forward to explain geographical differences in patterns of risk.

\subsection{Urban vs. rural settings}

To study how suicide rates vary between rural and urban areas, research studies have often used centralized registries, coroners' reports and death certificates as a basis for investigation. Most studies have been conducted in High Income countries, including six from Australia, ${ }^{201-206}$ four from the United States, ${ }^{207-210}$ two from Austria, ${ }^{211,212}$ three from the UK, ${ }^{213-215}$ one from Canada ${ }^{216}$ and one from New Zealand $^{217}$ (Table 5). More recently, a handful of studies have been conducted in LAMIC countries, including Taiwan, ${ }^{218}$ India, ${ }^{219}$ Belarus, ${ }^{220}$ China ${ }^{221}$ and South Korea. ${ }^{222}$ 
Table 5: Summary of literature on rural/urban differences in suicide rates (from 2000 onwards, chronologically ordered)

\begin{tabular}{|c|c|c|c|c|c|c|c|c|c|}
\hline $\begin{array}{l}\text { Study ID \& } \\
\text { setting }\end{array}$ & $\begin{array}{l}\text { Diagnostic criteria } \\
\text { \& outcome }\end{array}$ & $\begin{array}{l}\text { Case finding, age } \\
\text { range, years }\end{array}$ & $\begin{array}{l}\text { Sample } \\
\text { size \& no. } \\
\text { of cases }\end{array}$ & $\begin{array}{l}\text { Definition of spatial unit } \\
\text { (rural/urban) }\end{array}$ & $\begin{array}{l}\text { Timing of } \\
\text { urban }\end{array}$ & Findings & Higher in & Confounders & Comments \\
\hline $\begin{array}{l}\text { Wilkinson \& } \\
\text { Gunnell } \\
\text { (2006) } \\
\text { Australia }\end{array}$ & $\begin{array}{l}\text { Suicide and } \\
\text { undetermined } \\
\text { deaths } \\
\text { ICD-9 codes E950-9, } \\
\text { E980-9 except } \\
\text { E988.8 }\end{array}$ & $\begin{array}{l}\text { Australian Bureau of } \\
\text { Statistics (ABS) } \\
\text { Aged 15-34 years } \\
\text { (1988-1997) }\end{array}$ & & $\begin{array}{l}\text { Nonmetropolitan classified as } \\
\leq 20000 \text { people; metropolitan } \\
>20000 \text { people }\end{array}$ & & $\begin{array}{l}\text { Suicide rates in non-metropolitan } \\
\text { areas higher for men aged } 15-24 \\
\text { years, but lower for women aged } \\
25-34 \text { years old compared to } \\
\text { their counterparts in } \\
\text { metropolitan areas. No other } \\
\text { differences }\end{array}$ & $\begin{array}{l}\text { Rural (men 15- } \\
\text { 24), equivalent } \\
\text { (men, 25-34; } \\
\text { women 15-24), } \\
\text { urban (women } \\
\text { 25-34) }\end{array}$ & & \\
\hline $\begin{array}{l}\text { Yip et a }\left.\right|^{225} \\
(2000) \\
\text { China }\end{array}$ & & $\begin{array}{l}\text { China's Ministry of } \\
\text { Health - Death } \\
\text { certificates issued by } \\
\text { physicians. } \\
(1991-2000)\end{array}$ & & Not specified & Not specified & $\begin{array}{l}\text { Suicide rates consistently higher } \\
\text { in rural } c f . \text { urban areas for men \& } \\
\text { women. Overall rates decreased } \\
\text { over time, with an interplay of } \\
\text { age, gender \& region driving } \\
\text { change }\end{array}$ & Rural & Age, sex, region & $\begin{array}{l}\text { Authors suggest that rapid } \\
\text { modernization has } \\
\text { corresponded to } \\
\text { decreased suicide rates in } \\
\text { China, due in part to } \\
\text { increased standards of } \\
\text { living, education \& } \\
\text { medical care. }\end{array}$ \\
\hline $\begin{array}{l}\text { Singh \& } \\
\text { Siahpush }^{210} \\
\text { (2002) } \\
\text { USA }\end{array}$ & & $\begin{array}{l}\text { County mortality data } \\
\text { - National mortality } \\
\text { data files. } \\
\text { Aged 15+ years } \\
\text { (1970-1997) }\end{array}$ & & $\begin{array}{l}\text { Counties categorized using US } \\
\text { Department of Agriculture } \\
\text { classification based on } \\
\text { population size \& proximity to } \\
\text { metropolitan areas } \\
\text { categorised into } 10 \text { levels }\end{array}$ & $\begin{array}{l}\text { At death } \\
\text { (county-specific } \\
\text { annual suicide } \\
\text { deaths) } n=3,101 \\
\text { US counties }\end{array}$ & $\begin{array}{l}\text { Male suicide rates were higher in } \\
\text { rural areas. Gap increased over } \\
\text { time \& more pronounced in 15- } \\
24 \text { men. For women, between } \\
1970-1989 \text {, suicide rates were } \\
\text { higher in urban areas, but this } \\
\text { difference decreased over time \& } \\
\text { rates were higher in rural areas } \\
\text { by } 1995-7\end{array}$ & $\begin{array}{l}\text { Rural (men), } \\
\text { urban (women, } \\
\text { 1970-1989), } \\
\text { rural (women, } \\
1995-7)\end{array}$ & $\begin{array}{l}\text { Age-, sex- \& county- } \\
\text { specific deaths. } \\
\text { Adjusted for county- } \\
\text { level variation in } \\
\text { ethnic composition } \\
\& \text { divorce rate (as } \\
\text { indicator of social } \\
\text { disintegration) }\end{array}$ & $\begin{array}{l}\text { Classification of } \\
\text { rurality/urbanicity was } \\
\text { done in } 1993 \text { based on } \\
1990 \text { census. Criteria may } \\
\text { not be appropriate across } \\
\text { all time periods. }\end{array}$ \\
\hline $\begin{array}{l}\text { Middleton et } \\
\text { a|215 } \\
(2003) \\
\text { England \& } \\
\text { Wales }\end{array}$ & $\begin{array}{l}\text { Suicide \& } \\
\text { undetermined death } \\
\text { - ICD-9 codes E950- } \\
\text { E959 \& E980-E989, } \\
\text { excluding E988.8 }\end{array}$ & $\begin{array}{l}\text { Office for National } \\
\text { Statistics (ONS) } \\
\text { (1981-1998) }\end{array}$ & & $\begin{array}{l}9264 \text { electoral wards } \\
\text { categorized by } 2 \text { indices: (1) } \\
\text { population density (quartiles); } \\
\text { (2) population potential } \\
\text { (quartiles) - a measure of } \\
\text { geographic remoteness from } \\
\text { large settlements }\end{array}$ & $\begin{array}{l}\text { Postcode of } \\
\text { usual residence } \\
\text { at time of } \\
\text { death, linked to } \\
\text { electoral wards } \\
\text { based on } 1981 \\
\text { boundaries } \\
\end{array}$ & $\begin{array}{l}\text { Among } 15-44 \text { year olds, suicides } \\
\text { higher in remote areas. Rises in } \\
\text { rates in rural areas were more } \\
\text { related to population potential } \\
\text { than population density. }\end{array}$ & Rural & $\begin{array}{l}\text { Townsend socio- } \\
\text { economic } \\
\text { deprivation index \& } \\
\text { Congdon social } \\
\text { fragmentation index }\end{array}$ & \\
\hline $\begin{array}{l}\text { Caldwell et a }\left.\right|^{201} \\
\text { (2004) } \\
\text { Australia }\end{array}$ & $\begin{array}{l}\text { ICD-10 codes X60- } \\
\text { X84 }\end{array}$ & $\begin{array}{l}\text { Australian Bureau of } \\
\text { Statistics (ABS) } \\
\text { Aged 20+ years } \\
(1997-2000)\end{array}$ & $\mathrm{N}=10,641$ & $\begin{array}{l}\text { Metropolitan centres } \\
(\geq 100,000) \text {, rural centres } \\
(10000-99999) \\
\text { Population \& rural areas } \\
\text { (<10000 people) }\end{array}$ & & $\begin{array}{l}\text { Rates higher for men in rural } \\
\text { compared with metropolitan } \\
\text { areas. For women, only those } \\
\text { aged } 30-44 \text { had higher rates in } \\
\text { rural areas }\end{array}$ & $\begin{array}{l}\text { Rural (men, } \\
\text { women aged } \\
\text { 30-44), } \\
\text { equivalent } \\
\text { (women, other } \\
\text { ages) }\end{array}$ & & $\begin{array}{l}\text { Young men with mental } \\
\text { health disorders in rural } \\
\text { areas less likely to seek } \\
\text { professional help }\end{array}$ \\
\hline
\end{tabular}




\begin{tabular}{|c|c|c|c|c|c|c|c|c|c|}
\hline $\begin{array}{l}\text { Study ID \& } \\
\text { setting }\end{array}$ & $\begin{array}{l}\text { Diagnostic criteria } \\
\& \text { outcome }\end{array}$ & $\begin{array}{l}\text { Case finding, age } \\
\text { range, years }\end{array}$ & $\begin{array}{l}\text { Sample } \\
\text { size } \& \text { no. } \\
\text { of cases }\end{array}$ & $\begin{array}{l}\text { Definition of spatial unit } \\
\text { (rural/urban) }\end{array}$ & $\begin{array}{l}\text { Timing of } \\
\text { urban }\end{array}$ & Findings & Higher in & Confounders & Comments \\
\hline $\begin{array}{l}\text { Levin \& } \\
\text { Leyland } 214 \\
(2005) \\
\text { Scotland }\end{array}$ & $\begin{array}{l}\text { Suicides \& } \\
\text { undetermined } \\
\text { deaths. } \\
\text { ICD-9 codes E950- } \\
959.0 \text { \& E980-988.9 }\end{array}$ & $\begin{array}{l}\text { General Register } \\
\text { Office for Scotland } \\
\text { (GROS) } \\
\text { Ages 15+ years } \\
(1981-1999)\end{array}$ & & $\begin{array}{l}\text { Four groups from the Scottish } \\
\text { Household Survey rurality } \\
\text { classification. (1) Urban } \\
>10,000 \text { people; (2) Accessible } \\
\text { Rural = settlements }<10,000 \& \text { } \\
\text { within } 30 \text { min drive of } \\
\text { settlement of } \geq 10,000 \text {; (3) } \\
\text { Remote Towns = 3000-10,000 } \\
\&>30 \text { min drive of a } \\
\text { settlement of } \geq 10,000 \text {; (4) } \\
\text { Remote Rural }=<3000 \\
\text { population } \&>30 \text { min drive } \\
\text { from settlement of } \geq 10,000\end{array}$ & $\begin{array}{l}\text { Residence at } \\
\text { death }\end{array}$ & $\begin{array}{l}\text { Highest rates in remote rural } \\
\text { areas. Age- } \& \text { deprivation- } \\
\text { adjusted models showed } \\
\text { significantly greater risk of male } \\
\text { suicide in remote } \& \text { rural areas } \\
\text { relative to urban areas, but lower } \\
\text { risk of female suicide in } \\
\text { accessible rural areas }\end{array}$ & Rural (men) & $\begin{array}{l}\text { Carstairs } \\
\text { deprivation } \\
\text { indicator using car } \\
\text { ownership, low } \\
\text { social class, male } \\
\text { unemployment \& } \\
\text { overcrowding), age, } \\
\text { sex }\end{array}$ & $\begin{array}{l}\text { High divorce rates \& } \\
\text { population loss between } \\
1990-2000 \text { predicted } \\
\text { suicide rates }\end{array}$ \\
\hline $\begin{array}{l}\text { Yip et al221 } \\
\text { (2005) } \\
\text { Australia \& } \\
\text { China (Beijing) }\end{array}$ & $\begin{array}{l}\text { ICD-9 codes E950- } \\
\text { E959 }\end{array}$ & $\begin{array}{l}\text { Australia - Australian } \\
\text { Bureau of Statistics - } \\
\text { Coroner's report. } \\
\text { Beijing - Death } \\
\text { certificates \& Public } \\
\text { Security Office from } \\
\text { the Ministry of Health } \\
\text { (1991-6), }\end{array}$ & $\begin{array}{l}\text { Not } \\
\text { specified }\end{array}$ & Not specified & Not specified & $\begin{array}{l}\text { In Beijing suicide rates in rural } \\
\text { areas were nearly } 3 \text { times higher } \\
\text { than urban areas, ( } \sim 5 \text { times } \\
\text { higher for women aged } 25-34) \text {. } \\
\text { In Australia, rural male suicide } \\
\text { rate was higher than urban rate, } \\
\text { but pattern reversed for women }\end{array}$ & $\begin{array}{l}\text { Rural (Beijing: } \\
\text { men \& women, } \\
\text { Australia: men) } \\
\text { Urban } \\
\text { (Australia: } \\
\text { women) }\end{array}$ & Age, sex, region & $\begin{array}{l}\text { Authors noted that the } \\
\text { male: female suicide ratio } \\
\text { in China was less than } 1: 1 \text {, } \\
\text { but in Australia it was } 4: 1 \text {. } \\
\text { In Beijing, elderly suicide } \\
\text { rates were } 6 \text { times higher } \\
\text { than the general } \\
\text { population, but were not } \\
\text { as increased in Australia }\end{array}$ \\
\hline $\begin{array}{l}\text { Stark et a }{ }^{213} \\
(2007) \\
\text { Scotland }\end{array}$ & $\begin{array}{l}\text { Suicide or } \\
\text { undetermined cause } \\
\text { ICD-9 codes E950- } \\
\text { E959, ICD-10 codes } \\
\text { X60-X84, E980-E989, } \\
\text { Y10-Y34. }\end{array}$ & $\begin{array}{l}\text { General Register } \\
\text { Office for Scotland } \\
\text { (1981-1999) }\end{array}$ & & $\begin{array}{l}\text { Postcode sector used as proxy } \\
\text { for rurality. Population density } \\
\text { divided into quartiles. }\end{array}$ & $\begin{array}{l}\text { Death allocated } \\
\text { to area of } \\
\text { residence, } \\
\text { rather than the } \\
\text { area they died. }\end{array}$ & $\begin{array}{l}\text { Higher rate ratios in most \& least } \\
\text { densely populated quartiles. } \\
\text { Association in women varied by } \\
\text { age }- \text { no association under } 25 \\
\text { years, similar pattern to men in } \\
\text { middle age, lower rural rates in } \\
\text { older women }\end{array}$ & $\begin{array}{l}\text { Various (see } \\
\text { left) }\end{array}$ & & \\
\hline $\begin{array}{l}\text { Page et al204 } \\
\text { (2007) } \\
\text { Australia }\end{array}$ & Not specified & $\begin{array}{l}\text { Australian Bureau of } \\
\text { Statistics (ABU) } \\
\text { Aged 15+ years } \\
(1979-2003)\end{array}$ & & $\begin{array}{l}\text { Rural, remote \& Metropolitan } \\
\text { Area classification system: (1) } \\
\text { metropolitan; (2) rural areas } \\
\text { (large \& small rural centres \& } \\
\text { other rural areas); (3) remote } \\
\text { areas (remote centres \& other } \\
\text { remote areas) }\end{array}$ & & $\begin{array}{l}\text { Rural-urban differences reduced } \\
\text { over the study period, but } \\
\text { remained significant for men. } \\
\text { Female suicide rates were lower } \\
\text { in rural \& remote areas, } \\
\text { particularly for those aged } 25-34\end{array}$ & $\begin{array}{l}\text { Rural (men), } \\
\text { urban (women) }\end{array}$ & $\begin{array}{l}\text { Sex, age, country-of- } \\
\text { birth, area SES }\end{array}$ & \\
\hline $\begin{array}{l}\text { Pearce, Barnett } \\
\text { \& Jones }{ }^{217} \\
\text { (2007) } \\
\text { New Zealand }\end{array}$ & & $\begin{array}{l}\text { Ministry of Health } \\
\text { Aged 15+ years } \\
\text { (1980-2001) }\end{array}$ & $\begin{array}{l}\mathrm{N}=9,054 \\
\text { suicide } \\
\text { deaths }\end{array}$ & $\begin{array}{l}\text { Census Area Unit (CAU) ( } 2300 \\
\text { people) classified according to } \\
\text { Statistics New Zealand's } \\
\text { Urban-Rural Profile } \\
\text { Classification to create a } \\
\text { binary urban-rural variable }\end{array}$ & $\begin{array}{l}\text { Domicile code } \\
\text { (linked to CAU) } \\
\text { at death }\end{array}$ & $\begin{array}{l}\text { Higher rates in urban areas } \\
\text { (1980-1982), but equivocal by } \\
\text { 1990s. Narrowing urban/ rural } \\
\text { differential may be due to raised } \\
\text { suicide rates in more rural } \\
\text { communities over time }\end{array}$ & $\begin{array}{l}\text { Urban (1980- } \\
\text { 82), equivalent } \\
\text { (1990s) }\end{array}$ & $\begin{array}{l}\text { Sex, residential } \\
\text { domicile, age at } \\
\text { death }\end{array}$ & \\
\hline $\begin{array}{l}\text { Kapusta et al }{ }^{211} \\
\text { (2008) } \\
\text { Austria }\end{array}$ & ICD-8, ICD-9, ICD-10 & $\begin{array}{l}\text { Statistics Austria - } \\
\text { death certificates } \\
(1970-2005)\end{array}$ & 99 districts & $\begin{array}{l}\text { Five population density } \\
\text { categories }\end{array}$ & & $\begin{array}{l}\text { Ratio of rural to urban suicide } \\
\text { rates continuously increased over } \\
\text { last } 30 \text { years, indicating growing } \\
\text { risk in rural areas }\end{array}$ & Rural & $\begin{array}{l}\text { Age, sex, family } \\
\text { status \& suicide } \\
\text { method }\end{array}$ & \\
\hline
\end{tabular}




\begin{tabular}{|c|c|c|c|c|c|c|c|c|c|}
\hline $\begin{array}{l}\text { Study ID \& } \\
\text { setting }\end{array}$ & $\begin{array}{l}\text { Diagnostic criteria } \\
\& \text { outcome }\end{array}$ & $\begin{array}{l}\text { Case finding, age } \\
\text { range, years }\end{array}$ & $\begin{array}{l}\text { Sample } \\
\text { size } \& \text { no. } \\
\text { of cases }\end{array}$ & $\begin{array}{l}\text { Definition of spatial unit } \\
\text { (rural/urban) }\end{array}$ & $\begin{array}{l}\text { Timing of } \\
\text { urban }\end{array}$ & Findings & Higher in & Confounders & Comments \\
\hline $\begin{array}{l}\text { Razvodovsky \& } \\
\text { Stickley220 } \\
\text { (2009) } \\
\text { Belarus }\end{array}$ & & $\begin{array}{l}\text { Belarus Ministry of } \\
\text { Statistics } \\
\text { Ages 15+ years } \\
(1990-2005)\end{array}$ & & $\begin{array}{l}\text { Population density \& structure } \\
\text { of employment used. } \\
\text { Classified as urban if }>6000 \\
\text { inhabitants, or if }>2 / 3 \text { not } \\
\text { employed in agriculture. All } \\
\text { other settlements defined as } \\
\text { 'rural' }\end{array}$ & & $\begin{array}{l}\text { Higher in rural areas, although } \\
\text { for those } \geq 75 \text { years, urban rates } \\
\text { were higher until } 2000 \text {, but this } \\
\text { reversed by } 2005 \text {. }\end{array}$ & $\begin{array}{l}\text { Rural (men \& } \\
\text { women, except } \\
\text { among oldest } \\
\text { age groups by } \\
\text { 2005) }\end{array}$ & Age, sex & $\begin{array}{l}\text { Deteriorating social \& } \\
\text { economic situation may } \\
\text { explain increasing suicide } \\
\text { rates, with some rural- } \\
\text { specific explanations, } \\
\text { including increased social } \\
\text { isolation \& poor provision } \\
\text { of medical services }\end{array}$ \\
\hline $\begin{array}{l}\text { Kapusta et a }{ }^{212} \\
\text { (2010) } \\
\text { Austria }\end{array}$ & Not specified & $\begin{array}{l}\text { Statistics Austria for } \\
\text { mortality database }\end{array}$ & $\begin{array}{l}\text { Not } \\
\text { specified }\end{array}$ & $\begin{array}{l}\text { Continuous measure of } \\
\text { population density }\end{array}$ & $\begin{array}{l}\text { Population } \\
\text { density in } 2001\end{array}$ & Lower rates in urban areas & Rural & $\begin{array}{l}\text { Population density, } \\
\text { religion, } \\
\text { unemployment rate, } \\
\text { income }\end{array}$ & $\begin{array}{l}\text { Access to mental health } \\
\text { care was also related to } \\
\text { rural-urban differences, } \\
\text { with fewer facilities in } \\
\text { rural areas }\end{array}$ \\
\hline $\begin{array}{l}\text { Chang et a }\left.\right|^{218} \\
\text { (2011) } \\
\text { Taiwan }\end{array}$ & $\begin{array}{l}\text { Certified suicides, } \\
\text { undetermined } \\
\text { death, death by } \\
\text { pesticide poisoning } \\
\text { \& suffocation: ICD-9 } \\
\text { codes E950-E959, } \\
\text { E980-E989, E863, \& } \\
\text { E913 }\end{array}$ & 1999-2007 & $\begin{array}{l}\mathrm{N}=37,326 \\
\text { suicides, }\end{array}$ & $\begin{array}{l}\text { Deaths assigned to } 358 \\
\text { districts according to } \\
\text { registered address on death } \\
\text { certificate. }\end{array}$ & $\begin{array}{l}\text { Residence at } \\
\text { death }\end{array}$ & $\begin{array}{l}\text { Rates highest in rural, East } \\
\text { Taiwan. No evidence of above- } \\
\text { average rates in large cities. In } \\
\text { Taipei, rates increased toward } \\
\text { suburbs. Income, population } \\
\text { density \& lone parent households } \\
\text { associated with risk. Spatial } \\
\text { patterning strongest in young } \\
\text { people }\end{array}$ & Rural & & \\
\hline $\begin{array}{l}\text { Cheung et al }{ }^{202} \\
\text { (2012) } \\
\text { Australia }\end{array}$ & $\begin{array}{l}\text { ICD-10 codes X60- } \\
\text { X84 and/or with the } \\
\text { 'intent' column } \\
\text { registered as ' } 2 \text { ' } \\
\text { (intentional self- } \\
\text { harm). }\end{array}$ & $\begin{array}{l}\text { National Coroners } \\
\text { Information System } \\
\text { (NCIS) } \\
\text { (2004-2008) }\end{array}$ & & $\begin{array}{l}\text { Rural, Remote \& Metropolitan } \\
\text { classification (RRMA) \& index } \\
\text { of remoteness: (1) } \\
\text { metropolitan zone with } \\
\text { population } \geq 100,000 \text { (RRMA 1- } \\
\text { 2); (2) Rural zones (RRMA 3-5); } \\
\text { (3) remote zones (RRMA 6-7) }\end{array}$ & $\begin{array}{l}\text { Post areas (PAs) } \\
(n=2507) \\
\text { assessed in } \\
2006 .\end{array}$ & $\begin{array}{l}\text { Counties with low population } \\
\text { density had higher suicide risk } \\
\text { than heavily-populated coastal } \\
\text { cities. Rates higher for men in } \\
\text { rural \& remote areas. Spatial } \\
\text { clusters identified in N. \& W. } \\
\text { areas. No rural-urban gradient } \\
\text { for women }\end{array}$ & $\begin{array}{l}\text { Rural (men), } \\
\text { equivalent } \\
\text { (women) }\end{array}$ & $\begin{array}{l}\text { Age \& sex } \\
\text { standardized } \\
\text { analyses }\end{array}$ & \\
\hline $\begin{array}{l}\text { Park \& Lester } 222 \\
\text { (2012) } \\
\text { South Korea }\end{array}$ & Not specified & $\begin{array}{l}\text { Korean Statistics } \\
\text { Promotion Institute \& } \\
\text { census data } \\
\text { Aged } 15+\text { years } \\
\text { (2005) }\end{array}$ & $\begin{array}{l}\mathrm{N}=12,011 \\
\text { suicides } \\
\text { (pop. } \\
\mathrm{n}=38.1 \mathrm{~m} \\
\text { aged } \geq 15 \text { ) }\end{array}$ & $\begin{array}{l}\text { Korea's administrative } \\
\text { districts. All townships without } \\
\text { their own municipalities were } \\
\text { classified as rural }\end{array}$ & & Suicide rates higher in rural areas & Rural & $\begin{array}{l}\text { Age, gender, marital } \\
\text { status, month of } \\
\text { suicide. }\end{array}$ & $\begin{array}{l}\text { Authors noted a high rate } \\
\text { of pesticide } \& \text { chemical } \\
\text { use as method of suicide. }\end{array}$ \\
\hline $\begin{array}{l}\text { Patel et al }{ }^{219} \\
\text { (2012) } \\
\text { India }\end{array}$ & $\begin{array}{l}\text { ICD-10 codes X60- } \\
\text { X84 }\end{array}$ & $\begin{array}{l}\text { Registrar General of } \\
\text { India } \\
\text { Aged 15+ years } \\
(2001-2003)\end{array}$ & $\begin{array}{l}\mathrm{N}=2,684 \\
\text { suicide } \\
\text { deaths }\end{array}$ & $\begin{array}{l}6671 \text { small areas, randomly } \\
\text { selected }\end{array}$ & Not specified & $\begin{array}{l}\text { Age-standardised suicide rates } \\
\text { were about two times higher in } \\
\text { rural than urban areas. Rates } \\
\text { varied between states, generally } \\
\text { higher in south India }\end{array}$ & Rural & $\begin{array}{l}\text { Age, sex, region, } \\
\text { marital status, } \\
\text { occupation, alcohol } \\
\text { use, household fuel } \\
\text { type, education } \\
\end{array}$ & $\begin{array}{l}\text { Higher rate in rural India } \\
\text { may be linked to } \\
\text { availability of pesticides }\end{array}$ \\
\hline $\begin{array}{l}\text { Titelman et al224 } \\
(2013) \\
\text { Nordic } \\
\text { countries }\end{array}$ & $\begin{array}{l}\text { Suicide \& self- } \\
\text { inflicted injury } \\
\text { ICD-8 \& ICD-9 codes } \\
\text { E950-E959; ICD-10 } \\
\text { codes X60-X84, } \\
\text { Y87.0 }\end{array}$ & $\begin{array}{l}\text { Aged 15+ years } \\
(1980-2009)\end{array}$ & & $\begin{array}{l}\text { No official definition. Rates in } \\
\text { larger regions compared to } \\
\text { each other }\end{array}$ & & $\begin{array}{l}\text { Rural areas in Norway, Finland, \& } \\
\text { Sweden had highest suicide } \\
\text { rates, while capital cities had } \\
\text { lower rates than national } \\
\text { averages }\end{array}$ & Rural & & \\
\hline
\end{tabular}




\begin{tabular}{|c|c|c|c|c|c|c|c|c|c|}
\hline $\begin{array}{l}\text { Study ID \& } \\
\text { setting }\end{array}$ & $\begin{array}{l}\text { Diagnostic criteria } \\
\& \text { outcome }\end{array}$ & $\begin{array}{l}\text { Case finding, age } \\
\text { range, years }\end{array}$ & $\begin{array}{l}\text { Sample } \\
\text { size \& no. } \\
\text { of cases }\end{array}$ & $\begin{array}{l}\text { Definition of spatial unit } \\
\text { (rural/urban) }\end{array}$ & $\begin{array}{l}\text { Timing of } \\
\text { urban }\end{array}$ & Findings & Higher in & Confounders & Comments \\
\hline $\begin{array}{l}\text { Law, Snider \& } \\
\text { De Leo } 203 \\
\text { (2014) } \\
\text { Australia }\end{array}$ & $\begin{array}{l}\text { Cases of "possible } \\
\text { suicide" \& } \\
\text { "undetermined } \\
\text { causes" were not } \\
\text { included. }\end{array}$ & $\begin{array}{l}\text { Queensland Suicide } \\
\text { Register, aged 15+ } \\
\text { years } \\
(2004-8)\end{array}$ & $\begin{array}{l}2,803 \\
\text { suicides }\end{array}$ & $\begin{array}{l}\text { Dichotomous categorization of } \\
38 \text { rural-urban areas }\end{array}$ & & $\begin{array}{l}\text { Deprivation associated with age- } \\
\text { standardized suicide mortality, } \\
\text { particularly in men aged } 15-59 . \\
\text { Deprivation factors had stronger } \\
\text { association with suicide risk in } \\
\text { urban areas, with non-significant } \\
\text { or inverse effects in rural areas }\end{array}$ & $\begin{array}{l}\text { Deprivation } \\
\text { increased } \\
\text { suicide rates, } \\
\text { particularly in } \\
\text { urban areas }\end{array}$ & $\begin{array}{l}22 \text { socioeconomic } \\
\text { variables indexing } \\
\text { material \& social } \\
\text { conditions \& } \\
\text { relative } \\
\text { socioeconomic } \\
\text { disadvantage }\end{array}$ & $\begin{array}{l}\text { Area-based indices of } \\
\text { deprivation may produce } \\
\text { inaccurate assessments of } \\
\text { rural socioeconomic } \\
\text { status }\end{array}$ \\
\hline $\begin{array}{l}\text { Ngui et al } 223 \\
\text { (2014) } \\
\text { Canada }\end{array}$ & $\begin{array}{l}\text { ICD-10 codes X60- } \\
\text { X84, Y87. }\end{array}$ & $\begin{array}{l}\text { Register } \\
\text { Aged 15+ years } \\
(2004-7)\end{array}$ & $\mathrm{N}=2,951$ & $\begin{array}{l}406 \text { postcode areas known as } \\
\text { "Forward sortation areas" }\end{array}$ & $\begin{array}{l}\text { Measured using } \\
\text { postal code of } \\
\text { place of death }\end{array}$ & $\begin{array}{l}\text { Most likely clusters of suicide } \\
\text { found in remote rural areas, } \\
\text { lowest in metropolitan areas. } \\
\text { Clusters likely driven by male } \\
\text { rates; women more likely to die } \\
\text { by suicide in urban areas }\end{array}$ & $\begin{array}{l}\text { Rural (men), } \\
\text { urban (women) }\end{array}$ & Age \& sex & \\
\hline $\begin{array}{l}\text { Qi et a }{ }^{205} \\
(2014) \\
\text { Australia }\end{array}$ & $\begin{array}{l}\text { ICD 9: 950.0-959.9 \& } \\
\text { ICD 10: X60-X84 }\end{array}$ & $\begin{array}{l}\text { ABS } \\
\text { Ages } 15+\text { years } \\
(1986-2005)\end{array}$ & $\begin{array}{l}\mathrm{N}=45,293 \\
\text { suicide } \\
\text { deaths }\end{array}$ & Statistical Local Area & $\begin{array}{l}\text { Place of suicide } \\
\text { occurrence }\end{array}$ & Suicide rates higher in rural areas & Rural & & \\
\hline $\begin{array}{l}\text { Searles et al }{ }^{209} \\
\text { (2014) } \\
\text { USA } \\
\text { (16 states) }\end{array}$ & & $\begin{array}{l}\text { Deaths categorized as } \\
\text { suicide in National } \\
\text { Violent Death } \\
\text { Reporting System } \\
\text { (2006-2008) }\end{array}$ & & $\begin{array}{l}\text { Based on population density, } \\
\text { distance to metropolitan area } \\
\& \text { employment to create } \\
\text { urban, rural adjacent \& rural } \\
\text { nonadjacent areas }\end{array}$ & $\begin{array}{l}\text { County of } \\
\text { residence }\end{array}$ & $\begin{array}{l}\text { Demographic, socioeconomic \& } \\
\text { mental health risk factors } \\
\text { differed amongst rural \& urban } \\
\text { cases; in rural areas cases were } \\
\text { less likely to receive a psychiatric } \\
\text { diagnosis \& less likely to be in } \\
\text { treatment for mental health } \\
\text { problems. History of substance } \\
\text { abuse, job \& financial problems } \\
\text { were more prevalent among } \\
\text { urban dwellers }\end{array}$ & $\begin{array}{l}\text { Did not } \\
\text { compare rural- } \\
\text { urban } \\
\text { differences } \\
\text { directly }\end{array}$ & $\begin{array}{l}\text { Age, sex, Hispanic } \\
\text { ethnicity, marital } \\
\text { status, homeless- } \\
\text { ness, urban-rural } \\
\text { residence, } \\
\text { veteran status, } \\
\text { mental health } \\
\text { history }\end{array}$ & $\begin{array}{l}\text { Risk factors for suicide, } \\
\text { including substance abuse } \\
\& \text { availability of mental } \\
\text { health services differ by } \\
\text { urban-rural location }\end{array}$ \\
\hline $\begin{array}{l}\text { Fontanella et } \\
\mathrm{a}^{207} \\
(2015) \\
\text { USA }\end{array}$ & $\begin{array}{l}\text { ICD-9 (Clinical } \\
\text { Modification) codes } \\
\text { E950-E959 and ICD- } \\
10 \text { codes X60-X84, } \\
\text { Y87.0 \& U03 }\end{array}$ & $\begin{array}{l}\text { Aged } 10-24 \text { years } \\
(1996-2010)\end{array}$ & $\begin{array}{l}\mathrm{N}=66,595 \\
\text { suicide } \\
\text { deaths }\end{array}$ & $\begin{array}{l}2003 \text { Rural-Urban Continuum } \\
\text { Codes from US Department of } \\
\text { Agriculture, classifying } 3141 \\
\text { US counties into } 9 \text { groups } \\
\text { based on population size \& } \\
\text { adjacency to metropolitan } \\
\text { areas }\end{array}$ & & $\begin{array}{l}\text { Rural suicide rates nearly double } \\
\text { those in urban areas. Disparities } \\
\text { persisted after controlling for } \\
\text { confounders. Male rates declined } \\
\text { in most urban areas over time, } \\
\text { but remained stable in rural } \\
\text { areas. Female rates increased in } \\
\text { both rural \& urban areas }\end{array}$ & Rural & $\begin{array}{l}\text { Education, ethnicity, } \\
\text { unemployment, } \\
\text { poverty, female- } \\
\text { headed households, } \\
\text { unemployment, } \\
\text { divorce, population } \\
\text { density, health } \\
\text { utilization, income }\end{array}$ & \\
\hline
\end{tabular}


Most studies have showed a consistently increased risk for suicide in rural compared with urban areas. $^{201,207,208,211,218,220}$ However, some studies have suggested that this effect may differ between men and women, as well as by age (Table 5), although such inconsistencies may be partly attributable to variation methodological approaches or differences over time. Variation in findings may also reflect the different characteristics of urban and rural places included in different studies, and how the distribution of resources, including mental health care, varies by country.

Increased suicide risk was most consistently found for rural men, ${ }^{201,202,227}$ with some evidence of a null effect $^{202}$ or reversed trends for women. ${ }^{204,223}$ It is currently unclear as to whether urban-rural differences in suicide rates are changing over time, with studies reporting that this mortality gap is both growing ${ }^{207,210,211}$ and narrowing ${ }^{204,217,220}$; both are possible and may be context dependent, subject to a range of other social and economic determinants of health ${ }^{209}$ (see Section 4.2). Further, as suicide rates in most countries are elevated among men (in some regions the rate is four times higher among men than women), the lower number of events for women may mean that some studies were underpowered to detect urban-rural variations in female suicide rates. Lower suicide rates in women, overall, may also be attributable to the fact that women are more likely to receive an open verdict than suicide on their death certificate, ${ }^{228,229}$ highlighting the need for careful definition of the outcome measure used in an epidemiological enquiry into variation in suicide rates.

\subsection{Neighbourhoods}

In an attempt to move beyond basic rural-urban gradients in suicide mortality, several studies have used small area investigations to examine neighbourhood variation which may account for variation in suicide rates (Table 6), including social isolation and integration. ${ }^{230}$ As before, this research has primarily been conducted in High Income countries, including Denmark, ${ }^{231}$ Australia, ${ }^{232} \mathrm{New}$ Zealand, ${ }^{233}$ the UK, ${ }^{213,234-237}$ United States, ${ }^{208,238}$ Canada, $^{216}$ Belguim, ${ }^{230}$ Austria, ${ }^{212}$ Netherlands, ${ }^{193}$ Finland, ${ }^{239}$ Taiwan, ${ }^{218,241}$ Brazil, $^{242}$ Slovenia ${ }^{243}$ and Japan. ${ }^{244}$ Both social fragmentation, ${ }^{223,230,236,237,243}$ and deprivation $193,203,230,233,236,239$ have been associated with suicide mortality, as well as some evidence of a relationship with income inequality, ${ }^{239}$ low social capital (in particular social trust), ${ }^{193,208,240,244}$ and low population density. ${ }^{208,213,230,232}$ Nonetheless, these relationships have not been uniformly observed, with for example, Chang et al. ${ }^{218}$ finding that social fragmentation was not strongly or consistently associated with suicide rates in Taiwan. A limited number of studies have also investigated climatic factors, ${ }^{238,241}$ including temperature, precipitation, sunshine, altitude and atmospheric pressure, finding they only explained a small amount of variance in suicide mortality, and were generally outweighed by socioeconomic factors. 
Table 6: Summary of studies of suicide rates by area/neighbourhood (from 1999 onwards, chronologically ordered)

\begin{tabular}{|c|c|c|c|c|c|c|c|c|}
\hline $\begin{array}{l}\text { Study ID \& } \\
\text { setting }\end{array}$ & $\begin{array}{l}\text { Diagnostic criteria } \\
\text { \& outcome }\end{array}$ & $\begin{array}{l}\text { Case finding, age } \\
\text { range, years }\end{array}$ & $\begin{array}{l}\text { Definition of } \\
\text { neighbourhood }\end{array}$ & $\begin{array}{l}\text { Timing of } \\
\text { exposure }\end{array}$ & Area-level measures & $\begin{array}{l}\text { Individual-level } \\
\text { measures }\end{array}$ & Findings & Comments \\
\hline $\begin{array}{l}\text { Neeleman \& } \\
\text { Wessely }^{235} \\
(1999) \\
\text { UK }\end{array}$ & $\begin{array}{l}\text { Suicide verdict, suicide } \\
\text { note found, method } \\
\text { unambiguously } \\
\text { indicated suicide, } \\
\text { and/or suicidal intent } \\
\text { recorded }\end{array}$ & $\begin{array}{l}\text { Office for National } \\
\text { Statistics \& } \\
\text { coroner's reports. } \\
\mathrm{N}=329 \text { suicides in } \\
\text { South London } \\
\text { (population } \\
\text { 902,008), 1991-3 } \\
\end{array}$ & $\begin{array}{l}109 \text { electoral wards } \\
\text { in London boroughs } \\
\text { Lewisham, Lambeth, } \\
\text { Southwark \& } \\
\text { Greenwich (mean } \\
\text { pop. } \mathrm{N}=8274 \text { ) }\end{array}$ & $\begin{array}{l}\text { Postcodes linked } \\
\text { to electoral wards }\end{array}$ & $\begin{array}{l}\text { Small area ethnic densities \& } \\
\text { deprivation (Jarman index) }\end{array}$ & Age \& sex & $\begin{array}{l}\text { Minority suicide rates were higher in } \\
\text { areas where minority groups were } \\
\text { fewer. White suicide rates were higher } \\
\text { in areas where more ethnic minorities } \\
\text { live, independent of deprivation or age }\end{array}$ & $\begin{array}{l}\text { Supports ethnic } \\
\text { density hypothesis } \\
\text { for completed } \\
\text { suicide }\end{array}$ \\
\hline $\begin{array}{l}\text { Whitley et a }{ }^{237} \\
\text { (1999) } \\
\text { UK }\end{array}$ & $\begin{array}{l}\text { Deaths coded as } \\
\text { suicide or open } \\
\text { verdict: ICD-9 codes } \\
\text { E950-E959, E980-E989 }\end{array}$ & 1981-1992 & & $\begin{array}{l}633 \text { parliamentary } \\
\text { constituencies of } \\
\text { Great Britain }\end{array}$ & $\begin{array}{l}\text { Townsend deprivation score, } \\
\text { Congdon's anomie index, mean } \\
\text { abstention rates from general } \\
\text { elections in 1979, 1983, } 1987 \text { \& } \\
1992\end{array}$ & & $\begin{array}{l}\text { Higher suicide rates associated with } \\
\text { higher abstention, social fragmentation } \\
\& \text { deprivation. Greatest for social } \\
\text { fragmentation. Areas with greatest } \\
\text { increases in social fragmentation over } \\
\text { study period also had greatest increases } \\
\text { in suicide }\end{array}$ & $\begin{array}{l}\text { Ecological study } \\
\text { unable to separate } \\
\text { contextual from } \\
\text { compositional } \\
\text { effects }\end{array}$ \\
\hline $\begin{array}{l}\text { Martikainen, } \\
\text { Maki \& } \\
\text { Blomgren } 39 \\
\text { (2004) } \\
\text { Finland }\end{array}$ & $\begin{array}{l}\text { ICD-9 codes E950- } \\
\text { E959B, E959X \& ICD- } \\
10 \text { codes X60-X84, } \\
X 870\end{array}$ & $\begin{array}{l}\text { Statistics Finland } \\
\text { Ages 15-99 } \\
\text { (1991-2001) }\end{array}$ & $\begin{array}{l}\text { Functional regions } \\
(\mathrm{n}=85) \text { were used, } \\
\text { which are } \\
\text { neighbouring } \\
\text { municipalities } \\
\text { grouped according } \\
\text { to travel-to-work } \\
\text { areas \& patterns of } \\
\text { cooperation among } \\
\text { municipalities } \\
\end{array}$ & $\begin{array}{l}\text { Area } \\
\text { characteristics } \\
\text { measured in } \\
\text { 1990, 1992, } 1993\end{array}$ & $\begin{array}{l}\text { Socioeconomic structure \& } \\
\text { deprivation, income inequality, } \\
\text { social cohesion }\end{array}$ & $\begin{array}{l}\text { Age, sex, SES, } \\
\text { household income, } \\
\text { housing tenure, } \\
\text { economic activity, } \\
\text { marital status, } \\
\text { family type, } \\
\text { household size, } \\
\text { mother tongue }\end{array}$ & $\begin{array}{l}\text { Suicide mortality varied between } \\
\text { regions; larger for men than women. } \\
\text { High mortality observed in deprived } \\
\text { areas \& areas with low family cohesion } \\
\text { \& voter turnout. Relationships were } \\
\text { attenuated, but not fully accounted for } \\
\text { after adjustment for individual } \\
\text { characteristics. Area characteristics did } \\
\text { not mediate/modify effects of } \\
\text { individual SES on suicide }\end{array}$ & Multilevel study \\
\hline $\begin{array}{l}\text { Hempstead }{ }^{208} \\
\text { (2006) } \\
\text { USA }\end{array}$ & ICD-9: E950-E959 & $\begin{array}{l}\text { Death certificates, } \\
\text { medical examiner } \\
\text { data } \\
15 \text { or older } \\
(1999-2001)\end{array}$ & Municipality & $\begin{array}{l}\text { Municipality of } \\
\text { death (not } \\
\text { residence) used }\end{array}$ & $\begin{array}{l}\text { Population density, demographic } \\
\text { structure, income, } \\
\text { unemployment \& crime rates }\end{array}$ & & $\begin{array}{l}\text { Low population density \& high } \% \text { single } \\
\text { person households predicted suicide } \\
\text { rates. More common in areas with } \\
\text { declining population between } 1990- \\
2000 \& \text { where divorce rates were high }\end{array}$ & \\
\hline $\begin{array}{l}\text { Agerbo, Sterne } \\
\text { \& Gunnell }{ }^{231} \\
(2007) \\
\text { Denmark }\end{array}$ & $\begin{array}{l}\text { ICD-8 codes E950-959 } \\
\& \text { ICD-10 codes X60- } \\
\text { X84 }\end{array}$ & $\begin{array}{l}\text { Medical Register on } \\
\text { Vital Statistics } \\
\text { Ages 25-60 } \\
(1982-1997)\end{array}$ & $\begin{array}{l}\text { Municipalities in } \\
\text { Denmark ( } N=276)\end{array}$ & Year of suicide & $\begin{array}{l}\text { \% of people living alone, } \% \\
\text { employed individuals (based on } \\
\text { male employment), median gross } \\
\text { income (by male income) }\end{array}$ & $\begin{array}{l}\text { Marital status, gross } \\
\text { income, } \\
\text { employment }\end{array}$ & $\begin{array}{l}\text { When adjusted for individual measures, } \\
\text { area-level associations were weak. Little } \\
\text { evidence of cross-level interaction (that } \\
\text { individual risk varied based on area } \\
\text { characteristics) }\end{array}$ & $\begin{array}{l}\text { Area-level } \\
\text { associations } \\
\text { explained by } \\
\text { composition of high- } \\
\text { risk individuals in } \\
\text { some areas } \\
\end{array}$ \\
\hline $\begin{array}{l}\text { Stark et } a^{213} \\
(2007) \\
\text { Scotland }\end{array}$ & $\begin{array}{l}\text { ICD-9 codes E950- } \\
\text { E959. ICD-10 codes } \\
\text { X60-X84, E980-E989 \& } \\
Y 10-Y 34 \\
\end{array}$ & $\begin{array}{l}\text { General Register } \\
\text { Office for Scotland } \\
1981-1999\end{array}$ & $\begin{array}{l}\text { Postcode sector } \\
\text { (used as proxy for } \\
\text { rurality) }\end{array}$ & $\begin{array}{l}\text { Death allocated to } \\
\text { area of residency, } \\
\text { not area at death. }\end{array}$ & Deprivation \& population density & & $\begin{array}{l}\text { Deprivation was strongly associated } \\
\text { with suicide rates in Scotland for all } \\
\text { levels of population density for all ages }\end{array}$ & \\
\hline $\begin{array}{l}\text { O’Reilly et al }^{236} \\
(2008) \\
\text { Northern } \\
\text { Ireland } \\
\end{array}$ & $\begin{array}{l}\text { ICD-10 codes X60-X84, } \\
\text { Y10-Y34, Y87.0 }\end{array}$ & $\begin{array}{l}\text { Northern Ireland } \\
\text { Statistics \& } \\
\text { Research Agency } \\
\text { linked all those in }\end{array}$ & & $\begin{array}{l}\text { Census super- } \\
\text { output area level } \\
\text { (a standard } \\
\text { government } \\
\end{array}$ & $\begin{array}{l}\text { Material deprivation (\%receiving } \\
\text { social security benefits), } \\
\text { population density, social } \\
\text { fragmentation (\% in rented }\end{array}$ & $\begin{array}{l}\text { Marital status, } \\
\text { household size, SES, } \\
\text { economic activity, }\end{array}$ & $\begin{array}{l}\text { Higher suicide rates in more deprived \& } \\
\text { fragmented areas disappeared after } \\
\text { adjustment for individual \& household } \\
\text { factors. No relationship between }\end{array}$ & $\begin{array}{l}\text { Area-level } \\
\text { associations } \\
\text { explained by } \\
\text { composition of high- }\end{array}$ \\
\hline
\end{tabular}




\begin{tabular}{|c|c|c|c|c|c|c|c|c|}
\hline $\begin{array}{l}\text { Study ID \& } \\
\text { setting }\end{array}$ & $\begin{array}{l}\text { Diagnostic criteria } \\
\& \text { outcome }\end{array}$ & $\begin{array}{l}\text { Case finding, age } \\
\text { range, years }\end{array}$ & $\begin{array}{l}\text { Definition of } \\
\text { neighbourhood }\end{array}$ & $\begin{array}{l}\text { Timing of } \\
\text { exposure }\end{array}$ & Area-level measures & $\begin{array}{l}\text { Individual-level } \\
\text { measures }\end{array}$ & Findings & Comments \\
\hline & & $\begin{array}{l}2001 \text { census to } \\
\text { deaths in the } \\
\text { subsequent } 5 \text { years. } \\
\mathrm{n}=1,116,748 \text { ( } \mathrm{n}=566 \\
\text { suicides) } \\
\text { aged } 16-74\end{array}$ & & $\begin{array}{l}\text { administrative } \\
\text { area, with } \\
\text { average } \\
\text { population size } \\
1,894)\end{array}$ & $\begin{array}{l}\text { accommodation, unmarried, less } \\
\text { than } 65 \text { living alone, population } \\
\text { turnover in year preceding } \\
\text { census) }\end{array}$ & $\begin{array}{l}\text { self-reported health } \\
\text { status }\end{array}$ & $\begin{array}{l}\text { population density } \& \text { suicide. } \\
\text { Differences in rates of suicide between } \\
\text { areas due to population composition } \\
\text { than area-level factors. }\end{array}$ & $\begin{array}{l}\text { risk individuals in } \\
\text { some areas }\end{array}$ \\
\hline $\begin{array}{l}\text { Haws }^{238} \\
\text { (2009) } \\
\text { USA }\end{array}$ & Not specified & $\begin{array}{l}\text { Not specified } \\
(1990-1994)\end{array}$ & States & Not specified & $\begin{array}{l}\text { Elevation (i.e. altitude, of state } \\
\text { capital city) }\end{array}$ & $\begin{array}{l}\text { Age, race/ethnicity, } \\
\text { sex }\end{array}$ & $\begin{array}{l}\text { After adjustment, altitude of the state } \\
\text { capital city was significantly correlated } \\
\text { with suicide rates. }\end{array}$ & \\
\hline $\begin{array}{l}\text { Collings et al }{ }^{233} \\
\text { (2009) } \\
\text { New Zealand }\end{array}$ & $\begin{array}{l}\text { ICD-9 codes E950- } \\
\text { E959, } \\
\text { E980-E989 }\end{array}$ & $\begin{array}{l}2.8 \text { million } \\
\text { respondents in } 1996 \\
\text { census, followed up } \\
\text { for } 3 \text { years for } \\
\text { mortality ( } n=1101 \\
\text { suicide deaths), } \\
\text { Aged } 20-74 \text { years at } \\
\text { follow-up. } \\
\text { (1996-2000) }\end{array}$ & $\begin{array}{l}\text { There were } 1775 \\
\text { area units } \\
\text { (approximately } \\
2000 \text { people in each } \\
\text { area) with borders } \\
\text { based on locally } \\
\text { recognisable } \\
\text { communities. }\end{array}$ & & $\begin{array}{l}\text { Index of } \\
\text { Neighbourhood Social } \\
\text { Fragmentation, Congdon index of } \\
\text { fragmentation, neighbourhood } \\
\text { deprivation }\end{array}$ & $\begin{array}{l}\text { Age, sex, ethnicity, } \\
\text { educational } \\
\text { qualification, } \\
\text { marital status }\end{array}$ & $\begin{array}{l}\text { No linear association between } \\
\text { neighbourhood fragmentation \& } \\
\text { suicide. However, a U-shaped } \\
\text { association was suggested by Congdon } \\
\text { index, indicating that living in the most } \\
\text { or least fragmented decile of } \\
\text { neighbourhoods was associated with } \\
\text { increased suicide rates. Neighbourhood } \\
\text { deprivation also predicted suicide rates. } \\
\text { Authors concluded that neighbourhood } \\
\text { SES is a risk factor for suicide } \\
\text { independent of individual-level } \\
\text { socioeconomic position }\end{array}$ & \\
\hline $\begin{array}{l}\text { Kelly et al }{ }^{246} \\
\text { (2009) } \\
\text { Europe }\end{array}$ & & $\begin{array}{l}\text { National suicide } \\
\text { rates from World } \\
\text { Health Organization } \\
(2002-2004)\end{array}$ & $\begin{array}{l}\text { Comparing } 11 \\
\text { European nations }\end{array}$ & $\begin{array}{l}2003-4 \text { variables } \\
\text { measured in } \\
\text { European Social } \\
\text { Survey }\end{array}$ & $\begin{array}{l}\text { Social trust, aage, sex, marriage } \\
\text { rates, income \& reported sadness }\end{array}$ & $\mathrm{N} / \mathrm{A}$ & $\begin{array}{l}\text { National suicide rates inversely related } \\
\text { to social trust after controlling other } \\
\text { factors }\end{array}$ & Ecological study \\
\hline $\begin{array}{l}\text { Kapusta et a }\left.\right|^{243} \\
\text { (2010) } \\
\text { Austria }\end{array}$ & & $\begin{array}{l}\text { Statistics Austria for } \\
\text { mortality database } \\
(1991-2005)\end{array}$ & $\begin{array}{l}\text { Districts (90 in } \\
\text { Austria) }\end{array}$ & & $\begin{array}{l}\text { Population density, religion (\% } \\
\text { Roman Catholic), mean income, } \\
\text { unemployment rate, number of } \\
\text { general practitioners, } \\
\text { psychiatrists \& non-physician } \\
\text { psychotherapists }\end{array}$ & & $\begin{array}{l}\text { Neither density of general practitioners } \\
\text { or psychiatrists associated with suicide } \\
\text { rates, but weak association of } \\
\text { association with psychotherapist } \\
\text { density. }\end{array}$ & $\begin{array}{l}\text { Little variance in } \\
\text { density of GPs in } \\
\text { Austria may explain } \\
\text { lack of association }\end{array}$ \\
\hline $\begin{array}{l}\text { Tsai }{ }^{21} \\
(2010) \\
\text { Taiwan }\end{array}$ & & $\begin{array}{l}\text { Population based } \\
\text { mortality database } \\
\text { from the } \\
\text { Department of } \\
\text { Health in Taiwan. } \\
(1998-2006)\end{array}$ & & & $\begin{array}{l}\text { Population characteristics } \\
\text { (gender, age), socioeconomic } \\
\text { status (marriage, unemployment, } \\
\text { income) \& climatic factors } \\
\text { (temperature, atmospheric } \\
\text { pressure, precipitation, duration } \\
\text { of sunshine) }\end{array}$ & Not measured & $\begin{array}{l}\text { Suicide was negativaely correlated with } \\
\text { temperature \& positively correlated } \\
\text { with sunshine. Socioeconomic \& } \\
\text { climatic factors contributed } 52.7 \% \text { \& } \\
6.8 \% \text { respectively to variance in suicide } \\
\text { mortality }\end{array}$ & \\
\hline $\begin{array}{l}\text { Qi, Tong \& } \\
\mathrm{Hu}^{232} \\
(2010) \\
\text { Australia }\end{array}$ & & $\begin{array}{l}\text { Australian Bureau of } \\
\text { Statistics (ABS) } \\
1999-2003 \\
\mathrm{~N}=2445 \text { suicide } \\
\text { deaths } \\
\text { All ages }\end{array}$ & & $\begin{array}{l}\text { Statistical Local } \\
\text { Area (SLA, } n=452 \text { ) } \\
\text { \& Local } \\
\text { Governmental } \\
\text { Area (LGA). Urban } \\
\text { LGAs contained } \\
\text { 2+ SLAs \& rural/ } \\
\text { remote areas }\end{array}$ & Geographical variation & $\begin{array}{l}\text { Age, sex, year \& } \\
\text { month of suicide, } \\
\text { country of birth, } \\
\text { Statistical Local Area }\end{array}$ & $\begin{array}{l}\text { Significant suicide clusters were } \\
\text { discovered in NW \& N Australia. These } \\
\text { areas had very low population density. }\end{array}$ & $\begin{array}{l}\text { Higher rates may be } \\
\text { due to social } \\
\text { isolation, lack of } \\
\text { mental health } \\
\text { services. } \\
\text { Compositional } \\
\text { effects included } \\
\text { high \% minority } \\
\text { grousps \& low SES }\end{array}$ \\
\hline
\end{tabular}




\begin{tabular}{|c|c|c|c|c|c|c|c|c|}
\hline $\begin{array}{l}\text { Study ID \& } \\
\text { setting }\end{array}$ & $\begin{array}{l}\text { Diagnostic criteria } \\
\text { \& outcome }\end{array}$ & $\begin{array}{l}\text { Case finding, age } \\
\text { range, years }\end{array}$ & $\begin{array}{l}\text { Definition of } \\
\text { neighbourhood }\end{array}$ & $\begin{array}{l}\text { Timing of } \\
\text { exposure }\end{array}$ & Area-level measures & $\begin{array}{l}\text { Individual-level } \\
\text { measures }\end{array}$ & Findings & Comments \\
\hline $\begin{array}{l}\text { Chang et a }\left.\right|^{218} \\
\text { (2011) } \\
\text { Taiwan }\end{array}$ & $\begin{array}{l}\text { Certified suicides, } \\
\text { undetermined death, } \\
\text { accidental pesticide } \\
\text { poisoning, suffocation. } \\
\text { ICD-9 codes E950- } \\
\text { E959, E980-E989, } \\
\text { E863, E913. }\end{array}$ & (1999-2007) & $\begin{array}{l}358 \text { districts - } \\
\text { Districts are the } \\
\text { administrative unit } \\
\text { below the } \\
\text { county/city level. }\end{array}$ & $\begin{array}{l}\text { Residence } \\
\text { assigned based on } \\
\text { registered } \\
\text { address on death } \\
\text { certificate }\end{array}$ & $\begin{array}{l}\text { Single-person households, people } \\
\text { who moved to another district, } \\
\text { marital status, lone-parent } \\
\text { households, households not } \\
\text { owner-occupied, non-employed } \\
\text { adults, population aged 15-17 } \\
\text { not at school, adults with college } \\
\text { or higher education, median } \\
\text { household income, population } \\
\text { with limiting long term illnesses, } \\
\text { indigenous people, agricultural } \\
\text { workers, population density. }\end{array}$ & & $\begin{array}{l}\text { After controlling for other area } \\
\text { characteristics, increasing suicide rates } \\
\text { found in areas with high \% lone-parent } \\
\text { households, low household income \& } \\
\text { low population density. Indicators of } \\
\text { social fragmentation (i.e. population } \\
\text { mobility \& \% living alone / unmarried) } \\
\text { were not strongly associated with } \\
\text { suicide rates }\end{array}$ & \\
\hline $\begin{array}{l}\text { Hooghe \& } \\
\text { Vanhoutte }{ }^{230} \\
\text { (2011) } \\
\text { Belgium }\end{array}$ & & $\begin{array}{l}\text { Official death } \\
\text { certificates } \\
\text { (confirmed by a } \\
\text { medical doctor) } \\
1996-2005 \\
\mathrm{~N}=12,000 \text { registered } \\
\text { cases of suicide }\end{array}$ & & $\begin{array}{l}308 \text { communities } \\
\text { in Flanders region }\end{array}$ & $\begin{array}{l}\text { Social integration (religious } \\
\text { participation, rate of single } \\
\text { households, internal migration } \\
\text { rate, external migration rate, } \\
\text { presence of non-European } \\
\text { inhabitants), socioeconomic } \\
\text { deprivation (average income), } \\
\text { rural-urban divide (population } \\
\text { density - inhabitants } / \mathrm{km}^{2} \text { ), age \& } \\
\text { sex }\end{array}$ & & $\begin{array}{l}\text { Community characteristics were } \\
\text { significantly related to suicide rates. } \\
\text { Measures of social integration were } \\
\text { mixed: single person households \& } \\
\text { deprivation were associated with higher } \\
\text { suicide rates; religious participation was } \\
\text { unrelated; population density, } \\
\text { immigration \& presence of non- } \\
\text { European inhabitants with lower suicide } \\
\text { rates. Areas with older populations had } \\
\text { higher suicide risks than expected }\end{array}$ & $\begin{array}{l}\text { Ecological study } \\
\text { Communities have } \\
\text { an impact on } \\
\text { suicidal behaviours, } \\
\text { possibly via effects } \\
\text { of social isolation }\end{array}$ \\
\hline $\begin{array}{l}\text { Bando et } \mathrm{al}^{242} \\
\text { (2012) } \\
\text { Brazil }\end{array}$ & ICD-10 & $\begin{array}{l}\text { Brazilian \& São } \\
\text { Paulo State Death } \\
\text { Registry Databases } \\
\text { Ages } 15 \text { or older } \\
1996-2008 \\
\mathrm{n}=98904 \text { deaths } \\
\text { (Brazil), } 21066 \text { in } \\
\text { São Paulo State, } \\
5589 \text { in São Paulo } \\
\text { city }\end{array}$ & $\begin{array}{l}\text { Deaths assigned to } \\
\text { states ( } 27 \text { Brazilian } \\
\text { states \& } 558 \text { micro- } \\
\text { regions), } 645 \\
\text { counties of SP state } \\
\& 96 \text { districts of SP } \\
\text { city. }\end{array}$ & & Average income & Sex & $\begin{array}{l}\text { Higher suicide rates found in wealthier } \\
\text { areas of Brazil, São Paulo city \& poorer } \\
\text { areas of São Paulo state. May reflect } \\
\text { worldwide patterns, where direct } \\
\text { associations with income are found in } \\
\text { more equal areas, but inverse is found } \\
\text { in areas with more inequality. Regional } \\
\text { socioeconomic characteristics may } \\
\text { moderate association between SES \& } \\
\text { suicide risk }\end{array}$ & Ecological study \\
\hline $\begin{array}{l}\text { Congdon' }{ }^{234} \\
\text { (2012) } \\
\text { UK }\end{array}$ & & $\begin{array}{l}\text { Adult Psychiatric } \\
\text { Morbidity Survey }\end{array}$ & & $\begin{array}{l}\text { Government } \\
\text { office region } \\
\text { (REG) \& small } \\
\text { area deprivation } \\
\text { quintile (QIMD). }\end{array}$ & Age, ethnicity, social capital & $\begin{array}{l}\text { Household income, } \\
\text { education, marital } \\
\text { status employment, } \\
\text { owner occupied } \\
\text { housing, receipt of } \\
\text { income benefit, one } \\
\text { person household, } \\
\text { migrant in previous } \\
\text { year } \\
\end{array}$ & $\begin{array}{l}\text { Neighbourhood perceptions associated } \\
\text { with suicidal behaviours. However, area } \\
\text { deprivation did not have a distinct } \\
\text { significant influence, in contrast to a } \\
\text { number of ecological studies. } \\
\text { Deprivation may be partially mediated } \\
\text { by social capital }\end{array}$ & \\
\hline $\begin{array}{l}\text { Zhang \& } \\
\text { Wang } 248 \\
\text { (2012) } \\
\text { China }\end{array}$ & Not specified & $\begin{array}{l}\text { Part of a large } \\
\text { psychological } \\
\text { autopsy project } \\
\text { ages } 15-34 \mathrm{n}=392 \\
\text { suicide, } 416 \text { controls }\end{array}$ & & & $\begin{array}{l}\text { WHO Community Stress \& } \\
\text { Problems scale - social \& } \\
\text { structural stresses, community } \\
\text { behavioural problems }\end{array}$ & $\begin{array}{l}\text { Age, sex, education, } \\
\text { income, marital } \\
\text { status, physical } \\
\text { illness, mental } \\
\text { disorder \& status in } \\
\text { family. }\end{array}$ & $\begin{array}{l}\text { Neighbourhood stresses \& problems } \\
\text { increase suicide risk in rural China. } \\
\text { Health care, alcohol, job security, family } \\
\text { disputes \& transportation found to } \\
\text { have important roles in increasing } \\
\text { suicide risks }\end{array}$ & \\
\hline
\end{tabular}




\begin{tabular}{|c|c|c|c|c|c|c|c|c|}
\hline $\begin{array}{l}\text { Study ID \& } \\
\text { setting }\end{array}$ & $\begin{array}{l}\text { Diagnostic criteria } \\
\& \text { outcome }\end{array}$ & $\begin{array}{l}\text { Case finding, age } \\
\text { range, years }\end{array}$ & $\begin{array}{l}\text { Definition of } \\
\text { neighbourhood }\end{array}$ & $\begin{array}{l}\text { Timing of } \\
\text { exposure }\end{array}$ & Area-level measures & $\begin{array}{l}\text { Individual-level } \\
\text { measures }\end{array}$ & Findings & Comments \\
\hline $\begin{array}{l}\text { Jagodic et al } 243 \\
\text { (2013) } \\
\text { Slovenia }\end{array}$ & & $\begin{array}{l}\text { Institute of Public } \\
\text { Health of the } \\
\text { Republic of Slovenia } \\
\text { (mandatory registry } \\
\text { of all deaths) } \\
\text { (2000-2009) }\end{array}$ & $\begin{array}{l}\text { Population divided } \\
\text { into } 12 \text { statistical } \\
\text { regions } \\
\text { (administrative } \\
\text { entities) }\end{array}$ & 2000 & $\begin{array}{l}\text { GDP per capita, unemployment, } \\
\text { marriages rates, divorces rates, } \\
\text { mental health service availability } \\
\text { (psychiatrists per } 100,000, \\
\text { availability of psychological } \\
\text { services \& primary care doctors), } \\
\text { prevalence of mental disorders, } \\
\text { prescribed antiolytics \& } \\
\text { antidepressants, age \& sex } \\
\end{array}$ & & $\begin{array}{l}\text { Unemployment rate, marriage/divorce } \\
\text { ratio, psychiatrist availability \& quality } \\
\text { of depressive disorder treatment } \\
\text { predicted regional suicide rates }\end{array}$ & Ecological study \\
\hline $\begin{array}{l}\text { Kunst et al193 } \\
\text { (2013) } \\
\text { Netherlands }\end{array}$ & $\begin{array}{l}\text { ICD-9 codes E950- } \\
\text { E959 \& ICD-10 codes } \\
\text { X60-X84 }\end{array}$ & $\begin{array}{l}\text { Mortality record \& } \\
\text { population data } \\
\text { from Statistics } \\
\text { Netherlands (CBS) } \\
\mathrm{n}=6207 \text { suicide } \\
\text { deaths } \\
\mathrm{n}=117,569 \\
\text { individuals } \\
18+\text { years } \\
(1995-2000)\end{array}$ & $\begin{array}{l}\mathrm{N}=3507 \\
\text { neighbourhoods. } \\
\text { Place of residence } \\
\text { defined by } \\
\text { meaningful socio- } \\
\text { economic or } \\
\text { geographical } \\
\text { boundaries, } \\
\text { corresponding to } \\
\text { people's } \\
\text { perceptions of their } \\
\text { community. }\end{array}$ & $\begin{array}{l}\text { Place of residence } \\
\text { by postal code } \\
\text { data on January 1, } \\
1995\end{array}$ & $\begin{array}{l}\text { Area income, population density, } \\
\text { religious orientation, social } \\
\text { capital (WBO Housing Demand } \\
\text { Survey in 1998) \& complimentary } \\
\text { measure of social fragmentation } \\
\text { based on Congdon index }\end{array}$ & $\begin{array}{l}\text { Age sex, marital } \\
\text { status, country of } \\
\text { origin }\end{array}$ & $\begin{array}{l}\text { After controlling for individual factors, } \\
\text { suicide rates were } 60 \% \text { higher in areas } \\
\text { with lowest income compared with } \\
\text { highest income. Variations in suicide } \\
\text { rates according to population density \& } \\
\text { cultural/religious variables were smaller } \\
\& \text { non-linear. Suicide mortality rates } \\
\text { were higher in areas with low social } \\
\text { capital. Effect of social capital on suicide } \\
\text { mortality more pronounced for some } \\
\text { population subgroups (men, younger } \\
\text { people \& unmarried individuals) }\end{array}$ & $\begin{array}{l}\text { Cross-sectional } \\
\text { registry-based study }\end{array}$ \\
\hline $\begin{array}{l}\text { Okamoto et } \\
\text { al }{ }^{244} \\
(2013) \\
\text { Japan }\end{array}$ & & $\begin{array}{l}\text { Data from previous } \\
\text { survey, ages } 20+ \\
\text { (2006-2007 for } \\
\text { suicide \& } \\
\text { demographic } \\
\text { variables, } 2009 \text { for } \\
\text { social capital } \\
\text { measures) } \\
\end{array}$ & $\begin{array}{l}\text { Administrative } \\
\text { municipalities } \\
(n=20)\end{array}$ & & $\begin{array}{l}\text { Social capital (organizational } \\
\text { membership, social trust, } \\
\text { fairness, helpfulness, confidence } \\
\text { in organizations), sex, age, } \\
\text { population density, } \\
\text { unemployment, primary industry } \\
\text { workers, \% elderly, psychiatrist } \\
\text { availability }\end{array}$ & & $\begin{array}{l}\text { Suicide rates inversely related to social } \\
\text { trust for men, but not other indicators } \\
\text { of social capital }\end{array}$ & $\begin{array}{l}\text { Cross-sectional } \\
\text { Ecological study }\end{array}$ \\
\hline $\begin{array}{l}\text { Ngui et al223 } \\
\text { (2014) } \\
\text { Canada }\end{array}$ & $\begin{array}{l}\text { ICD-10 codes X60-X84, } \\
\& Y 87 .\end{array}$ & $\begin{array}{l}\text { Death Registry } \\
15+\text { years } \\
(2004-7)\end{array}$ & $\begin{array}{l}\text { Forward sortation } \\
\text { area (FSA) - first } 3 \\
\text { letters of the postal } \\
\text { code. }(n=406)\end{array}$ & $\begin{array}{l}\text { Postal code of the } \\
\text { place of death. }\end{array}$ & $\begin{array}{l}\text { \% renters, \% population without } \\
\text { a diploma, unemployment rate, } \\
\% \text { agricultural workers }\end{array}$ & Age \& sex & $\begin{array}{l}\text { Areas with highest } \% \text { single person } \\
\text { households more likely to contain a } \\
\text { suicide cluster. Less likely in areas with } \\
\text { high } \% 65+\text { years, single-parent families } \\
\& \% \text { without a diploma. For women, } \% \\
\text { single-parent families \& agricultural } \\
\text { workers increased likelihood of suicide } \\
\text { cluster, whereas \% with a university } \\
\text { education \& \% unemployed decreased } \\
\text { risk }\end{array}$ & $\begin{array}{l}\text { Not able to test for } \\
\text { individual } \\
\text { characteristics } \\
\text { Unknown how long } \\
\text { people had lived in } \\
\text { recorded location }\end{array}$ \\
\hline $\begin{array}{l}\text { Zammit et al }{ }^{247} \\
\text { (2014) } \\
\text { Sweden }\end{array}$ & $\begin{array}{l}\text { ICD-8 codes E950- } \\
\text { E959, E980-E989, ICD- } \\
9 \text {, codes E950-E959, } \\
\text { E980-E989, ICD-10 } \\
\text { codes X60-X84, Y10- } \\
\text { Y34 }\end{array}$ & $\begin{array}{l}204323 \text { individuals } \\
\text { born in Sweden in } \\
1972-1977 \text { up to age } \\
26-31 . \text { ( } N=314 \text { died } \\
\text { by suicide) }\end{array}$ & & & $\begin{array}{l}\text { School-level= average: foreign } \\
\text { born, social fragmentation, low } \\
\text { grade.Municipality = urbanicity, } \\
\text { population density, index of } \\
\text { social fragmentation (residential } \\
\text { mobility, voting, \% married/ } \\
\text { single households) }\end{array}$ & $\begin{array}{l}\text { Sex, country of } \\
\text { birth, history of } \\
\text { mental illness, } \\
\text { change of xbetween } \\
8 / 16 \text { years, parental } \\
\text { SES, education, } \\
\text { family income, } \\
\text { marital status, } \\
\text { school grade }\end{array}$ & $\begin{array}{l}\text { Little evidence that municipality-level } \\
\text { measures associated with suicide risk. } \\
\text { Several school-level measures were } \\
\text { associated with suicide risk.. Suicide risk } \\
\text { was higher for individuals who attended } \\
\text { schools with higher \% females. This } \\
\text { applied equally to men \& women. } \\
\text { Finally, social/cultural distance may } \\
\text { increase suicide risk }\end{array}$ & $\begin{array}{l}\text { Municipalities are } \\
\text { relatively large } \\
\text { geographical areas } \\
\text { which may not } \\
\text { capture small-area } \\
\text { level effects, which } \\
\text { may be captured at } \\
\text { school level }\end{array}$ \\
\hline
\end{tabular}


Despite investigating similar area-level measures, a number of methodological approaches were employed in neighbourhood-level enquiries of suicide risk (see Table 6), making direct comparisons challenging. For example, the spatial scale at which suicide rates were compared varied from locally recognizable communities to postcode areas, larger governmental administrative areas or political constituencies. In a systematic review of this literature, Rehkopf \& Buka ${ }^{245}$ found that studies conducted at smaller community levels were more likely to find lower suicide rates in higher socioeconomic areas than studies which used larger areas of aggregation. ${ }^{245}$ The authors recommend more attention to the size of region and measurement strategies in order to provide a clearer picture of how suicide rates vary by region.

Many studies were ecological - meaning that they only studied variance in rates between neighbourhoods, regionals or countries - and did not control for potentially relevant individual characteristics. ${ }^{223,237,241,244}$ This approach, while useful for hypothesis generation and further enquiry, makes it impossible to determine whether variation in suicide rates were due to compositional or contextual effects. ${ }^{236}$ To partially mitigate the risk of ecological fallacy, several multi-level studies (comibing both individual- and area-level risks) have been conducted. For example, following adjustment for a range of individual measures, Congdon et al. ${ }^{234}$ found that area deprivation had no distinct influence on suicide rates, in contrast to other studies. ${ }^{27,236,239}$ Nonetheless, simple control for individual factors also risks ignoring the complexity of how places make people, and how certain high risk individuals may be at more or less risk following exposure to further environmental factors (socalled cross-level interactions). ${ }^{249}$

Several studies have investigated such interactions; Neeleman \& Wessley, ${ }^{235}$ for example, have shown that suicide rates in different ethnic groups, including the white majority, were higher in areas with a smaller population of one's own ethnicity (i.e. an ethnic density effect), as consistently shown for schizophrenia (Section 2). Similarly, Kunst et al. ${ }^{193}$ demonstrated that the effect of social capital on suicide mortality was more pronounced for certain population groups, including young people, unmarried individuals, and men. Finally, a systematic review conducted by Crawford, Kuforiji, Ghosh, ${ }^{250}$ synthesizing data from 54 studies, found that established risk factors including unemployment, living alone, and ethnic minority status had less on suicide risk for individuals living in areas where these factors were more common. ${ }^{250}$

\subsection{Variation in risk by suicide methods}

There is strong evidence that the rural-urban gradient (higher rates in rural areas) for suicide mortality is strongly influenced by choice of method. Much of this literature points to the impact of accessibility 
when it comes to highly lethal means, including firearms, pesticides, and fertilizers, although this also appears to vary by setting. In countries including the United States, Canada, UK and Australia, there is consistent evidence showing that use of firearms for suicide is strongly spatially patterned, being more prevalent in rural and remote areas. ${ }^{205,207,209,211,223}$ Singh \& Siahpush ${ }^{210}$ have noted that firearms accounted for $75 \%$ of all rural suicides, but only half of such incidents in urban areas, and accessibility to firearms has been cited as a major contributory factor for rural-urban differences in several studies. ${ }^{207,210,223,251,252}$ Further, the changing availability of firearms may account for some time trends in suicide rates. Fontanella et al., ${ }^{207}$ for example, have noted that firearm ownership has decreased in urban areas, but remains stable in rural areas, potentially widening the disparity in both the accessibility of method and suicide rates between rural and urban communities. In urban areas, methods including jumping, poisoning and hanging are more common. ${ }^{223}$ Pesticide poisoning are more common in some rural areas, including in Taiwan ${ }^{218}$ and South Korea, ${ }^{222}$ with some evidence that hangings showed least geographic differences. ${ }^{218}$

These distinct geographic patterns of suicide methods appears to be driven by the ready availability of method, ${ }^{210}$ although may also be shaped by cultural norms, localised patters (i.e. imitation, see ${ }^{214}$ ) and social expectations. Levin ${ }^{214}$ also note that socioeconomic means may determine accessibility to certain more expensive methods, including the use of firearms or explosives. Changing attitudes towards firearms, increased regulations on storage and reduced access to firearms has been hown to reduce suicide rates. ${ }^{206,253}$ Large $\&$ Nielssen ${ }^{255}$ have used meta-analysis data to demonstrate that the decline in suicide in Australia coincided with a reduction in the availability of lethal means.

\subsection{Main hypotheses explaining the spatial heterogeneity in suicide mortality}

In addition to accessibility to methods and sociocultural influences, several other hypotheses have been proposed to explain the spatial patterning of suicide mortality, broadly organized into compositional, contextual, and cross-level explanations. We discuss each, in turn, below.

\subsubsection{Compositional hypotheses}

Compositional explanations posit that the individual characteristics of people within certain locales, including the social drift of high-risk individuals into certain areas, ${ }^{231}$ account for the rural-urban and spatial differences in suicide (and other) rates. Low income and education, unemployment and social isolation are all strongly related to suicide risk, ${ }^{27,236}$ and may be more prevalent in some communities as a result of both structural and cultural influences maintained over successive generations. In many rural areas, these compositional effects may be compounded by the "out-migration" of young, 
educated individuals, which generates greater psychological distress or a sense of entrapment in those left behind. ${ }^{251,256}$ It has been suggested that the subsequently increased levels of psychological distress may drive regional differences in suicide rates. However, there is no consistent evidence that differences in rates of psychiatric morbidity exist between areas with high and low suicide rates. ${ }^{215,251}$ If compositional effects account for the majority of spatial variance in suicide risk, public mental health strategies to ameloriate this burden can focus on both indicated and selective prevention interventions which target high risk individuals or subgroups of the population.

\subsubsection{Contextual hypotheses}

Contextual effects refer to direct effects that characteristics of places have on suicide risk, which go beyond the totality of compositional effects. These contextual effects may operate either through increased likelihood of suicidal behaviour, or through low levels of social support. ${ }^{231}$ Contextual explanations also include how the organization, accessibility, and availability of mental health care vary between different areas. The evidence for contextual effects for suicide (Table 6) generally indicates that areas characterized by greater social fragmentation, isolation and disintegration have higher mortality rates. This may reflect "differential changes over time in key social integration indicators," ${ }^{210}$ consistent with Durkheim's theory that "anomie" - low social integration - drives high suicide rates. Low levels of social integration may partly explain increased suicide rates in rural areas, $^{207,252}$ which may be confounded by changing demographic profiles in many rural and remote communities and deteriorating economic conditions. ${ }^{215,251}$ It has been suggested, for example, that rurality per se, may be less important than the differential effects of global economic trends on local regions, with certain rural communities particularly affected by downturns in economic activity. Further nuanced investigation of such intricate spatial variation of suicide is warranted. ${ }^{251}$

Suicide rates may also be influenced by the availability and accessibility of mental health care services and other public amenities in a given area. ${ }^{207,215,251,252}$ This may be compounded by issues of mental health literacy, less service utilization, concerns about stigma and discrimination, and lower willingness to seek help in some communities. Such barriers-to-care are often more common in rural communities, possibly due to cultural attitudes and shared norms. ${ }^{210,215,251,257}$ Cultural factors and stigma can also present barriers to treatment, including the possible lack of anonymity in more rural, smaller communities. ${ }^{207,252}$ In particular, community attitudes towards mental illness and help-seeking may contribute to elevated suicide rates, particularly amongst rural men. ${ }^{251}$ Other authors have noted that dominant masculine hegemony, which may be more common in some rural communities, tends 
to favour gendered expectations of stoicism and self-reliance, which may present a substantial barrier to help-seeking in the entire community. 251,256

\subsubsection{Cross-level hypotheses}

Cross-level effects focus on how characteristics of geographic areas may have differential effects on individuals based on their particular characteristics. If prominent, these effects would make the debate about compositional versus contextual effects overly reductionist. Since few individual (i.e. compositional) risk factors are truly exogenous to the social environment, simple adjustment for these factors in the search for contextual mechanisms in suicide risk risks ignoring how the effects of place affect people's social and economic opportunities, including access to good education and highincome jobs. Much of the research reviewed above may thus have overlooked, or have been underpowered to detect, important cross-level interactions which may be vital for the development of putative prevention strategies in different contexts. Theoretical support for cross-level interactions can be traced back to Durkheim's proposal that greater dissonance between an individual and his/her social environment the greater their risk of suicide. ${ }^{231}$ Likewise, Crawford and colleagues ${ }^{250}$ argued that the impact of unemployment on suicide risk may be exacerbated if unemployed individuals lived in area of high employment, although universal support for this has not been found. ${ }^{239}$ Combining the theoretical rational for cross-level interactions with empirical evidence is urgently warranted so we understand how "people make places and people make people," 249 and permit appropriate public mental health responses in different populations, subgroups and settings.

\section{Conclusion}

We have reviewed the literature on the association between urban living and three major sets of mental health outcomes, namely psychotic disorders, common mental disorders and suicide. Our comprehensive review of the current evidence, its strengths and limitations and possible hypotheses to explain any variation should serve as a useful reference point for those working in epidemiology, public mental health and mental health care and provision. But what do these findings say in regard to possible preventive strategies to reduce the global burden of mental disorders? What conclusions can we draw at this stage to promote the design and maintenance of healthy environments which promote positive mental health?

The reader will probably concur with our view that no universal answer exists to these questions. Common mental disorders show no consistent direction of association with urban or rural living, which in part might be due to heterogeneous study designs, difficulties with case detection and other forms 
of biases inherent to studying prevalent conditions for which people in the community may rarely seek help. Psychotic disorders and suicide showed stronger, more consistent associations with the environment, but in opposite directions; psychotic disorders being more common in urban populations, suicide generally being elevated in more rural communities. The extent to which these patterns were causally determined, that is due to the exposure rather than attributable to reverse causation, was considered, and for both outcomes there is reasonable evidence to implicate social and environmental determinants in the aetiology of these mental health outcomes. These may occur at a variety of levels, including as a result of individual attributes, such as poverty, unemployment and social class, as well as at household and neighbourhood levels.

For both psychotic disorders and suicide further research is required to investigate the extent to which social drift (of those with worse mental health into more deprived rural or urban communities) or upward social mobility (of those with better mental health away from such communities) may help to reveal whether patterns at the environmental level are purely compositional or at least partly contextual. Efforts to ameliorate exposure to advserse psychosocial adversities in the environment, including deprivation and social isolation may help reduce the occurrence of both schizophrenia and suicide, albeit that these efforts will need to be directed at different communities. For suicide the strong rural gradient associated with risk may be due in part to the availability of means, and more direct preventive strategies including tighter controls on firearms and pesticides may be worthwhile. For now, for all mental health outcomes, studies which can elucidate the multiple potential causal levels which drive increased risk of disorder are warranted, particularly those with a longitudinal element to their design which can tease out any sensitive windows to environmental factors over the life course. 


\section{Bibliography}

1. Weich, S. Absence of spatial variation in rates of the common mental disorders. J. Epidemiol. Community Health 59, 254-7 (2005).

2. Menezes, P. R. Commentary: epidemiological mental health research: contribution from lowand middle-income countries is essential. Int. J. Epidemiol. 43, 301-3 (2014).

3. Saha, S., Chant, D., Welham, J. \& McGrath, J. A systematic review of the prevalence of schizophrenia. PLoS Med. 2, e141 (2005).

4. McGrath, J. et al. A systematic review of the incidence of schizophrenia: the distribution of rates and the influence of sex, urbanicity, migrant status and methodology. BMC Med. 2, 13 (2004).

5. Kirkbride, J. B. et al. Heterogeneity in incidence rates of schizophrenia and other psychotic syndromes: findings from the 3-center AeSOP study. Arch. Gen. Psychiatry 63, 250-8 (2006).

6. Kirkbride, J. B. et al. Systematic Review of the Incidence and Prevalence of Schizophrenia and Other Psychoses in England. (2012).

7. Bresnahan, M. et al. Race and risk of schizophrenia in a US birth cohort: another example of health disparity? Int. J. Epidemiol. 36, 751-758 (2007).

8. Schofield, P., Ashworth, M. \& Jones, R. Ethnic isolation and psychosis: re-examining the ethnic density effect. Psychol. Med. 41, 1263-9 (2011).

9. Boydell, J. et al. Incidence of schizophrenia in ethnic minorities in London: ecological study into interactions with environment. BMJ 323, 1336-1336 (2001).

10. Veling, W. et al. Incidence of schizophrenia among ethnic minorities in the Netherlands: a fouryear first-contact study. Schizophr. Res. 86, 189-93 (2006).

11. Faris, R. E. L. \& Dunham, H. W. Mental Disorders in urban areas. (Chicago University Press, 1939).

12. Saha, S., Chant, D. C., Welham, J. L. \& McGrath, J. J. The incidence and prevalence of schizophrenia varies with latitude. Acta Psychiatr. Scand. 114, 36-39 (2006).

13. March, D. et al. Psychosis and place. Epidemiol. Rev. 30, 84-100 (2008).

14. Heinz, A., Deserno, L. \& Reininghaus, U. Urbanicity, social adversity and psychosis. World Psychiatry 12, 187-97 (2013).

15. Hare, E. H. Family Setting and the Urban Distribution of Schizophrenia. Br. J. Psychiatry 102, 753-760 (1956).

16. Löffler, W. \& Häfner, H. Ecological pattern of first admitted schizophrenics in two German cities over 25 years. Soc. Sci. Med. 49, 93-108 (1999).

17. Giggs, J. A. \& Cooper, J. E. Ecological structure and the distribution of schizophrenia and affective psychoses in Nottingham. Br. J. Psychiatry 151, 627-633 (1987).

18. Lewis, G., David, A., Andréasson, S. \& Allebeck, P. Schizophrenia and city life. Lancet (London, England) 340, 137-40 (1992).

19. Thornicroft, G., Bisoffi, G., De Salvia, D. \& Tansella, M. Urban-rural differences in the associations between social deprivation and psychiatric service utilization in schizophrenia and all diagnoses: a case-register study in Northern Italy. Psychol. Med. 23, 487-96 (1993).

20. Takei, N., Sham, P. C., O'Callaghan, E., Glover, G. \& Murray, R. M. Schizophrenia: increased risk associated with winter and city birth--a case-control study in 12 regions within England and Wales. J. Epidemiol. Community Health 49, 106-7 (1995).

21. Marcelis, M., Takei, N. \& van Os, J. Urbanization and risk for schizophrenia: does the effect operate before or around the time of illness onset? Psychol. Med. 29, 1197-203 (1999).

22. Marcelis, M., Navarro-Mateu, F., Murray, R., Selten, J. P. \& Van Os, J. Urbanization and psychosis: a study of 1942-1978 birth cohorts in The Netherlands. Psychol. Med. 28, 871-9 (1998).

23. Mortensen, P. B. et al. Effects of family history and place and season of birth on the risk of schizophrenia. N. Engl. J. Med. 340, 603-8 (1999).

24. Schelin, E. M., Munk-Jørgensen, P., Olesen, A. V \& Gerlach, J. Regional differences in 
schizophrenia incidence in Denmark. Acta Psychiatr. Scand. 101, 293-9 (2000).

25. Eaton, W. W., Mortensen, P. B. \& Frydenberg, M. Obstetric factors, urbanization and psychosis. Schizophr. Res. 43, 117-23 (2000).

26. Suvisaari, J. M., Haukka, J. K., Tanskanen, A. J. \& Lönnqvist, J. K. Decreasing seasonal variation of births in schizophrenia. Psychol. Med. 30, 315-24 (2000).

27. Agerbo, E., Torrey, E. F. \& Mortensen, P. B. Household crowding in early adulthood and schizophrenia are unrelated in Denmark: a nested case-control study. Schizophr. Res. 47, 2436 (2001).

28. Allardyce, J. Comparison of the incidence of schizophrenia in rural Dumfries and Galloway and urban Camberwell. Br. J. Psychiatry 179, 335-339 (2001).

29. Haukka, J., Suvisaari, J., Varilo, T. \& Lönnqvist, J. Regional variation in the incidence of schizophrenia in Finland: a study of birth cohorts born from 1950 to 1969. Psychol. Med. 31, 1045-53 (2001).

30. Pedersen, C. B. \& Mortensen, P. B. Family history, place and season of birth as risk factors for schizophrenia in Denmark: a replication and reanalysis. Br. J. Psychiatry 179, 46-52 (2001).

31. Pedersen, C. B. \& Mortensen, P. B. Evidence of a dose-response relationship between urbanicity during upbringing and schizophrenia risk. Arch. Gen. Psychiatry 58, 1039-46 (2001).

32. van Os, J., Hanssen, M., Bijl, R. V. \& Vollebergh, W. Prevalence of Psychotic Disorder and Community Level of Psychotic Symptoms. Arch. Gen. Psychiatry 58, 663 (2001).

33. Harrison, G. et al. Association between psychotic disorder and urban place of birth is not mediated by obstetric complications or childhood socio-economic position: a cohort study. Psychol. Med. 33, 723-31 (2003).

34. van Os, J., Hanssen, M., Bak, M., Bijl, R. V \& Vollebergh, W. Do urbanicity and familial liability coparticipate in causing psychosis? Am. J. Psychiatry 160, 477-82 (2003).

35. Sundquist, K., Frank, G. \& Sundquist, J. Urbanisation and incidence of psychosis and depression: follow-up study of 4.4 million women and men in Sweden. Br. J. Psychiatry 184, 293-8 (2004).

36. Allardyce, J. et al. Social fragmentation, deprivation and urbanicity: relation to first-admission rates for psychoses. Br. J. Psychiatry 187, 401-6 (2005).

37. Pedersen, C. B. \& Mortensen, P. B. Are the cause(s) responsible for urban-rural differences in schizophrenia risk rooted in families or in individuals? Am. J. Epidemiol. 163, 971-8 (2006).

38. Pedersen, C. B. \& Mortensen, P. B. Urbanization and traffic related exposures as risk factors for schizophrenia. BMC Psychiatry 6, 2 (2006).

39. Pedersen, C. B. No evidence of time trends in the urban-rural differences in schizophrenia risk among five million people born in Denmark from 1910 to 1986. Psychol. Med. 36, 211-9 (2006).

40. Laursen, T. M., Munk-Olsen, T., Nordentoft, M. \& Bo Mortensen, P. A comparison of selected risk factors for unipolar depressive disorder, bipolar affective disorder, schizoaffective disorder, and schizophrenia from a danish population-based cohort. J. Clin. Psychiatry 68, 1673-81 (2007).

41. Kelly, B. D. et al. Schizophrenia and the city: A review of literature and prospective study of psychosis and urbanicity in Ireland. Schizophr. Res. 116, 75-89 (2010).

42. Sørensen, H. J. et al. Population impact of familial and environmental risk factors for schizophrenia: a nationwide study. Schizophr. Res. 153, 214-9 (2014).

43. Szöke, A. et al. Rural-urban variation in incidence of psychosis in France: a prospective epidemiologic study in two contrasted catchment areas. BMC Psychiatry 14, 78 (2014).

44. Vassos, E., Agerbo, E., Mors, O. \& Pedersen, C. B. Urban-rural differences in incidence rates of psychiatric disorders in Denmark. Br. J. Psychiatry bjp.bp.114.161091- (2015). doi:10.1192/bjp.bp.114.161091

45. Moreno-Küstner, B. et al. Prevalence of schizophrenia and related disorders in Malaga (Spain): results using multiple clinical databases. Epidemiol. Psychiatr. Sci. 1-11 (2014).

46. Byrne, M., Agerbo, E., Eaton, W. W. \& Mortensen, P. B. Parental socio-economic status and risk of first admission with schizophrenia- a Danish national register based study. Soc. Psychiatry 
Psychiatr. Epidemiol. 39, 87-96 (2004).

47. Weiser, M. et al. Social and cognitive functioning, urbanicity and risk for schizophrenia. Br. J. Psychiatry 191, 320-4 (2007).

48. Xiang, Y.-T. et al. Prevalence and socio-demographic correlates of schizophrenia in Beijing, China. Schizophr. Res. 102, 270-7 (2008).

49. Ganguli, H. C. Epidemiological findings on prevalence of mental disorders in India. Indian J. Psychiatry 42, 14-20 (2000).

50. Vicente, B. et al. Regional differences in psychiatric disorders in Chile. Soc. Psychiatry Psychiatr. Epidemiol. 41, 935-942 (2006).

51. Wei, G. et al. The first epidemiological study of mental disorders of Tibetans. World Cult. Psychiatr. Res. Rev. 1-3 (2008).

52. Lundberg, P., Cantor-Graae, E., Rukundo, G., Ashaba, S. \& Ostergren, P.-O. Urbanicity of place of birth and symptoms of psychosis, depression and anxiety in Uganda. Br. J. Psychiatry 195, 156-62 (2009).

53. Phillips, M. R. et al. Prevalence, treatment, and associated disability of mental disorders in four provinces in China during 2001-05: an epidemiological survey. Lancet (London, England) 373, 2041-53 (2009).

54. Song, S., Wang, W. \& Hu, P. Famine, death, and madness: schizophrenia in early adulthood after prenatal exposure to the Chinese Great Leap Forward Famine. Soc Sci Med 68, 1315-1321 (2009).

55. Chan, K. Y. et al. Prevalence of schizophrenia in China between 1990 and 2010. J. Glob. Health 5, 010410 (2015).

56. Long, J. et al. The prevalence of schizophrenia in mainland China: evidence from epidemiological surveys. Acta Psychiatr. Scand. 130, 244-56 (2014).

57. Vassos, E., Pedersen, C. B., Murray, R. M., Collier, D. A. \& Lewis, C. M. Meta-analysis of the association of urbanicity with schizophrenia. Schizophr. Bull. 38, 1118-23 (2012).

58. Chan, K. Y. et al. Urbanization and the prevalence of schizophrenia in China between 1990 and 2010. World Psychiatry 14, 251-2 (2015).

59. Dauncey, K., Giggs, J., Baker, K. \& Harrison, G. Schizophrenia in Nottingham: lifelong residential mobility of a cohort. Br. J. Psychiatry 163, 613-619 (1993).

60. Croudace, T. J., Kayne, R., Jones, P. B. \& Harrison, G. L. Non-linear relationship between an index of social deprivation, psychiatric admission prevalence and the incidence of psychosis. Psychol. Med. 30, 177-85 (2000).

61. Van Os, J. Neighbourhood variation in incidence of schizophrenia: Evidence for personenvironment interaction. Br. J. Psychiatry 176, 243-248 (2000).

62. Boydell, J., van Os, J., McKenzie, K. \& Murray, R. M. The association of inequality with the incidence of schizophrenia--an ecological study. Soc. Psychiatry Psychiatr. Epidemiol. 39, 5979 (2004).

63. Drukker, M., Krabbendam, L., Driessen, G. \& van Os, J. Social disadvantage and schizophrenia. Soc. Psychiatry Psychiatr. Epidemiol. 41, 595-604 (2006).

64. Lofors, J. \& Sundquist, K. Low-linking social capital as a predictor of mental disorders: a cohort study of 4.5 million Swedes. Soc. Sci. Med. 64, 21-34 (2007).

65. Kirkbride, J. B. et al. Neighbourhood variation in the incidence of psychotic disorders in Southeast London. Soc. Psychiatry Psychiatr. Epidemiol. 42, 438-445 (2007).

66. Kirkbride, J. B. et al. Neighbourhood-level effects on psychoses: re-examining the role of context. Psychol. Med. 37, 1413-25 (2007).

67. Kirkbride, J. B. et al. Testing the association between the incidence of schizophrenia and social capital in an urban area. Psychol. Med. 38, 1083-94 (2008).

68. Veling, W. et al. Ethnic density of neighborhoods and incidence of psychotic disorders among immigrants. Am. J. Psychiatry 165, 66-73 (2008).

69. Zammit, S. et al. Individuals, schools, and neighborhood: a multilevel longitudinal study of 
variation in incidence of psychotic disorders. Arch. Gen. Psychiatry 67, 914-22 (2010).

70. Bhavsar, V., Boydell, J., Murray, R. \& Power, P. Identifying aspects of neighbourhood deprivation associated with increased incidence of schizophrenia. Schizophr. Res. 156, 115-21 (2014).

71. Kirkbride, J. B., Jones, P. B., Ullrich, S. \& Coid, J. W. Social deprivation, inequality, and the neighborhood-level incidence of psychotic syndromes in East London. Schizophr. Bull. 40, 16980 (2014).

72. Lasalvia, A. et al. First-contact incidence of psychosis in north-eastern Italy: influence of age, gender, immigration and socioeconomic deprivation. Br. J. Psychiatry 205, 127-34 (2014).

73. Omer, S. et al. Neighbourhood-level socio-environmental factors and incidence of first episode psychosis by place at onset in rural Ireland: the Cavan-Monaghan First Episode Psychosis Study [CAMFEPS]. Schizophr. Res. 152, 152-7 (2014).

74. B. O'Donoghue et al. Neighbourhood characteristics and the incidence of first-episode psychosis and duration of untreated psychosis. Psychol. Med. 1-12 doi:10.1017/S003329171500286X

75. Veling, W., Susser, E., Selten, J.-P. \& Hoek, H. W. Social disorganization of neighborhoods and incidence of psychotic disorders: a 7-year first-contact incidence study. Psychol. Med. 45, 1789-1798 (2015).

76. Sariaslan, A. et al. Does population density and neighborhood deprivation predict schizophrenia? A nationwide Swedish family-based study of 2.4 million individuals. Schizophr. Bull. 41, 494-502 (2015).

77. Werner, S., Malaspina, D. \& Rabinowitz, J. Socioeconomic Status at Birth Is Associated With Risk of Schizophrenia: Population-Based Multilevel Study. Schizophr. Bull. 33, 1373-1378 (2006).

78. Burns, J. K. \& Esterhuizen, T. Poverty, inequality and the treated incidence of first-episode psychosis: an ecological study from South Africa. Soc. Psychiatry Psychiatr. Epidemiol. 43, 3315 (2008).

79. Silver, E., Mulvey, E. P. \& Swanson, J. W. Neighborhood structural characteristics and mental disorder: Faris and Dunham revisited. Soc. Sci. Med. 55, 1457-70 (2002).

80. Kirkbride, J. B. et al. Addendum. Psychol. Med. 41, 2462 (2011).

81. Kawachi, I. Commentary: social capital and health: making the connections one step at a time. Int. J. Epidemiol. 35, 989-93 (2006).

82. Mckenzie, K. Urbanization, Social Capital and Mental Health. Glob. Soc. Policy 8, 359-377 (2008).

83. De Silva, M. J., McKenzie, K., Harpham, T. \& Huttly, S. R. A. Social capital and mental illness: a systematic review. J. Epidemiol. Community Health 59, 619-27 (2005).

84. Shaw, R. J. et al. Impact of ethnic density on adult mental disorders: narrative review. Br. J. Psychiatry 201, 11-9 (2012).

85. Veling, W., Hoek, H. W., Wiersma, D. \& Mackenbach, J. P. Ethnic identity and the risk of schizophrenia in ethnic minorities: a case-control study. Schizophr. Bull. 36, 1149-56 (2010).

86. Tortelli, A. et al. Schizophrenia and other psychotic disorders in Caribbean-born migrants and their descendants in England: systematic review and meta-analysis of incidence rates, 19502013. Soc. Psychiatry Psychiatr. Epidemiol. 50, 1039-55 (2015).

87. Morgan, C., Charalambides, M., Hutchinson, G. \& Murray, R. M. Migration, ethnicity, and psychosis: toward a sociodevelopmental model. Schizophr. Bull. 36, 655-64 (2010).

88. Myin-Germeys, I., Krabbendam, L., Delespaul, P. A. E. G. \& Van Os, J. Do life events have their effect on psychosis by influencing the emotional reactivity to daily life stress? Psychol. Med. 33, 327-333 (2003).

89. Read, J., van Os, J., Morrison, A. P. \& Ross, C. A. Childhood trauma, psychosis and schizophrenia: a literature review with theoretical and clinical implications. Acta Psychiatr. Scand. 112, 33050 (2005). 
90. Norman, R. M. \& Malla, A. K. Stressful life events and schizophrenia. I: A review of the research. Br. J. Psychiatry 162, 161-166 (1993).

91. Løberg, E.-M. et al. The Cannabis Pathway to Non-Affective Psychosis may Reflect Less Neurobiological Vulnerability. Front. psychiatry 5, 159 (2014).

92. D'Souza, D. C., Sewell, R. A. \& Ranganathan, M. Cannabis and psychosis/schizophrenia: human studies. Eur. Arch. Psychiatry Clin. Neurosci. 259, 413-31 (2009).

93. Craddock, N., O'Donovan, M. C. \& Owen, M. J. The genetics of schizophrenia and bipolar disorder: dissecting psychosis. J. Med. Genet. 42, 193-204 (2005).

94. Blackwood, D. H. R. et al. Are some genetic risk factors common to schizophrenia, bipolar disorder and depression? Evidence from DISC1, GRIK4 and NRG1. Neurotox. Res. 11, 73-83 (2007).

95. Mortensen, P. B., Pedersen, C. B., Melbye, M., Mors, O. \& Ewald, H. Individual and familial risk factors for bipolar affective disorders in Denmark. Arch. Gen. Psychiatry 60, 1209-15 (2003).

96. Pedersen, C. B. \& Mortensen, P. B. Urbanicity during upbringing and bipolar affective disorders in Denmark. Bipolar Disord. 8, 242-7 (2006).

97. Kirkbride, J. B. et al. Neighbourhood variation in the incidence of psychotic disorders in Southeast London. Soc. Psychiatry Psychiatr. Epidemiol. 42, 438-45 (2007).

98. Oher, F. J. et al. The effect of the environment on symptom dimensions in the first episode of psychosis: a multilevel study. Psychol. Med. FirstView, 1-12 (2014).

99. Goldberg, E. M. \& Morrison, S. L. Schizophrenia and social class. Br. J. Psychiatry 109, 785-802 (1963).

100. Ngamini Ngui, A. et al. Does elapsed time between first diagnosis of schizophrenia and migration between health territories vary by place of residence? A survival analysis approach. Health Place 20, 66-74 (2013).

101. Kirkbride, J. B. et al. Social and spatial heterogeneity in psychosis proneness in a multilevel case-prodrome-control study. Acta Psychiatr. Scand. 132, 283-292 (2015).

102. van Os, J., Krabbendam, L., Myin-Germeys, I. \& Delespaul, P. The schizophrenia envirome. Curr Opin Psychiatry 18, 141-145 (2005).

103. Bleuler, E. Dementia praecox or the group of schizophrenias. (1911).

104. Mednick, S. A. Breakdown in individuals at high risk for schizophrenia: Possible predispositional perinatal factors. Ment. Hyg. 54, 50-63 (1970).

105. Lane, E. A. \& Albee, G. W. Comparative Birth Weights of Schizophrenics and Their Siblings. J. Psychol. 64, 227-231 (1966).

106. Lewis, S. W. \& Murray, R. M. Obstetric complications, neurodevelopmental deviance, and risk of schizophrenia. J. Psychiatr. Res. 21, 413-421 (1987).

107. Mizrahi, R. Social Stress and Psychosis Risk: Common Neurochemical Substrates? Neuropsychopharmacology 41, 666-74 (2016).

108. Akdeniz, C., Tost, H. \& Meyer-Lindenberg, A. The neurobiology of social environmental risk for schizophrenia: an evolving research field. Soc. Psychiatry Psychiatr. Epidemiol. 49, 507-17 (2014).

109. Veling, W., Pot-Kolder, R., Counotte, J., van Os, J. \& van der Gaag, M. Environmental Social Stress, Paranoia and Psychosis Liability: A Virtual Reality Study. Schizophr. Bull. sbw031(2016). doi:10.1093/schbul/sbw031

110. Tost, H., Champagne, F. A. \& Meyer-Lindenberg, A. Environmental influence in the brain, human welfare and mental health. Nat. Neurosci. 18, 1421-31 (2015).

111. Selten, J.-P. \& Cantor-Graae, E. Social defeat: risk factor for schizophrenia? Br. J. Psychiatry 187, 101-2 (2005).

112. Selten, J.-P. \& Cantor-Graae, E. Hypothesis: social defeat is a risk factor for schizophrenia? Br. J. Psychiatry. Suppl. 51, s9-12 (2007).

113. Selten, J.-P., van der Ven, E., Rutten, B. P. F. \& Cantor-Graae, E. The social defeat hypothesis of schizophrenia: an update. Schizophr. Bull. 39, 1180-6 (2013). 
114. van Os, J. \& McGuffin, P. Can the social environment cause schizophrenia? Br. J. Psychiatry 182, 291-292 (2003).

115. Kirkbride, J. B. \& Jones, P. B. in Migration and mental health (eds. Bughra, D. \& Gupta, S.) 1531 (Cambridge University Press, 2011).

116. van Os, J. et al. Identifying gene-environment interactions in schizophrenia: contemporary challenges for integrated, large-scale investigations. Schizophr. Bull. 40, 729-36 (2014).

117. Kirkbride, J. B. et al. Examining evidence for neighbourhood variation in the duration of untreated psychosis. Health Place 16, 219-25 (2010).

118. Steel, Z. et al. The global prevalence of common mental disorders: a systematic review and meta-analysis 1980-2013. Int. J. Epidemiol. 43, 476-93 (2014).

119. Lewis, G. \& Booth, M. Are cities bad for your mental health? Psychol. Med. 24, 913-915 (1994).

120. Paykel, E. S., Abbott, R., Jenkins, R., Brugha, T. S. \& Meltzer, H. Urban-rural mental health differences in great Britain: findings from the national morbidity survey. Psychol. Med. 30, 26980 (2000).

121. Weich, S., Twigg, L. \& Lewis, G. Rural/non-rural differences in rates of common mental disorders in Britain: prospective multilevel cohort study. Br. J. Psychiatry 188, 51-7 (2006).

122. de Graaf, R., ten Have, M., Tuithof, M. \& van Dorsselaer, S. First-incidence of DSM-IV mood, anxiety and substance use disorders and its determinants: Results from the Netherlands Mental Health Survey and Incidence Study-2. J. Affect. Disord. 149, 100-107 (2013).

123. de Graaf, R., ten Have, M., van Gool, C. \& van Dorsselaer, S. Prevalence of mental disorders and trends from 1996 to 2009. Results from the Netherlands Mental Health Survey and Incidence Study-2. Soc. Psychiatry Psychiatr. Epidemiol. 47, 203-13 (2012).

124. de Graaf, R., Bijl, R. V., Ravelli, A., Smit, F. \& Vollebergh, W. A. M. Predictors of first incidence of DSM-III-R psychiatric disorders in the general population: findings from the Netherlands Mental Health Survey and Incidence Study. Acta Psychiatr. Scand. 106, 303-313 (2002).

125. Kovess-Masfety, V., Lecoutour, X. \& Delavelle, S. Mood disorders and urban/rural settings: comparisons between two French regions. Soc. Psychiatry Psychiatr. Epidemiol. 40, 613-8 (2005).

126. Ayuso-Mateos, J.-L. Depressive disorders in Europe: prevalence figures from the ODIN study. Br. J. Psychiatry 179, 308-316 (2001).

127. Parikh, S. V., Wasylenki, D., Goering, P. \& Wong, J. Mood disorders: rural/urban differences in prevalence, health care utilization, and disability in Ontario. J. Affect. Disord. 38, 57-65 (1996).

128. Romans, S., Cohen, M. \& Forte, T. Rates of depression and anxiety in urban and rural Canada. Soc. Psychiatry Psychiatr. Epidemiol. 46, 567-75 (2011).

129. Patten, S. B. et al. Descriptive Epidemiology of Major Depression in Canada. Can. J. Psychiatry. 51, 84-90 (2006).

130. Wang, J. L. Rural-urban differences in the prevalence of major depression and associated impairment. Soc. Psychiatry Psychiatr. Epidemiol. 39, 19-25 (2004).

131. Kessler, R. C. et al. Lifetime and 12-month prevalence of DSM-III-R psychiatric disorders in the United States. Results from the National Comorbidity Survey. Arch. Gen. Psychiatry 51, 8-19 (1994).

132. Blazer, D. G., Kessler, R. C., McGonagle, K. A. \& Swartz, M. S. The prevalence and distribution of major depression in a national community sample: the National Comorbidity Survey. Am. J. Psychiatry 151, 979-86 (1994).

133. Kessler, R. C. et al. The epidemiology of major depressive disorder: results from the National Comorbidity Survey Replication (NCS-R). JAMA 289, 3095-105 (2003).

134. Probst, J. C. et al. Rural-urban differences in depression prevalence: implications for family medicine. Fam. Med. 38, 653-60 (2006).

135. Grant, B. F. et al. Sociodemographic and psychopathologic predictors of first incidence of DSMIV substance use, mood and anxiety disorders: results from the Wave 2 National Epidemiologic Survey on Alcohol and Related Conditions. Mol. Psychiatry 14, 1051-66 (2009). 
136. Beyer, K. M. M. et al. Exposure to neighborhood green space and mental health: evidence from the survey of the health of Wisconsin. Int. J. Environ. Res. Public Health 11, 3453-72 (2014).

137. Andrews, G. Prevalence, comorbidity, disability and service utilisation: Overview of the Australian National Mental Health Survey. Br. J. Psychiatry 178, 145-153 (2001).

138. Andrade, L. et al. The epidemiology of major depressive episodes: results from the International Consortium of Psychiatric Epidemiology (ICPE) surveys. Int. J. Methods Psychiatr. Res. 12, 3-21 (2003).

139. Mohammadi, M.-R. et al. An epidemiological survey of psychiatric disorders in Iran. Clin. Pract. Epidemiol. Ment. Health 1, 16 (2005).

140. Amoran, O., Lawoyin, T. \& Lasebikan, V. Prevalence of depression among adults in Oyo State, Nigeria: a comparative study of rural and urban communities. Aust. J. Rural Health 15, 211-5 (2007).

141. Probst, J. C. et al. Rural-urban differences in depression prevalence: implications for family medicine. Fam. Med. 38, 653-60 (2006).

142. Andrews, G. Prevalence, comorbidity, disability and service utilisation: Overview of the Australian National Mental Health Survey. Br. J. Psychiatry 178, 145-153 (2001).

143. Guite, H. F., Clark, C. \& Ackrill, G. The impact of the physical and urban environment on mental well-being. Public Health 120, 1117-26 (2006).

144. Weich, S. et al. Mental health and the built environment: cross-sectional survey of individual and contextual risk factors for depression. Br. J. Psychiatry 180, 428-33 (2002).

145. Weich, S. Contextual risk factors for the common mental disorders in Britain: a multilevel investigation of the effects of place. J. Epidemiol. Community Heal. 57, 616-621 (2003).

146. Weich, S. Geographic Variation in the Prevalence of Common Mental Disorders in Britain: A Multilevel Investigation. Am. J. Epidemiol. 157, 730-737 (2003).

147. Weich, S., Twigg, L., Lewis, G. \& Jones, K. Geographical variation in rates of common mental disorders in Britain: prospective cohort study. Br. J. Psychiatry 187, 29-34 (2005).

148. Stafford, M. \& Marmot, M. Neighbourhood deprivation and health: does it affect us all equally? Int. J. Epidemiol. 32, 357-366 (2003).

149. Stafford, M., De Silva, M., Stansfeld, S. \& Marmot, M. Neighbourhood social capital and common mental disorder: testing the link in a general population sample. Health Place 14, 394405 (2008).

150. Halpern, D. \& Nazroo, J. The ethnic density effect: results from a national community survey of England and Wales. Int. J. Soc. Psychiatry 46, 34-46 (2000).

151. McCulloch, A. Ward-Level Deprivation and Individual Social and Economic Outcomes in the British Household Panel Study. Environ. Plan. A 33, 667-684 (2001).

152. Wainwright, N. W. J. \& Surtees, P. G. Area and individual circumstances and mood disorder prevalence. Br. J. Psychiatry 185, 227-32 (2004).

153. Skapinakis, P., Lewis, G., Araya, R., Jones, K. \& Williams, G. Mental health inequalities in Wales, UK: multi-level investigation of the effect of area deprivation. Br. J. Psychiatry 186, 417-22 (2005).

154. Fone, D. L. \& Dunstan, F. Mental health, places and people: a multilevel analysis of economic inactivity and social deprivation. Health Place 12, 332-44 (2006).

155. Reijneveld, S. A. \& Schene, A. H. Higher prevalence of mental disorders in socioeconomically deprived urban areas in The Netherlands: community or personal disadvantage? J. Epidemiol. Community Heal. 52, 2-7 (1998).

156. Erdem, Ö., Prins, R. G., Voorham, T. A. J. J., van Lenthe, F. J. \& Burdorf, A. Structural neighbourhood conditions, social cohesion and psychological distress in the Netherlands. Eur. J. Public Health ckv120 (2015). doi:10.1093/eurpub/ckv120

157. Lofors, J., Ramírez-León, V. \& Sundquist, K. Neighbourhood income and anxiety: a study based on random samples of the Swedish population. Eur. J. Public Health 16, 633-9 (2006).

158. Vallée, J., Cadot, E., Roustit, C., Parizot, I. \& Chauvin, P. The role of daily mobility in mental 
health inequalities: the interactive influence of activity space and neighbourhood of residence on depression. Soc. Sci. Med. 73, 1133-44 (2011).

159. Jones-Rounds, M. L., Evans, G. W. \& Braubach, M. The interactive effects of housing and neighbourhood quality on psychological well-being. J. Epidemiol. Community Health $68,171-5$ (2014).

160. Tweed, D. L. et al. Racial congruity as a contextual correlate of mental disorder. Am. J. Orthopsychiatry 60, 392-403 (1990).

161. Yen, I. \& Kaplan, G. Poverty area residence and changes in depression and perceived health status: evidence from the Alameda County Study. Int. J. Epidemiol. 28, 90-94 (1999).

162. Ross, C. E., Reynolds, J. R. \& Geis, K. J. The contingent meaning of neighborhood stability for residents' psychological well-being. Am. Sociol. Rev. 65, 581-597 (2000).

163. Stockdale, S. E. et al. The importance of social context: neighborhood stressors, stressbuffering mechanisms, and alcohol, drug, and mental health disorders. Soc. Sci. Med. 65, 186781 (2007).

164. Leventhal, T. \& Brooks-Gunn, J. Moving to opportunity: an experimental study of neighborhood effects on mental health. Am. J. Public Health 93, 1576-82 (2003).

165. Greiner, K. A., Li, C., Kawachi, I., Hunt, D. C. \& Ahluwalia, J. S. The relationships of social participation and community ratings to health and health behaviors in areas with high and low population density. Soc. Sci. Med. 59, 2303-12 (2004).

166. Galea, S., Ahern, J., Rudenstine, S., Wallace, Z. \& Vlahov, D. Urban built environment and depression: a multilevel analysis. J Epidemiol Community Heal. 59, 822-827 (2005).

167. Dupéré, V. \& Perkins, D. D. Community types and mental health: a multilevel study of local environmental stress and coping. Am. J. Community Psychol. 39, 107-19 (2007).

168. Galea, S. et al. Urban neighborhood poverty and the incidence of depression in a populationbased cohort study. Ann. Epidemiol. 17, 171-9 (2007).

169. Ahern, J. \& Galea, S. Collective efficacy and major depression in urban neighborhoods. Am. J. Epidemiol. 173, 1453-62 (2011).

170. Matheson, F. I. et al. Urban neighborhoods, chronic stress, gender and depression. Soc. Sci. Med. 63, 2604-16 (2006).

171. Gariepy, G. et al. The Neighbourhood Built Environment and Trajectories of Depression Symptom Episodes in Adults: A Latent Class Growth Analysis. PLoS One 10, e0133603 (2015).

172. Veenstra, G. Location, location, location: contextual and compositional health effects of social capital in British Columbia, Canada. Soc. Sci. Med. 60, 2059-71 (2005).

173. Jokela, M. Are neighborhood health associations causal? A 10-year prospective cohort study with repeated measurements. Am. J. Epidemiol. 180, 776-84 (2014).

174. Chiavegatto Filho, A. D. P., Kawachi, I., Wang, Y. P., Viana, M. C. \& Andrade, L. H. S. G. Does income inequality get under the skin? A multilevel analysis of depression, anxiety and mental disorders in Sao Paulo, Brazil. J. Epidemiol. Community Health 67, 966-72 (2013).

175. Tomita, A. \& Burns, J. K. A multilevel analysis of association between neighborhood social capital and depression: evidence from the first South African National Income Dynamics Study. J. Affect. Disord. 144, 101-5 (2013).

176. Propper, C. et al. Local neighbourhood and mental health: evidence from the UK. Soc. Sci. Med. 61, 2065-83 (2005).

177. Galea, S., Ahern, J., Rudenstine, S., Wallace, Z. \& Vlahov, D. Urban built environment and depression: a multilevel analysis. J. Epidemiol. Community Health 59, 822-7 (2005).

178. Das-Munshi, J., Becares, L., Dewey, M. E., Stansfeld, S. A. \& Prince, M. J. Understanding the effect of ethnic density on mental health: multi-level investigation of survey data from England. BMJ 341, c5367 (2010).

179. Ahern, J. \& Galea, S. Collective efficacy and major depression in urban neighborhoods. Am. J. Epidemiol. 173, 1453-62 (2011).

180. Amoran, O., Lawoyin, T. \& Lasebikan, V. Prevalence of depression among adults in Oyo State, 
Nigeria: a comparative study of rural and urban communities. Aust. J. Rural Health 15, 211-5 (2007).

181. World Health Organization. Preventing suicide: A global imperative. (2014).

182. Shiner, M., Scourfield, J., Fincham, B. \& Langer, S. When things fall apart: Gender and suicide across the life-course. Soc. Sci. Med. 69, 738-46 (2009).

183. Langhinrichsen-Rohling, J., Friend, J. \& Powell, A. Adolescent suicide, gender, and culture: A rate and risk factor analysis. Aggress. Violent Behav. 14, 402-414 (2009).

184. von Borczyskowski, A., Lindblad, F., Vinnerljung, B. \& Hjern, A. Gender differences in risk factors for suicide: findings from a Swedish national cohort study. Can. J. Psychiatry. 55, 108-11 (2010).

185. Gibb, S. J., Beautrais, A. L. \& Fergusson, D. M. Mortality and further suicidal behaviour after an index suicide attempt: a 10-year study. Aust. N. Z. J. Psychiatry 39, 95-100 (2004).

186. Hawton, K. Sex and suicide. Gender differences in suicidal behaviour. Br. J. Psychiatry 177, 4845 (2000).

187. Beautrais, A. Risk factors for suicide and attempted suicide among young people. Aust. N. Z. J. Psychiatry 34, 420-436 (2000).

188. Arsenault-Lapierre, G., Kim, C. \& Turecki, G. Psychiatric diagnoses in 3275 suicides: a metaanalysis. BMC Psychiatry 4, 37 (2004).

189. Beskow, J. Suicide in mental disorder in Swedish men. Acta Psychiatr. Scand. 277, (1979).

190. Qin, P., Hawton, K., Mortensen, P. B. \& Webb, R. Combined effects of physical illness and comorbid psychiatric disorder on risk of suicide in a national population study. Br. J. Psychiatry (2014). doi:10.1192/bjp.bp.113.128785

191. Page, A., Milner, A., Morrell, S. \& Taylor, R. The role of under-employment and unemployment in recent birth cohort effects in Australian suicide. Soc. Sci. Med. 93, 155-62 (2013).

192. Winfree Jr, T. \& Jiang, S. Youthful Suicide and Social Support: Exploring the Social Dynamics of Suicide-Related Behavior and Attitudes Within a National Sample of US Adolescents. Youth Violence Juv. Justice 8, 19-37 (2010).

193. Kunst, A. E., van Hooijdonk, C., Droomers, M. \& Mackenbach, J. P. Community social capital and suicide mortality in the Netherlands: a cross-sectional registry-based study. BMC Public Health 13, 969 (2013).

194. Fergusson, D. M., Horwood, L. J., Ridder, E. M. \& Beautrais, A. L. Suicidal behaviour in adolescence and subsequent mental health outcomes in young adulthood. Psychol. Med. 35, 983-993 (2005).

195. Fergusson, D. M. \& Lynskey, M. T. Suicide attempts and suicidal ideation in a birth cohort of 16-year-old New Zealanders. J. Am. Acad. Child Adolesc. Psychiatry 34, 1308-17 (1995).

196. Zapata, L. B. et al. Orphaned and abused youth are vulnerable to pregnancy and suicide risk. Child Abuse Negl. 37, 310-9 (2013).

197. Rajalin, M., Hirvikoski, T. \& Jokinen, J. Family history of suicide and exposure to interpersonal violence in childhood predict suicide in male suicide attempters. J. Affect. Disord. 148, 92-7 (2013).

198. Pompili, M. et al. Substance abuse, temperament and suicide risk: evidence from a case-control study. J. Addict. Dis. 28, 13-20 (2009).

199. Durkheim, E. On suicide. (Penguin Books, 1897).

200. Tarde, G. The laws of imitation. (Henry Holt, 1903).

201. Caldwell, T. M., Jorm, A. F. \& Dear, K. B. G. Suicide and mental health in rural, remote and metropolitan areas in Australia. Med. J. Aust. 181, 10-14 (2004).

202. Tak, Y. et al. Spatial analysis of suicide mortality in Australia : Investigation of metropolitanrural-remote differentials of suicide risk across states/territories. Soc. Sci. Med. 75, 1460-1468 (2012).

203. Snider, C. L. A. \& Leo, D. De. The influence of deprivation on suicide mortality in urban and rural Queensland : an ecological analysis. 1919-1928 (2014). doi:10.1007/s00127-014-0905-1

204. Page, A., Morrell, S., Taylor, R., Dudley, M. \& Carter, G. Further increases in rural suicide in 
young Australian adults: secular trends, 1979-2003. Soc. Sci. Med. 65, 442-453 (2007).

205. Qi, X., Hu, W., Page, A. \& Tong, S. Dynamic pattern of suicide in Australia, 1986-2005: a descriptive-analytic study. BMJ Open 4, e005311 (2014).

206. Wilkinson, D. \& Gunnell, D. Youth suicide trends in Australian metropolitan and nonmetropolitan areas, 1988-1997. Aust. N. Z. J. Psychiatry 34, 822-828 (2000).

207. Fontanella, C. A. et al. Widening Rural-Urban Disparities in Youth Suicides, United States, 19962010. JAMA Pediatr. 169, 466 (2015).

208. Hempstead, K. The geography of self-injury: Spatial patterns in attempted and completed suicide. Soc. Sci. Med. 62, 3186-3196 (2006).

209. Searles, V. B., Valley, M. a, Hedegaard, H. \& Betz, M. E. Suicides in urban and rural counties in the United States, 2006-2008. Crisis 35, 18-26 (2014).

210. Singh, G. K. \& Siahpush, M. Increasing Rural-Urban Gradients in US Suicide Mortality, 19701997. Am. J. Public Health 92, 1161-1167 (2002).

211. Kapusta, N. D. et al. Rural-urban differences in Austrian suicides. Soc. Psychiatry Psychiatr. Epidemiol. 43, 311-318 (2008).

212. Kapusta, N. D. et al. Availability of mental health service providers and suicide rates in Austria: a nationwide study. Psychiatr. Serv. 61, 1198-1203 (2010).

213. Stark, C., Hopkins, P., Gibbs, D., Belbin, A. \& Hay, A. Population density and suicide in Scotland. Rural Remote Health 7, (2007).

214. Levin, K. A. \& Leyland, A. H. Urban/rural inequalities in suicide in Scotland, 1981-1999. Soc. Sci. Med. 60, 2877-2890 (2005).

215. Middleton, N., Gunnell, D., Frankel, S., Whitley, E. \& Dorling, D. Urban-rural differences in suicide trends in young adults: England and Wales, 1981-1998. Soc. Sci. Med. 57, 1183-1194 (2003).

216. Ngamini Ngui, A. et al. Disentangling the influence of neighborhood and individual characteristics on early residential mobility among newly diagnosed patients with schizophrenia: a multilevel analysis. Soc. Psychiatry Psychiatr. Epidemiol. 49, 1569-78 (2014).

217. Pearce, J., Barnett, R. \& Jones, I. Have urban/rural inequalities in suicide in New Zealand grown during the period 1980-2001? Soc. Sci. Med. 65, 1807-1819 (2007).

218. Chang, S. S. et al. Geography of suicide in Taiwan: spatial patterning and socioeconomic correlates. Health Place 17, 641-650 (2011).

219. Patel, V. et al. Suicide mortality in India: A nationally representative survey. Lancet 379, 23432351 (2012).

220. Razvodovsky, Y. \& Stickley, A. Suicide in urban and rural regions of Belarus, 1990-2005. Public Health 123, 27-31 (2009).

221. Yip, P. S. F., Callanan, C. \& Yuen, H. P. Urban/rural and gender differentials in suicide rates: East and West. J. Affect. Disord. 57, 99-106 (2000).

222. Park, B. \& Lester, D. Rural and urban suicide in South Korea. Psychol. Rep. 111, 495-497 (2012).

223. Ngamini Ngui, A., Apparicio, P., Moltchanova, E. \& Vasiliadis, H.-M. Spatial analysis of suicide mortality in Québec: spatial clustering and area factor correlates. Psychiatry Res. 220, 20-30 (2014).

224. Titelman, D. et al. Suicide mortality trends in the Nordic countries 1980-2009. Nord. J. Psychiatry 67, 414-23 (2013).

225. Yip, P. S. F., Liu, K. Y., Hu, J. \& Song, X. M. Suicide rates in China during a decade of rapid social changes. Soc. Psychiatry Psychiatr. Epidemiol. 40, 792-798 (2005).

226. Middleton, N., Sterne, J. A. C. \& Gunnell, D. J. An atlas of suicide mortality: England and Wales, 1988-1994. Heal. Place 14, 492-506 (2008).

227. Taylor, R., Page, A., Morrell, S., Harrison, J. \& Carter, G. Social and Psychiatric Influences on Urban-Rural Differentials in Australian Suicide. Suicide Life-Threatening Behav. 35, 277-290 (2005).

228. Linsley, K. R., Schapira, K. \& Kelly, T. P. Open verdict v. suicide - Importance to research. Br. J. 
Psychiatry 178, 465-468 (2001).

229. Palmer, B. S. et al. Factors influencing coroners' verdicts: An analysis of verdicts given in 12 coroners' districts to researcher-defined suicides in England in 2005. J. Public Heal. (United Kingdom) 37, 157-165 (2015).

230. Hooghe, M. \& Vanhoutte, B. An ecological study of community-level correlates of suicide mortality rates in the Flemish region of Belgium, 1996-2005. Suicide Life. Threat. Behav. 41, 453-64 (2011).

231. Agerbo, E., Sterne, J. a C. \& Gunnell, D. J. Combining individual and ecological data to determine compositional and contextual socio-economic risk factors for suicide. Soc. Sci. Med. 64, 45161 (2007).

232. Qi, X., Tong, S. \& Hu, W. Spatial distribution of suicide in Queensland, Australia. BMC Psychiatry 10, 106 (2010).

233. Collings, S., Ivory, V., Blakely, T. \& Atkinson, J. Are neighbourhood social fragmentation and suicide associated in New Zealand? A national multilevel cohort study. J. Epidemiol. Community Health 63, 1035-1042 (2009).

234. Congdon, P. Latent variable model for suicide risk in relation to social capital and socioeconomic status. Soc. Psychiatry Psychiatr. Epidemiol. 47, 1205-19 (2012).

235. Neeleman, J. \& Wessely, S. Ethnic minority suicide: a small area geographical study in south London. Psychol. Med. 29, 429-36 (1999).

236. O'Reilly, D. O., Rosato, M., Connolly, S. \& Cardwell, C. Area factors and suicide: 5-year followup of the Northern Ireland population. Br. J. Psychiatry 192, 106-11 (2008).

237. Whitley, E., Gunnell, D., Dorling, D. \& Smith, G. D. Ecological study of social fragmentation, poverty, and suicide. BMJ 319, 1034-7 (1999).

238. Haws, C. A. et al. The possible effect of altitude on regional variation in suicide rates. Med. Hypotheses 73, 587-590 (2009).

239. Martikainen, P., Mäki, N. \& Blomgren, J. The Effects of Area and Individual Social Characteristics on Suicide Risk: A Multilevel Study of Relative Contribution and Effect Modification. Eur. J. Popul. 20, 323-350 (2004).

240. Kelly, B. D. \& Davoren, $\mathbb{E}$. M. Social capital and suicide in 11 European countries : an ecological analysis. 971-977 (2009). doi:10.1007/s00127-009-0018-4

241. Tsai, J. F. Socioeconomic factors outweigh climate in the regional difference of suicide death rate in Taiwan. Psychiatry Res. 179, 212-216 (2010).

242. Bando, D. H., Brunoni, A. R., Benseñor, I. M. \& Lotufo, P. a. Suicide rates and income in São Paulo and Brazil: a temporal and spatial epidemiologic analysis from 1996 to 2008. BMC Psychiatry 12, 127 (2012).

243. Jagodic, H. K., Rokavec, T., Agius, M. \& Pregelij, P. Availability of mental health service providers and suicide rates in Slovenia: A nationwide ecological study. Croat Med J 54, 1198-1203 (2013).

244. Okamoto, M., Kawakami, N., Kido, Y. \& Sakurai, K. Social capital and suicide: An ecological study in Tokyo, Japan. Environ. Health Prev. Med. 18, 306-312 (2013).

245. Rehkopf, D. H. \& Buka, S. L. The association between suicide and the socio-economic characteristics of geographical areas: a systematic review. Psychol. Med. 36, 145 (2005).

246. Kelly, B. D., Davoren, M., Mhaoláin, A. N., Breen, E. G. \& Casey, P. Social capital and suicide in 11 European countries: an ecological analysis. Soc. Psychiatry Psychiatr. Epidemiol. 44, 971-7 (2009).

247. Zammit, S. et al. Individual- and area-level influence on suicide risk: a multilevel longitudinal study of Swedish schoolchildren. Psychol. Med. 44, 267-77 (2014).

248. Zhang, J. \& Wang, C. Factors in the neighborhood as risks of suicide in rural China: a multilevel analysis. Community Ment. Health J. 48, 627-33 (2012).

249. Macintyre, S. \& Ellaway, A. in Neighbourhoods and health (eds. Kawachi, I. \& Berkman, L.) 2043 (Oxford University Press, 2003).

250. Crawford, M. J., Kuforiji, B. \& Ghosh, P. The impact of social context on socio-demographic risk 
factors for suicide: a synthesis of data from case-control studies. J. Epidemiol. Community Health 64, 530-4 (2010).

251. Judd, F., Cooper, A. M., Fraser, C. \& Davis, J. Rural suicide - People or place effects? Aust. N. Z. J. Psychiatry 40, 208-216 (2006).

252. Hirsch, J. K. \& Cukrowicz, K. C. Suicide in rural areas: An updated review of the literature. J. Rural Ment. Heal. 38, 65-78 (2014).

253. Rodríguez Andrés, A. \& Hempstead, K. Gun control and suicide: the impact of state firearm regulations in the United States, 1995-2004. Health Policy 101, 95-103 (2011).

254. Park, S. et al. Increased use of lethal methods and annual increase of suicide rates in Korean adolescents: Comparison with adolescents in the United States. J. Child Psychol. Psychiatry Allied Discip. 55, 258-263 (2014).

255. Large, M. M. \& Nielssen, O. B. Suicide in Australia: Meta-analysis of rates and methods of suicide between 1988 and 2007. Med. J. Aust. 192, 432-437 (2010).

256. Alston, M. Rural male suicide in Australia. Soc. Sci. Med. 74, 515-522 (2012).

257. Hirsch, J. K. A review of the literature on rural suicide: risk and protective factors, incidence, and prevention. Crisis 27, 189-199 (2006). 